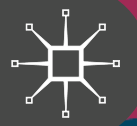

\title{
O Open Access
}

\section{palgraverpivot}

\section{Forensic Genetics in the Governance of Crime}

\section{Helena Machado Rafaela Granja}


Forensic Genetics in the Governance of Crime 
Helena Machado • Rafaela Granja

Forensic Genetics in the Governance of Crime

palgrave macmillan 
Helena Machado

Communication and Society Research

Centre (CECS)

University of Minho

Braga, Portugal
Rafaela Granja

Communication and Society Research

Centre (CECS)

University of Minho

Braga, Portugal

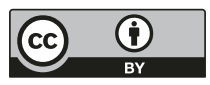

ISBN 978-981-15-2428-8 ISBN 978-981-15-2429-5 (eBook) https://doi.org/10.1007/978-981-15-2429-5

(C) The Editor(s) (if applicable) and The Author(s) 2020 This book is an open access publication.

Open Access This book is licensed under the terms of the Creative Commons Attribution 4.0 International License (http://creativecommons.org/licenses/by/4.0/), which permits use, sharing, adaptation, distribution and reproduction in any medium or format, as long as you give appropriate credit to the original author(s) and the source, provide a link to the Creative Commons licence and indicate if changes were made.

The images or other third party material in this book are included in the book's Creative Commons licence, unless indicated otherwise in a credit line to the material. If material is not included in the book's Creative Commons licence and your intended use is not permitted by statutory regulation or exceeds the permitted use, you will need to obtain permission directly from the copyright holder.

The use of general descriptive names, registered names, trademarks, service marks, etc. in this publication does not imply, even in the absence of a specific statement, that such names are exempt from the relevant protective laws and regulations and therefore free for general use. The publisher, the authors and the editors are safe to assume that the advice and information in this book are believed to be true and accurate at the date of publication. Neither the publisher nor the authors or the editors give a warranty, expressed or implied, with respect to the material contained herein or for any errors or omissions that may have been made. The publisher remains neutral with regard to jurisdictional claims in published maps and institutional affiliations.

\section{Cover Pattern: @ Melisa Hasan}

This Palgrave Pivot imprint is published by the registered company Springer Nature Singapore Pte Ltd.

The registered company address is: 152 Beach Road, \#21-01/04 Gateway East, Singapore 189721, Singapore 


\section{ACKNOWLEDGEMENTS}
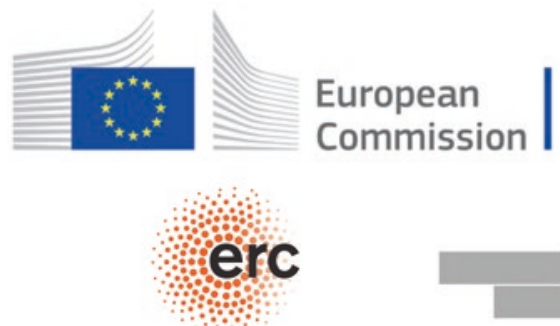

European Research Council

This work has received funding from the European Research Council (ERC) under the European Union's Horizon 2020 research and innovation programme (grant agreement no. 648608), within the project "EXCHANGE-Forensic geneticists and the transnational exchange of DNA data in the EU: Engaging science with social control, citizenship and democracy" led by Helena Machado and hosted at the Communication and Society Research Centre, Institute for Social Sciences of University of Minho, Portugal. 


\section{Contents}

1 Introduction 1

2 The Sociological Gaze 13

3 Biological Explanations of Criminal Behaviour 33

4 DNA Technologies in Criminal Investigation and Courts 45

5 DNA Databases and Big Data 57

6 Forensic Genetics and Governance of Transnational Criminality

7 Emerging DNA Technologies and Stigmatization 85

8 Conclusion 105

$\begin{array}{ll}\text { Glossary } & 113\end{array}$ 


\section{List OF TABLES}

Table 2.1 Paradigms of sociological thought

15

Table 5.1 Size of several forensic genetic databases in Europe 


\title{
Introduction
}

\begin{abstract}
The introductory chapter offers a detailed description of the themes that the reader can expect to find in this book, and a discussion of the social and academic relevance of the role and use of forensic genetic technologies in the criminal justice system. This introductory chapter provides the key concepts for the discussion of how developments in the application of forensic genetics can be understood as part of wider shifts in how the governance of criminality is enacted and made visible through the symbolic power invested in science and technology.
\end{abstract}

Keywords Governance of crime $\bullet$ Forensic genetics $\bullet$ DNA

\section{The Role of Genetics in Crime Governance}

Wherever it goes, the human body leaves traces behind: hair, saliva and other fluids, footprints and so on. Body's materiality has been a key part of criminal investigations throughout history. The central role of the human body as the basis to identify authors of crimes has gained different shapes in the last 35 years, as forensic science became more commonplace in criminal justice systems.

Forensic science comprises a set of scientific disciplines and methodologies, whose goal is to help police-judicial procedures and activities. Among others, we can mention forensic toxicology, psychiatry and forensic psychology, anthropology and forensic odontology, criminalistics, biology and forensic genetics. This book will pay special attention to the last scien-

(C) The Author(s) 2020

H. Machado, R. Granja, Forensic Genetics in the Governance of

Crime, https://doi.org/10.1007/978-981-15-2429-5_1 
tific discipline. Forensic genetics aims to identify with the greatest possible precision the biological origin of a sample, to help the justice system address and solve civil and criminal cases.

One of the most notable aspects of the use of forensic genetics in the field of criminal investigation is the ability to extract DNA profiles-a biological structure considered unique for every individual-from the samples collected at crime scenes or obtained from the bodies of people identified in the criminal investigation (e.g., suspects). This genetic information, if considered relevant by the professionals involved in the specific criminal investigation, may produce genetic evidence, which will subsequently be assessed in a court of criminal justice. This book proposes a sociological approach to the role and place of forensic genetics in the governance of crime in contemporary societies.

The concept governance of crime intends to highlight assumptions, discourses and strategies that shape this social sphere. The governance of crime encapsulates more than the social response to crime. It also incorporates new ways to monitor and control behaviours, as well as reconfigured forms to apply justice, which co-construct new concepts of order and social control (Garland, 2001). The concept of governance of crime will be, therefore, used throughout this book to show how the strategies applied to social groups considered as risky have gained a more managerial and less transformative tone (Feeley \& Simon, 1992). We will frame in this context the growing, more expansive way that biometric technologies, in particular forensic genetics, have been applied to strategies pertaining to the governance of crime. By collecting, storing, exchanging and using genetic data on a large scale, new systems of social sorting are promoted and instituted (Lyon, 2002). These technological systems do not just act upon individuals, they create growingly elaborate ways, in terms of impact and reach, to monitor and control particular individuals and specific social groups. Finally, this concept also makes it possible to look beyond the way State structures govern current societies, in order to include other social institutions that also constitute the backbone of the governance of crime in contemporary societies. Such is the case of the networks producing scientific knowledge, making visible the symbolic power invested in science and technology. This also extends to non-governmental organizations, private companies, media, civil society and many others.

In current societies, genetics has an aura of objectivity, of being able to produce "certainties" and "truths" (Nelkin \& Lindee, 1995). Such notions are interesting to explore in order to understand the crime gover- 
nance aspects from a sociological point of view (Wilson-Kovacs, 2014). They reflect, among others, public perceptions of science and technology, crime and justice, as well as the relationship of trust (or lack thereof) between the citizen, the State and various prominent modern institutions. One of the reasons explaining the importance given to genetic information in criminal investigations is the scientific statute of molecular genetics (Lynch, Cole, McNally, \& Jordan, 2008). From the perspective of several professional groups, from forensic scientists to criminal investigators, judges and prosecutors, attorneys and the general public, DNA technologies and forensic genetic databases allegedly generate "more scientific" information, "more capable" to identify offenders in a quick and credible way (Aas, 2006; Lynch, 2003; Lynch et al., 2008; Machado \& Prainsack, 2012). As such, many commentators have emphasized that the presence of genetic technologies such as DNA profiling in policing and as forensic evidence in courts can improve the efficiency of the criminal justice system.

However, critical commentators have also speculated about the discriminatory potential of genetic technologies in the justice system, and the risks associated with their presumed infallibility in the identification of offenders. In this regard, social sciences have been especially critical about the social implications and policies deriving from genetic technologies bearing an exceptional status of complete ontological and mathematical certainty in contemporary societies (Hindmarsh \& Prainsack, 2010; Kruse, 2016; Williams \& Johnson, 2008). This "genetization" of social life (Heath, Rapp, \& Taussig, 2004; Novas \& Rose, 2000; Rabinow, 1996; Rose, 2007; Rose \& Novas, 2005; Rouvroy, 2008; Wehling, 2011; Weiner, Martin, Richards, \& Tutton, 2017) and the subsequent "genetization" of criminal investigations follow the determinations of what Theodore Porter (1995), North American science historian, designated as "mechanical objectivity". Porter proposed this term to refer to the growing authority and symbolical power of "impersonal numbers" and statistics in various social, political and economic spheres, in detriment of human experiences and assessments (considered "subjective").

This book portrays, under a critical sociological perspective, contemporary ways of reformulating the governance of crime through genetics. Such analysis is linked to a reflection of how the control of information flow and the management of inclusion and exclusion circuits is based upon calculations and risk prediction. It is important to note that this book presents itself as a critical reflection regarding the general enthusiasm shown towards the potential that genetics seemingly have to search and 
identify authors of crimes. In other words, beyond evaluating the plausibility of applying genetics to support criminal investigations and the operation of the justice system, the authors of this publication intend to question the social, cultural, political and ethical implications of using genetics in the field of the governance of crime.

Some questions addressed in this book are the following: What are the main trends of governance of crime in contemporary society through the lens of scientific knowledge and genetic technology? What place and role do genetics occupy in the criminal justice system? How can classical and contemporary social theory help to address current challenges posed by the social processes and interactions generated by the uses, meanings and expectations attributed to genetics in the governance of crime? Which methods and research techniques can be used by students and scholars to address some crucial aspects of this particular social reality? Which new challenges emerge from the recent paradigm shift within forensic genetics, moving from the construction of evidence to be presented in court to the production of intelligence to guide the course of a particular criminal investigation?

\section{Book Overview}

The scientific breakthroughs that have made it possible to use DNA as a tool of human identification began in the 1980s of the twentieth century. The first patent that would originate the modern processes of DNA profile extraction was registered by the biologist Jeffrey Glassberg (US) in 1983, and would subsequently be used by the Federal Bureau of Investigation (FBI). In the UK, the biologist Alec Jeffreys from the University of Leicester developed a method to extract DNA profiles in late 1984. The first criminal case solved by this technique was the rape and murder of two teenagers, which took place from 1983 to 1986 in Narborough, Leicestershire (England). This criminal case gained widespread coverage, both because it involved a technological breakthrough and due to the circumstances of the investigation. The criminal investigators asked for blood samples of about 5000 men residing in the geographical area around the crime scene. The goal was to perform DNA analysis, which eventually exonerated a first suspect who had already confessed to the crimes. Afterwards, blood was collected from another man-Colin Pitchforkand it was found that his genetic profile matched the DNA found in the 
crime scene. In other words, this individual was identified as the one responsible for both crimes following an analysis of DNA profiles.

This and other success stories have contributed to disseminate social representations that characterize DNA technologies as "crime fighting heroes", a kind of "truth machines" promising to remove judicial errors from the equation and sentence the authors of crime (Lynch et al., 2008). However, these assumptions forgo the necessarily complex and varied understanding of social reality. The second chapter of this book will present a systematization of the approach taken by sociology and other social sciences that aim to critically discuss the widespread success stories of DNA technologies. These stories have grown to be more common in societies ruled by the mystique associated with genes, reflecting and reproducing social processes involving relationships of power, knowledge, hierarchization and social inequalities.

The consolidation of the role of genetics in social life has also invigorated old discussions about the role played by biological and biosocial approaches aiming to explain and predict violent and criminal behaviour (Duster, 2003). By extension, this type of debate raises issues linked to biological determinism, in a way that might lead to promote renewed insight and initiatives focused on matters of social exclusion, marginalization and stigmatization. As such, there is the need to undertake a historical and sociological overview of the biological explanations for anti-social, violent and criminal behaviour. Therefore, the third chapter of this book aims to provide a detailed description of the seminal work by Lombroso (nineteenth century) and highlights the risks of biological determinism and potential stigmatization raised by this line of research. It then discusses current trends of biologization and genetization of crime, by focusing on the specific studies in the fields of neurobiology and epigenetics.

State governance strategies have been fostered based upon DNA potential for individualization. They are supported by a rhetoric that celebrates the efficiency and infallibility of science and technology. At the same time, they reduce the space allowed for criticism or dissonant voices which do not follow the values and ideologies of the dominant social order. Taking a critical perspective of this scenario, the fourth chapter of this book describes and systematizes the approaches of social sciences to the presence of DNA evidence in court.

A significant number of studies undertaken since the mid-90s of the twentieth century, mainly in the US, have addressed the social implications and the transformations in professional cultures and practices stem- 
ming from the presence of DNA technologies in the criminal justice system. Such contributions highlight the way DNA technologies shape new ways of governance of crime with profound implications thereof in the social structure, citizen rights and democratic dynamics in current societies.

The substantial potential of the DNA profiling methods created and developed in the US and the UK at the tail-end of the 80s to support the identification of authors of crimes led to efforts by law enforcement authorities in the following decade to develop ways to add the genetic profiles of people with criminal records to computerized databases. Therefore, 1995 saw the creation of the first criminal database featuring genetic profiles on a national context: the UK National Criminal Intelligence DNA Database. Other countries have started processes to create their own national genetic databases. Namely, and to cite the largest databases currently existing in Europe, Austria and the Netherlands started theirs in 1997, Germany in 1998 and France in 2001.

A database of DNA profiles is constituted by a structured set of DNA profile files and personal data profiles, which can be accessed according to the predetermined legislation in effect in each country. These databases involve the collection, storage and use of genetic profiles belonging to identified suspects, convicted individuals, victims, voluntaries and other persons of interest to the criminal investigation. Nearly 69 countries are currently using forensic genetic databases, and there are estimates that this type of database is beginning to be implemented in about 34 other countries (Interpol, 2016). The fifth chapter of this book will present the different implications of the creation and development of forensic genetics databases, considering the necessary balance between curtailing civil rights and protecting society's security.

Looking at forensic databases as a particularly ostentatious form of genetic surveillance of criminalized populations, we will discuss them within the scope of a society that is growingly focused on intensifying and accelerating the mass circulation and interlinking of data. In this context, the cultural and socio-economic phenomenon of big data is approached in this chapter as a part of a datafied society (Broeders \& Dijstelbloem, 2016; French \& Smith, 2016; Sadowski, 2019; Smith, 2016; van Dijck, 2014) where bio-surveillance technologies gain prominence. In other words, technologies based on processing information are linked to biological materials originating in the human body (Hindmarsh \& Prainsack, 2010; Kloppenburg \& van der Ploeg, 2018; Skinner, 2018b). 
The forensic genetic databases and the associated DNA technologies are, therefore, continuously being expanded and developed, seeing as one of the facets of this expansion is also its growing interoperability. With the goal of strengthening police cooperation in the European Union, we have seen a rise in the number of international mechanisms for population surveillance and control. The sixth chapter focuses on this theme, particularly the way the opening of the European Union's borders was followed by a proliferation of control mechanisms for transnational criminality. Among them, we outline the Prüm System, which represents a network created between EU Member States to exchange data stored in the national databases of various countries in the Union, with the goal of combating terrorism and cross-border criminality.

The implementation, development and expansion of the Prüm System have led to heated debates on issues of transparency, accountability and data privacy (McCartney, 2014; Prainsack \& Toom, 2010; Toom, 2018; Toom, Granja, \& Ludwig, 2019).

In a context marked by a datafied society, concepts such as ethnicity, race and national identity are recycled by the operators of forensic genetic databases as practical categories. These operational categories are mobilized as organizing principles and consequently sustained by a kind of rationality that assumes these categories as acquired data (Fujimura \& Rajagopalan, 2011). However, several authors (Cole, 2007; Duster, 2006; Risher, 2009) have warned about the fact that new surveillance technologies have, inversely, reinforced the legitimacy of old prejudice and even created new ways to stigmatize and exclude, from the moment the surveillance technologies operate based on principles that separate suspect from non-suspect individuals (Van der Ploeg, 1999).

Following functional imperatives, a set of practices that would otherwise elicit some ethical reservations due to the curtailing of civil rights are applied to criminal investigations. In particular, we outline the following technologies: familial searching, that is, the act of looking up profiles in forensic DNA databases that are genetically close to a known sample that was collected at the crime scene (García, Crespillo, \& Yurrebaso, 2017; Granja \& Machado, 2019; Haimes, 2006; Murphy, 2010) and intelligenceled DNA massive screenings, consisting in collecting a significant number of DNA profiles in a specific area where the suspect is thought to reside (Chapin, 2004; Duster, 2008). In addition, the inference of geographical ancestry, performed upon determination of the statistical distribution of the genetic profiles by zone and the subsequent proximity of the known 
sample to a probable area of origin is used in tandem with the inference of physical features through DNA. The joint use of these two technologies is commonly known as forensic DNA phenotyping (M'charek, 2008; Queirós, 2019; Samuel \& Prainsack, 2018, 2019; Skinner, 2018a; Vailly, 2017; Wienroth, 2018a, 2018b). The seventh chapter of this book will take a look at the use of these emerging DNA technologies and the notable scientific, ethical and legal controversies that have come to the fore.

Finally, the eighth and last chapter of the book will revisit, under a critical perspective, the multiplicity of roles and meanings of forensic genetics in the governance of crime in contemporary societies, while providing clues for future pathways for research in the field of social studies of forensic genetics.

\section{REFERENCES}

Aas, K. F. (2006). "The body does not lie": Identity, risk and trust in technoculture. Crime, Media, Culture, 2(2), 143-158. https://doi.org/10.1177/ 1741659006065401

Broeders, D., \& Dijstelbloem, H. (2016). The datafication of mobility and migration management: The mediating state. In I. Van der Ploeg \& J. Pridmore (Eds.), Digitizing identities: Doing identity in a networked world (pp. 242260). London: Routledge. https://doi.org/10.4324/9781315756400

Chapin, A. B. (2004). Arresting DNA: Privacy expectations of free citizens versus post-convicted persons and the unconstitutionality of DNA dragnets. Minnesota Law Review, 89, 1842-1875. Retrieved from http://heinonlinebackup.com/ hol-cgi-bin/get_pdf.cgi?handle=hein.journals $/$ mnlr89\&section $=58$

Cole, S. (2007). How much justice can technology afford? The impact of DNA technology on equal criminal justice. Science and Public Policy, 34(2), 95-107. https://doi.org/10.3152/030234207X190991

van Dijck, J. (2014). Datafication, dataism and dataveillance: Big Data between scientific paradigm and ideology. Surveillance \& Society, 12(2), 197-208.

Duster, T. (2003). Backdoor to engenics. New York: Routledge.

Duster, T. (2006). The molecular reinscription of race: Unanticipated issues in biotechnology and forensic science. Patterns of Prejudice, 40(4-5), 427-441. https://doi.org/10.1080/00313220601020148

Duster, T. (2008). DNA dragnets and race: Larger social context, history and future. GeneWatch, 2l(3-4), 3-5. Retrieved from http://scholar.google.com/ scholar?hl=en\&btnG=Search\&q=intitle:DNA+Dragnets+and+Race+:+Larger+ Social+Context+,+History+and+Future\# 1 
Feeley, M. M., \& Simon, J. (1992). The new penology: Notes on the emerging strategy of corrections and its implications. Criminology, 30(4), 449-474.

French, M., \& Smith, G. (2016). Surveillance and embodiment: Dispositifs of capture. Body \& Society, 22(2), 1-25. https://doi.org/10.1177/1357034X 16643169

Fujimura, J., \& Rajagopalan, R. (2011). Different differences: The use of "genetic ancestry" versus race in biomedical human genetic research. Social Studies of Science, 41(1), 5-30. https://doi.org/10.1177/0306312710379170

García, Ó., Crespillo, M., \& Yurrebaso, I. (2017). Suspects identification through "familial searching" in DNA databases of criminal interest. Social, ethical and scientific implications. Spanish Journal of Legal Medicine, 43(1), 26-34. https://doi.org/10.1016/j.remle.2017.02.002

Garland, D. (2001). The culture of control: Crime and social order in contemporary society. Chicago: The University of Chicago Press.

Granja, R., \& Machado, H. (2019). Ethical controversies of familial searching: The views of stakeholders in the United Kingdom and in Poland. Science, Technology, \& Human Values, 44(6), 1068-1092. https://doi. org/10.1177/0162243919828219

Haimes, E. (2006). Social and ethical issues in the use of familial searching in forensic investigations: Insights from family and kinship studies. Journal of Law, Medicine \& Ethics, 34(2), 263-276. https://doi.org/10.1111/ j.1748-720X.2006.00032.x

Heath, D., Rapp, R., \& Taussig, K.-S. (2004). Genetic citizenship. In D. Nugent \& J. Vincent (Eds.), A companion to the anthropology of politics (pp. 152-167). Malden, MA: Blackwell.

Hindmarsh, R., \& Prainsack, B. (Eds.). (2010). Genetic suspects: Global governance of forensic DNA profiling and databasing. Cambridge: Cambridge University Press.

Interpol. (2016). Global DNA profiling survey results 2016. Lyon.

Kloppenburg, S., \& van der Ploeg, I. (2018). Securing identities: Biometric technologies and the enactment of human bodily differences. Science as Culture, 1-20. https://doi.org/10.1080/09505431.2018.1519534

Kruse, C. (2016). The social life of forensic evidence. Oakland, CA: University of California Press.

Lynch, M. (2003). God's signature: DNA profiling, the new gold standard in forensic science. Endeavour, 27(2), 93-97.

Lynch, M., Cole, S., McNally, R., \& Jordan, K. (2008). Truth machine: The contentious history of DNA fingerprinting. Chicago: University of Chicago Press.

Lyon, D. (2002). Surveillance as social sorting. Hoboken: Taylor \& Francis Ltd.

M'charek, A. (2008). Silent witness, articulate collective: DNA evidence and the inference of visible traits. Bioethics, 22(9), 519-528. https://doi. org/10.1111/j.1467-8519.2008.00699.x 
Machado, H., \& Prainsack, B. (2012). Tracing technologies: Prisoners' views in the era of CSI. Farnham, UK: Ashgate.

McCartney, C. (2014). Transnational exchange of forensic evidence. In G. Bruinsma \& D. Weisburd (Eds.), Encyclopedia of criminology and criminal justice (pp. 5302-5313). New York: Springer. https://doi.org/10.1007/ 978-1-4614-5690-2

Murphy, E. (2010). Relative doubt: Familial searches of DNA databases. Michigan Law Review, 109(3), 291-348. https://doi.org/10.2307/25759291

Nelkin, D., \& Lindee, M. S. (1995). The DNA mystique: The gene as a cultural icon. New York: W H. Freeman.

Novas, C., \& Rose, N. (2000). Genetic risk and the birth of the somatic individual. Economy and Society, 29(4), 485-513. https://doi.org/10.1080/ 03085140050174750

Porter, T. M. (1995). Trust in numbers: The pursuit of objectivity in science and public life. Princeton, NJ: Princeton University Press.

Prainsack, B., \& Toom, V. (2010). The Prüm regime. Situated dis/empowerment in transnational DNA profile exchange. British Journal of Criminology, 50(6), 1117-1135. https://doi.org/10.1093/bjc/azq055

Queirós, F. (2019). The visibilities and invisibilities of race entangled with forensic DNA phenotyping technology. Journal of Forensic and Legal Medicine, 68, 1-7. https://doi.org/10.1016/J.JFLM.2019.08.002

Rabinow, P. (1996). Artificiality and enlightenment: From sociobiology to biosociality. In Essays on the anthropology of reason (pp. 91-111). Princeton, NJ: Princeton University Press.

Risher, M. T. (2009). Racial disparities in databanking of DNA profiles. GeneWatch, 22(3-4), 22-24. Retrieved from http://www.councilforresponsiblegenetics. org/pageDocuments/BBIQ0EKC20.pdf

Rose, N. (2007). The politics of life itself: Biomedicine, power, and subjectivity in the twenty-first century. Princeton: Princeton University Press.

Rose, N., \& Novas, C. (2005). Biological citizenship. In S. J. Collier \& A. Ong (Eds.), Global assemblages: Technology, politics, and ethics as anthropological problems (pp. 439-463). Malden, MA: Blackwell Publishers.

Rouvroy, A. (2008). Human genes and neoliberal governance: A Foucauldian critique. New York: Routledge-Cavendish.

Sadowski, J. (2019). When data is capital: Datafication, accumulation, and extraction. Big Data \& Society, 6(1), 1-12. https://doi.org/10.1177/ 2053951718820549

Samuel, G., \& Prainsack, B. (2018). Forensic DNA phenotyping in Europe: views "on the ground" from those who have a professional stake in the technology. New Genetics and Society, 1-23. https://doi.org/10.1080/14636778. 2018.1549984 
Samuel, G., \& Prainsack, B. (2019). Civil society stakeholder views on forensic DNA phenotyping: Balancing risks and benefits. Forensic Science International: Genetics, 43, 102157. https://doi.org/10.1016/j.fsigen.2019.102157

Skinner, D. (2018a). Forensic genetics and the prediction of race: What is the problem? BioSocieties, 1-21. https://doi.org/10.1057/s41292-018-0141-0

Skinner, D. (2018b). Race, racism and identification in the era of technosecurity. Science as Culture, 1-23. https://doi.org/10.1080/09505431.2018.1523887

Smith, G. (2016). Surveillance, data and embodiment: On the work of being watched. Body \& Society, 1-32. https://doi.org/10.1177/1357034X 15623622

Toom, V. (2018). Cross-border exchange and comparison of forensic DNA data in the context of the Prïm Decision. Civil liberties, justice and home affairs. Retrieved from http://www.europarl.europa.eu/thinktank/en/document. html?reference=IPOL_STU(2018)604971

Toom, V., Granja, R., \& Ludwig, A. (2019). The Prüm Decisions as an aspirational regime: Reviewing a decade of cross-border exchange and comparison of forensic DNA data. Forensic Science International: Genetics, 41, 50-57. https:// doi.org/10.1016/j.fsigen.2019.03.023

Vailly, J. (2017). The politics of suspects' geo-genetic origin in France: The conditions, expression, and effects of problematisation. BioSocieties, 12(1), 66-88. https://doi.org/10.1057/s41292-016-0028-x

Van der Ploeg, I. (1999). Written on the body: Biometrics and identity. Computers and Society, March, 37-44.

Wehling, P. (2011). Biology, citizenship and the government of biomedicine: exploring the concept of biological citizenship. In U. Bröckling, S. Krasmann, \& T. Lemke (Eds.), Governmentality. Current issues and future challenges (pp. 225-246). New York: Routledge.

Weiner, K., Martin, P., Richards, M., \& Tutton, R. (2017). Have we seen the geneticisation of society? Expectations and evidence. Sociology of Health and Illness, 39(7), 989-1004. https://doi.org/10.1111/1467-9566.12551

Wienroth, M. (2018a). Governing anticipatory technology practices. Forensic DNA phenotyping and the forensic genetics community in Europe. New Genetics and Society, 1-16. https://doi.org/10.1080/14636778.2018. 1469975

Wienroth, M. (2018b). Socio-technical disagreements as ethical fora: Parabon NanoLab's forensic DNA Snapshot ${ }^{\mathrm{TM}}$ service at the intersection of discourses around robust science, technology validation, and commerce. BioSocieties, 1-18. https://doi.org/10.1057/s41292-018-0138-8

Williams, R., \& Johnson, P. (2008). Genetic policing: The use of DNA in criminal investigations. Cullompton: Willan Publishing.

Wilson-Kovacs, D. (2014). "Backroom Boys": Occupational dynamics in crime scene examination. Sociology, 48(4), 763-779. https://doi.org/10.1177/ 0038038513503741 
Open Access This chapter is licensed under the terms of the Creative Commons Attribution 4.0 International License (http://creativecommons.org/licenses/ by $/ 4.0 /$ ), which permits use, sharing, adaptation, distribution and reproduction in any medium or format, as long as you give appropriate credit to the original author(s) and the source, provide a link to the Creative Commons licence and indicate if changes were made.

The images or other third party material in this chapter are included in the chapter's Creative Commons licence, unless indicated otherwise in a credit line to the material. If material is not included in the chapter's Creative Commons licence and your intended use is not permitted by statutory regulation or exceeds the permitted use, you will need to obtain permission directly from the copyright holder.

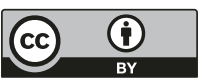




\title{
The Sociological Gaze
}

\begin{abstract}
This chapter provides an explanation and context for situating the particular approach of sociology to the social phenomenon of the uses of forensic genetics in criminal justice systems. The aim is to describe, in an accessible manner, why the governance of crime using science and technology is a fertile domain for sociological enquiry and identify its distinctive features. This chapter provides a comprehensive overview of the main lines of enquiry and concepts of sociological paradigms, namely by focusing on the continuum, tensions and translations between distinctive levels of analysis: micro-macro and objective-subjective. The presentation of the lines of social thought and concepts is accompanied by a brief reference to practical cases of empirical research related to the use of forensic genetics in the criminal justice system. The chapter will enable the reader to acquire theoretical and analytical skills which may be applied in academic research into the various topics and themes addressed in the book's different chapters.
\end{abstract}

Keywords Sociological paradigms $\bullet$ Micro and macro $\bullet$ Objective and subjective $\bullet$ Consensus and conflict 


\section{Paradigms of Sociological Thought}

Sociology is a scientific discipline that presents different theoreticalanalytical lines of thought to question society. Therefore, the sociological gaze upon forensic genetics and its role in the governance of crime is liable to adopt different ways to question our social reality. The main goal of this chapter is to systematize the main guiding lines of sociological theories and indicate how they may be applied to the study and analysis of forensic genetics in criminal justice systems.

According to George Ritzer's point of view (1992), it is possible to distinguish three main paradigms in sociological thought: the paradigms of the social-facts, social-definition and social-behaviour. The last of these paradigms is linked to an analysis model close to experimental psychology, based on social behaviourism models. Considering that such paradigm has no representation in sociological approaches to forensic genetics, it will not be addressed in this work.

The social-facts paradigm focuses on what Émile Durkheim (1895 [1964], 1897 [1951]) termed as social facts: values, cultural norms and social structures that transcend the individual and can exercise social control. Theorists who adhere to this paradigm study social structures and institutions on a large scale. In terms of favoured research methods, they tend to adopt structured interviews and questionnaires, as well as historicalcomparative methods. The social-facts paradigm encompasses a number of theoretical perspectives. Different or even opposing sociological theories can be framed by this paradigm: both structural functionalism (usually associated with the work of Talcott Parsons and his followers) and the so-called conflict theories (who were founded by Karl Marx). According to Ritzer, "Structural-functional theorists tend to see social facts as neatly interrelated and order as maintained by general consensus. Conflict Theorists tend to emphasize disorder among social facts as well as the notion that order is maintained by coercive forces in society" (Ritzer, 1992, p. 641).

Concrete examples are presented for the application of this paradigm when analysing the role of forensic genetics in the governance of crime: a functional perspective will tend to focus on the modes whereby sociotechnical systems can foster cooperation, solidarity and harmony between social groups, as well on the forms whereby controversies can be solved and stabilized. Regarding the social expectations about the role of forensic genetics in the governance of crime, this perspective will be interested in studying the way police cooperation among countries can contribute to make society safer. On the contrary, the standpoint of conflict theories will 
argue that technology should be regarded as the outcome of conflicting ideas and interests, being liable to reflect social relationships marked by domination by one of the parties and mirror social and economic inequalities (Hard, 1993). This perspective will look at international security policies as a mechanism for social control that is able to boost geopolitical inequalities and reflects the interests of the most powerful social groups.

The social-definition paradigm follows an approach based on understanding and interpreting social action, and is inspired by the works of Max Weber (1949). This paradigm is focused on analysing the way that the social actors define their social relationships and their connected social contexts, as well as the effects of those definitions on the development of actions and interactions. In terms of methods, this paradigm privileges unstructured or semi-structured interviews, as well as the direct observation of social interactions. Several sociological theories can be included in this paradigm: action theory, symbolic interactionism, phenomenology, ethnomethodology and existentialism.

Many authors have defended that sociology must integrate the various paradigms and not establish hermetic, rigorous divisions between social structures and human agency. A multi-paradigm perspective will assume that the social world is constituted by multiple social phenomena, which require different levels of analysis but are mutually dependent. However, it is useful taking into consideration various paradigms and conceptual schemes that help identify and understand the complexities of the social world (Table 2.1).

Table 2.1 Paradigms of sociological thought

\begin{tabular}{lll}
\hline & \multicolumn{2}{l}{ Paradigm } \\
\cline { 2 - 3 } & Social facts & Social definition \\
\hline Main authors & Émile Durkheim & Max Weber \\
Basic concepts & Social structure & Human agency \\
Object of the & Values, cultural norms and & Social relationships and interactions \\
study & Social structures & \\
Methods & Structured interviews & Unstructured interviews \\
& Questionnaires & Semi-structured interviews \\
Sociological & Historical-comparative methods & Direct observation of social interaction \\
theories & Structural functionalism & Action theory \\
& Conflict theories & Symbolic interactionism Phenomenology \\
& & Ethnomethodology \\
& & Existentialism
\end{tabular}




\section{Social Studies of Forensic Genetics}

\section{Inauguration of the Field of Study}

Several studies undertaken in the field of social studies for forensic genetics come close to the Social-Definition Paradigm, inasmuch as a considerable part of the research performed is interested in perceptions, expectations and representations that the social actors confer to forensic genetics technologies. A paradigmatic example of this type of research based on understanding and interpreting social situations can be seen in the works of sociologist Michael Lynch, who was fundamental in the inauguration and development of the field of social studies in forensic genetics. This author made use of ethnomethodology, a method of sociological analysis that examines how individuals use everyday conversation to construct a common-sense view of the world (Lynch, 1993).

In this regard, we should highlight the study developed by Michael Lynch and a team of sociologists and other social scientists, with the support of the National Science Foundation and the Department of Science and Technology at Cornell University. The authors developed a multilocation study that involved the UK and the US while covering a period of 15 years. This period ranges from the moment DNA technologies began to be actively discussed in courts and scientific journals (the late 80s) until the time such technologies were established as the "gold standard" (Lynch, Cole, McNally, \& Jordan, 2008, p. xiii). This far-reaching work made use of document analysis, conduction of interviews with scientists and professionals working for the criminal justice system and observation of scientific laboratories and criminal trials.

With the goal of studying the intersection between science and law, the credibility of expert testimony, and historical comparisons between DNA evidence and other criminal identification tools, this team developed work that, although focusing on a "micro" dimension of reality-the perceptions attributed to DNA technology-sought to conjugate it with a "macro" analysis that made it possible to frame and give historic and social meaning to the materials being collected and analysed. The study's results showed very clearly this duality. In order to explain how forensic DNA evidence increasingly gained an exceptional factual status in courts of law, Lynch and his colleagues showed that the objectivity and infallibility attributed to DNA evidence is the result of practical, day-to-day actions, a phenomenon named "administrative objectivity". This administrative 
objectivity of DNA evidence rests upon observable and reportable bureaucratic rules, records, recording devices, protocols and architectural arrangements (Lynch, 2013; Lynch et al., 2008). Beyond those points, the team also showed how the controversies around DNA profiling technologies reflect different professional interests and mirror socio-political and structural aspects linked to the criminal justice system of the US (Daemmrich, 1998; Jasanoff, 1995)

Despite its ethnographic character, this study is a paradigmatic example of the potential of integrating various sociological paradigms. This collective work originated the pivotal publications "Truth machine: The contentious history of DNA fingerprinting" (Lynch et al., 2008). Other results of this study were published in 1998, on a special issue of the journal Social Studies of Science, which continues to be one of the most prestigious publications in the field of social sciences focusing on science and technology. This special issue analysed the presence of forensic genetics in courts, and among other aspects tried to understand the implications of two different ways of acting and thinking coming together: the world of science and the world of law.

One of the study cases undertaken by Michael Lynch's team, addressed in this special issue of the journal Social Studies of Science, was the criminal trial of O.J. Simpson, an American actor and former football player. In 1994, O.J. Simpson was accused of murdering his ex-wife Nicole Brown and her friend Ronald Goldman. DNA evidence was presented during the criminal trial: both the defence and the prosecution called specialists to court who had published about DNA profiling techniques, which led to a heated debate on the controversies brought to the fore by this scientific technique. The case opened a complex field of questioning with several sociological ramifications, namely in terms of issues linked to the interpretation of DNA evidence, public versus expert understanding of science, adequate and inadequate practices, as well as the relationship between the credibility of the DNA evidence and the larger infrastructure that supports the activities of both police forces and scientists (Lynch \& Jasanoff, 1998).

\section{Relationship Between the Macro and Micro Level}

Most classic sociological theories study the new social structures that have emerged during modernity, which made it possible for scientific knowledge to penetrate and transform social relationships. Several of these structures frame scientific development and have allowed its expansion 
and legitimacy, supporting the social, historic and economic process that transformed science into one of the most important modern institutions. For example, classical authors analysed bureaucracy (Max Weber), capitalism (Karl Marx) or organic solidarity (Émile Durkheim). Various authors have debated the existing tension between macro and micro levels, trying to understand the connections between both levels of analysis, while giving birth to a fruitful and extended debate about the tension and ways to articulate human agency and social structure (Bourdieu, 1977; Giddens, 1979, 1984).

Such an analysis about the macro and micro levels is also fundamental to understand how knowledge prerogatives regarding DNA technologies translate, on the one hand, the meaning, intention and interpretation given by one or more social actors and, on the other hand, the broader social structures and contexts. A close analysis of the creation and development of those interactions and social structures is helpful to understand how a single act to vindicate the plausibility of a technology that extracts DNA profiles from biological samples ("discovered" by one individual or particular groups, in a specific point in time and space) has become part of a broader social structure. How did that knowledge-"scientific breakthrough"- stabilize? Which new relationships and social structures were formed and consolidated by articulating macro and micro levels?

In the late eighties and early nineties, when DNA profiling technologies began to be used as auxiliary tools in criminal identification, there were not any protocols nor rules regarding the interpretation of the information obtained from genetic profiles. Likewise, there was not a consensus in the scientific community about how to perform DNA analyses and interpret the results (Aronson, 2008; Derksen, 2010; Lynch, 1998). Nowadays, things are different: there are protocols, quality patterns for laboratories and legal frameworks. That is to say, a broad and stable network of social structures was created to frame and sustain the production and dissemination of knowledge about forensic genetics and its generalized acceptance in the criminal justice system (Hindmarsh \& Prainsack, 2010; Lynch et al., 2008; Williams \& Johnson, 2008). The scientific knowledge that led to the discovery of DNA technologies was, therefore, expanded from its local production context and integrated into the social order of various institutions, consequently stepping up from the microinteraction level to the social structure's macro level (Daemmrich, 1998; Derksen, 2003). In other words, we could say that the consensus around 
DNA technologies represents the outcomes of successful knowledgemaking activities (Derksen, 2010; Knorr-Cetina, 1999; Shapin, 1986).

When analysing the relationships between the micro and macro levels of social reality, we will consider the research undertaken by the sociologist Linda Derksen, who studied the development of DNA profiling technologies and their application in the justice system of the US (Derksen, $2000,2003,2010)$. The author resorted to two theoretical sociology guiding lines: sociology of scientific knowledge (SSK) and the sociological theories which articulate macro and micro levels. Her approach uses examples from the history of DNA profiling to show specific, particular moments where the micro (for instance, consensus between two people about the validity of a DNA profile interpretation method) and macro (e.g., creating legislation for databases with thousands of genetic profiles) levels were translated into one another. Therefore, the author studied examples from the history of DNA profiling which show specific moments of translation where new knowledge is produced at micro level and is then taken up-entrenched-into new social structures at macro level (see also Aronson, 2008). In concrete terms, Linda Derksen argues that the stabilization and standardization process of scientific knowledge generated around DNA profiling technologies led to the creation of new and diverse social structures. These social structures are what Anthony Giddens defines as rules and regulations and institutionalized patterns of behaviour (Giddens, 1984).

By applying the notion of social structure to DNA profiling technologies, we may refer to the stabilization of practices and protocols, the formation of expert communities and their professional associations, the creation of standards for laboratory practices and quality monitoring, as well as to the construction of databases, political projects and legislation. It should be noted that one social structure encapsulates formal and informal dimensions of social relations, knowledge and tacit rules, as well as legislation and regulations, without forgetting material resources and advisory and governing bodies. At a more macro level, we can even mention a type of society and culture that has made it possible to develop and expand DNA profiling databases and put them in the service of a criminal justice system: in this case, we are discussing a capitalist society and a Western culture.

For example, a concrete example of the creation of new and diverse social structures in forensic genetics is linked to the case of England and Wales, who created, in 1995, the first forensic DNA database: the National 
DNA Database (NDNAD). Because of its significant expansion, from an early stage, NDNAD began to deal with the societal effects triggered by various ethical controversies concerning the massive social implications linked to its size and scope (Human Genetics Commission, 2009; Nuffield Council on Bioethics, 2007; Skinner, 2013). These experiences have stimulated the development of stricter regulation to protect citizens' rights and, by extension, have also motivated the creation of particular social structures. Nowadays, the system of oversight of the NDNAD is formed by a partnership of boards and appointed experts, including (but not restricted to): the National DNA Database Strategy Board that provides governance and oversight over the operation of the National DNA Database and the National Fingerprint Database; The UK National DNA Database Ethics Group that provides independent advice on ethical issues; The Biometrics Commissioner whose role is to keep under review the retention and use by the police of DNA samples, DNA profiles and fingerprints; and The Forensic Science Regulator that ensures that the provision of forensic science services across the criminal justice system is subject to appropriate scientific quality standards.

\section{Continuum Between Subjective and Objective}

Another level of sociological analysis is linked to the relationship between "subjective" and "objective". While the subjective field is in the sphere of ideas, the objective one refers to real, material events (Ritzer, 1992, p. 643). Every society has an objective dimension-for example, laws and bureaucracy_and a subjective dimension-norms and values.

The continuum between subjective and objective is important to understand another crucial element of DNA technologies: the analysis of a genetic sample and the interpretation of the genetic profile extracted from that sample involve an act of translation and materialization into quantifiable values. The act of deciding if a specific genetic profile matches another genetic profile involves an assessment and also entails communicating and revealing publicly to other laboratories a quantity called the standard error of measurement. The existence of protocols for the interpretation of genetic analyses and the quantification of the standard error of measurement turn subjective assessments and evaluative statements invisible, thereby producing a kind of knowledge considered as "objective" (Derksen, 2000). As the science historian Theodor Porter indicates, quantification is one of the most important tasks in scientific 
practice because it transforms a knowledge claim from one which originates in a specific place and time to one which seems as if it could come from anywhere (Porter, 1995).

Quantification makes it possible to translate results into numbers, "erasing" the makes of human work (subjective) from the creation of scientific knowledge (which is supposed to be objective). In Western cultures, quantification is one of the most important processes to create what we call objective knowledge and "facts". In the words of Linda Derksen, "successful quantification hides the representing subject, it hides subjective judgments and it renders judgment invisible" (Derksen, 2010, p. 223). This creation process of "objective" knowledge through protocols, standards and turning certain classifications invisible (Bowker \& Star, 1999) made it possible for DNA profiling technologies to be seen as increasingly credible and reliable.

Laboratory studies, ${ }^{1}$ which were quite popular at the start of the $90 \mathrm{~s}$, showed, through ethnographic observation, how scientists generate among themselves interactive processes that make it possible to reach a consensus, in order to agree upon what a good match is or is not. In other words, accurate measurements are contingent, local achievements (Derksen, 2000; Kruse, 2016; Lynch et al., 2008). Some authors have noted the existence of cooperation activities, aiming to reach consensus, so a standard can be expanded and used by heterogeneous communities, as well as used in different activities and places (Bowker \& Star, 1999)—an approach that is close to the functionalist perspective.

On the contrary, other authors have emphasized activities of differentiation and conflict, which leads to specific professional groups being able to impose their interests while driving away those of others. One example of this approach, as connected to the abovementioned conflicts theories, is the study undertaken by Jay Aronson on the role of the FBI in standardizing the techniques for forensic DNA profiling. According to the author, this standardization was the result of FBI practices with the goal of becoming the dominant agents in the market of supply of forensic genetics analysis services. To be successful, the FBI agents created a technological

\footnotetext{
${ }^{1}$ Laboratory studies represent the study of science and technology through direct observation and discourse analysis at the root where knowledge is produced and constituted as such. This approach is very emblematic of the way the micro and macro dimensions intersect. On the one hand, laboratory social studies are focused on practices and interactions in a specific location (the scientific laboratory), while on the other hand, they highlight the construction and consolidation of power relations in modern societies (Knorr-Cetina, 1995).
} 
infrastructure and a laboratory network that imposed their approach to the activities already being developed by private companies. At the same time, the FBI recruited prestigious forensic scientists to validate and lend credibility to the products and methods being developed by them (Aronson, 2008). This kind of approach allows us to understand how the stabilization of networks and structures for some actors may lead to the exclusion of others-a kind of perspective that emphasizes power inequalities within forensic genetics (Quinlan, 2014).

After "stabilizing" the credibility of DNA profiling technologies, it was possible to store the DNA profiles in vast computer databases and disseminate them among the different social actors in the justice system, locally, nationally and internationally. Nowadays, DNA profiles can be shared and compared between different laboratories, provided that they use the same computer system and have adopted the same protocols (Aronson, 2007, 2008; Machado \& Granja, 2018; Santos, 2017).

The possibility of DNA profiles being "portable" was made attainable due to the creation of protocols and standards. Subsequently, this led to the expansion and consolidation of the use of forensic genetics in the criminal justice system, including a reinforcement of the cooperation mechanisms between police forces of different countries-a theme which will be addressed on Chap. 7 of this book. When knowledge is transformed into a quantitative format, it is easier for that knowledge to "travel" outside the place where it was produced and being appropriated or used by other social actors (Machado \& Granja, 2018)-in other words, through quantification, forensic geneticists can assume that the knowledge produced in a specific location follows "universal" guidelines that can be replicated by different people in different locations and reach the same results, thereby obtaining a kind of "local universality" (Timmermans \& Berg, 1997).

\section{Consolidation of the Social Studies in Forensic Genetics}

The continuum between subjective and objective is very complex and intersects with macro and micro levels of social reality. The various works undertaken within the social studies of forensic genetics, consolidating it as an autonomous field of study, have shown exactly that relationship, which is also perceived and captured through different methodological strategies. In this last section, we will do a brief review of the empirical studies connected to the use of forensic genetics in the criminal justice system. 
Focusing on the specific case of England and Wales, Robin Williams and Paul Johnson (Williams \& Johnson, 2004, 2008) explored the operational, legal and political aspects that have been brought to the fore while establishing and expanding the use of DNA technologies and the NDNAD. Taking into consideration the way different knowledges, practices and routines jointly constituted the NDNAD, the authors have analysed the perspectives of different specialist areas. Coupled with documentary analysis, they conducted 60 semi-structured interviews featuring a range of individuals from organizations directly involved in either making use of or commenting upon the use of DNA profiling in the criminal justice system-the police, forensic scientists, crime scene examiners, legal professionals, legislators and those concerned with human rights issues.

The analysis undertaken by the authors shows how different representations of the potential and actual application of DNA are employed to support alternative ethical assertions about the forensic uses of DNA technologies and DNA databases. The authors differentiate three representations about the perceived "essence" of DNA and its applications in terms of criminal investigation. Firstly, "genetic exceptionalism" which stresses the unique character of genetic material, a perspective generally supported by members of ethics committees and human rights groups. Secondly, "genomic minimalism" which emphasizes the mundane character of forensic uses of non-coding sequences of DNA, more frequently adopted by civil servants working in the criminal justice system. Lastly, "biometric pragmatism" which distinguishes between different sources of DNA material and what may legitimately be done with DNA obtained from these sources. This position is usually mobilized by criminal investigators and prosecutors and by some academic forensic experts (Williams \& Johnson, 2004 , p. 211). Based on their extensive work, the authors, therefore, articulated the perceptions, intentions and interpretations conferred by social actors to DNA to the broader social structures and contexts, namely their professional occupation and respective epistemic cultures (KnorrCetina, 1999).

Another example of the articulation between the macro and micro levels is the study by the sociologist Christopher Lawless (2011). In the aftermath of the closure of the Forensic Science Service (FSS), the leading provider of scientific support to police investigations in the UK, Lawless explored the impact of neoliberal policies in the evolution of the relationship between science and the criminal justice system. The study was based 
on documentary analysis, semi-structured interviews and a focus group with professionals from a commercial forensic science provider. Based on a micro-level analysis, Lawless explored the ways through which neoliberalism-by privatizing services — reformulated the epistemic possibilities for scientists and police professionals. He also showed how that reformulation coexisted with situated practices of resistance to attempts of moulding science into commercial types of knowledge in service of law enforcement. Therefore, Lawless work shows how large-scale phenomena, like the capitalist system and neoliberal policies, directly intertwine with interactions on a micro scale.

Continuing to dwell on the studies that have sought to understand the different perspectives by professionals working on forensic genetics, some authors have also used ethnography to capture and analyse the way some professionals act and assign meaning to their practices. In this regard, we highlight the work of the anthropologist Corinna Kruse, who accompanied the daily procedures of the Swedish National Laboratory of Forensic Science, observing day-to-day operations of a public prosecutor office, a criminal investigation division and a crime scene division, as well as observing trials. This way, Kruse was able to analyse the various instances that constitute DNA's chain of custody. Based upon a research performed on a micro level, that paid attention to the practices and perceptions of social actors, the author showed how the social life of forensic evidence takes into account how knowledge is produced by and transported across a cooperation of an array of epistemic cultures (Kruse, 2016, p. 148).

Generally speaking, the studies referred so far highlight how researchers have "followed", according to the Actor-Network Theory (Latour, 2005 ) traditions, how social actors with various levels of authority, credibility and power act and leave visible traces of their actions, such as protocols, reports, forensic samples and forensic technologies. However, there are other marginal actors, "the one who both belongs and does not belong" (Quinlan, 2014) which also take part in the use of forensic genetics in the governance of crime. One example of these actors are, for instance, the prisoners whose biological samples are collected. On this level, we should refer to the comparative study between Austria and Portugal developed by Helena Machado and Barbara Prainsack. Based on interviews with prisoners, the authors sought to understand the point of view of this group about criminal investigation practices based on DNA technologies. This study brought to light the ambivalent perspectives that prisoners have in relation to DNA technologies. On the one hand, they 
find it an important tool to identify and convict offenders or to acquit and exonerate suspects. On the other hand, they show doubts and uncertainty about the potential abuses they may fall victim to, and about the supposed deterrent effect of DNA technologies in crime prevention (Machado \& Prainsack, 2012).

Continuing in the field of public perception, other authors have also expanded the literature on the social studies of forensic genetics, by conducting studies focused on public perceptions about DNA databases, whether through qualitative methodologies (Anderson, Stackhouse, Shaw, \& Iredale, 2010; Machado \& Prainsack, 2012; Stackhouse, Anderson, Shaw, \& Iredale, 2010; Wilson-Kovacs, Wyatt, \& Hauskeller, 2012) or quantitative ones (an extensive review of the existing studies can be found at Machado \& Silva, 2019). In this regard, we underscore the work of the sociologist Dana Wilson-Kovacs and colleagues (Wilson-Kovacs et al., 2012). By analysing the results of "The Mass Observation Project" which, since 1981, has collected and analysed detailed answers to questions about specific themes in order to gather information about the lives of normal people, this study shows how DNA profiling is seen by the participants as one of the less problematic applications of genetics.

As a whole, these studies reveal how social representations that the social actors may harbour towards forensic genetics (subjective dimension) may vary according to objective dimensions, namely the socio-economic condition, profession, gender, race or ethnicity. For example, the study by Machado and Prainsack (2012) notes how prisoners consider that having their genetic profile on a forensic DNA database managed by the police may reinforce the stigmatization towards individuals who have committed crimes (Machado \& Prainsack, 2012). Other studies have also revealed that individuals from disadvantaged social groups and racial and ethnic minorities present a high degree of mistrust about the use of genetic evidence in the criminal justice system (Curtis, 2009; Duster, 2006; Machado \& Silva, 2019).

\section{CONCluding Remarks}

A sociological approach to the use of forensic genetics in the governance of crime makes it necessary to consider the multiple social actors who interact among themselves, as well as the organizational context where they develop their activities. Developing a sociological study about forensic genetics in the criminal justice system also entails considering macro 
and micro, objective and subjective dimensions that frame and provide context to the interactions and representations of individuals and groups.

Let us begin by considering in detail the multiple social actors involved in the social processes linked to the use of forensic genetics in the criminal justice system. In terms of forensic genetics, we have a significantly heterogeneous community: from the laboratory technicians who receive the biological samples collected at the crime scene and dedicate themselves to analysing the materials to scientists who undertake research in the field of genetics, focusing their actions on innovations within the scope of genetic analysis techniques, without dealing directly with real cases. There are also those scientists who are directly involved with criminal cases, while not necessarily developing research in the field of forensic genetics: they generally have roles such as directors of forensic genetics laboratories, being responsible for the scientific validity of the analysis methods applied (Cole, 2013). Lastly, in several countries, the criminal investigation police forces integrate groups of forensic experts - or police officers with specific training-who visit the crime scenes to select and collect the traces which will subsequently be forwarded for laboratory analysis (Costa, 2017; Kruse, 2016; Santos, 2014). In terms of the criminal justice system, there is an even greater differentiation and diversity of social actors involved, who have diversified types of expert knowledge and professional cultures. They act in different areas: from police forces to court professionals, and the latter group includes judges, prosecutors, attorneys and juries.

The use of forensic genetics in the governance of crime also involves other social actors, whose scope of action has diverse social, political and cultural implications: for instance, the companies which supply equipment, instruments and other materials to laboratories, without forgetting that some of them provide forensic genetics analysis for courts of law (Lawless, 2011; Wienroth, 2018). Another type of social actors are the groups who deal with ethical and legal issues linked to the use of forensic genetics for criminal identification, namely through their role as entities who supervise and monitor the activities of databases which contain thousands of genetic profiles of citizens (Nuffield Council on Bioethics, 2007). Finally, there are also professional organizations in the field of forensic genetics, whose actions have international implications in terms of standardization and harmonization of procedures (e.g., in laboratories, law-enforcement or judicially): the politicians who decide the legal and regulatory framework which governs the application of genetic information in criminal identification; the non-governmental organizations who 
function as critical, vigilant voices regarding the risks of curtailing human rights as a result of the massive expansion of forensic DNA databases; people whose genetic profile is included in such databases (Machado \& Prainsack, 2012), as well as other citizens (Anderson et al., 2010; Stackhouse et al., 2010; Wilson-Kovacs et al., 2012).

Lastly, there is another group that is also part of this diverse set of social actors involved in the social processes linked to the application of forensic genetics in the criminal justice system, a group which is often disregarded by social studies of forensic genetics: the survivors and victims of crime. According to Andrea Quinlan (2014), this group of social actors, who she names marginal actors, "sits simultaneously inside and outside of the legal system's institutional network [...] 'inside' in the sense that their body serves as the" crime scene "from which DNA evidence is gathered [...] 'outside' as they are excluded from many of the practices within the legal system" (Quinlan, 2014). Paying attention to this set of actors would make it possible to create a "network from below" following the tradition of the Actor-Network Theory (Latour, 2005).

The heterogeneous nature of the social actors who are potentially involved in the social phenomenon of application of genetic technologies to the criminal justice system corresponds to different kinds of actions, knowledge, experiences and perspectives on society. Therefore, various sociologically pertinent issues may serve as the basis for studies in the field. The different chapters of this book have the goal of showing the various themes and issues that can be studied through a sociological point of view.

\section{REFERENCES}

Anderson, C., Stackhouse, R., Shaw, A., \& Iredale, R. (2010). The national DNA database on trial: Engaging young people in South Wales with genetics. Public Understanding of Science, 20(2), 146-162. https://doi.org/10.1177/ 0963662510375793

Aronson, J. (2007). Genetic witness: Science, law, and controversy in the making of DNA profiling. Piscataway, NJ: Rutgers University Press.

Aronson, J. (2008). Creating the network and the actors: The FBI's role in the standardization of forensic DNA profiling. BioSocieties, 3(2), 195-215. https:// doi.org/10.1017/S174585520800611X

Bourdieu, P. (1977). Outline a theory of practice. Cambridge: Cambridge University Press. 
Bowker, G., \& Star, S. L. (1999). Sorting things out: Classification and its consequences. Cambridge, MA and London: The MIT Press. https://doi. org/10.1109/MAHC.2000.841148

Cole, S. (2013). Forensic culture as epistemic culture: The sociology of forensic science. Studies in History and Philosophy of Biological and Biomedical Sciences, 44(1), 36-46. https://doi.org/10.1016/j.shpsc.2012.09.003

Costa, S. (2017). Visibilities, invisibilities and twilight zones at the crime scene in Portugal. New Genetics and Society, 36(4), 375-399. https://doi.org/10.108 0/14636778.2017.1394835

Curtis, C. (2009). Public perceptions and expectations of the forensic use of DNA: Results of a preliminary study. Bulletin of Science, Technology \& Society, 29(4), 313-324. https://doi.org/10.1177/0270467609336306

Daemmrich, A. (1998). The evidence does not speak for itself: Expert witnesses and the organization of DNA-typing companies. Social Studies of Science, 28(56), 741-772.

Derksen, L. (2000). Towards a sociology of measurement. Social Studies of Science, 30(6), 803-845. https://doi.org/10.1177/030631200030006001

Derksen, L. (2003). Agency and structure in the history of DNA profiling: The stabilization and standardization of a new technology. San Diego: University of California. Retrieved from https://www.academia.edu/1407355/Agency_ and_structure_in_the_history_of_DNA_profiling_The_stabilization_and_standardization_of_a_new_technology

Derksen, L. (2010). Micro/macro translations: The production of new social structures in the case of DNA profiling. Sociological Inquiry, 80(2), 214-240. https://doi.org/10.1111/j.1475-682X.2010.00328.x

Durkheim, É. (1895). The rules of sociological method. New York: Free Press.

Durkheim, É. (1897). Suicide. New York: Free Press.

Duster, T. (2006). Explaining differential trust of DNA forensic technology: Grounded assessment or inexplicable paranoia? Journal of Law, Medicine is Ethics, 34(2), 293-300.

Giddens, A. (1979). Central problems in social theory: Action, structure and contradiction in social analysis. Berkeley and Los Angeles: University of California Press.

Giddens, A. (1984). The constitution of society. Berkeley and Los Angeles: University of California Press.

Hard, M. (1993). Beyond harmony and consensus: A social conflict approach to technology. Science Technology Human Values, 18(4), 408-432. https://doi. org/10.1177/016224399301800402

Hindmarsh, R., \& Prainsack, B. (Eds.). (2010). Genetic suspects: Global governance of forensic DNA profiling and databasing. Cambridge: Cambridge University Press.

Human Genetics Commission. (2009). Nothing to hide, nothing to fear? Balancing individual rights and the public interest in the governance and use of the National 
DNA Database https://www.statewatch.org/news/2009/nov/uk-dnahuman-genetics-commission.pdf.

Jasanoff, S. (1995). Science at the bar. Law, science, and technology in America. Cambridge, MA and London, UK: Harvard University Press.

Knorr-Cetina, K. (1995). Laboratory studies: The cultural approach to the study of science. In Handbook of science and technology studies (pp. 140-166). London: Sage Publications.

Knorr-Cetina, K. (1999). Epistemic cultures: How the sciences make knowledge. Cambridge, MA: Harvard University Press.

Kruse, C. (2016). The social life of forensic evidence. Oakland, CA: University of California Press.

Latour, B. (2005). Reassembling the social. An introduction to actor-network-theory. Oxford: Oxford University Press.

Lawless, C. (2011). Policing markets: The contested shaping of neo-liberal forensic science. British Journal of Criminology, 51(4), 671-689. https://doi. org/10.1093/bjc/azr025

Lynch, M. (1993). Scientific practice and ordinary action: Ethnomethodology and social studies of science. New York: Cambridge University Press.

Lynch, M. (1998). The discursive production of uncertainty: The OJ Simpson 'Dream Team' and the sociology of knowledge machine. Social Studies of Science, 28(5-6), 829-868.

Lynch, M. (2013). Science, truth, and forensic cultures: The exceptional legal status of DNA evidence. Studies in History and Philosophy of Biological and Biomedical Sciences, 44(1), 60-70. https://doi.org/10.1016/j.shpsc.2012. 09.008

Lynch, M., Cole, S., McNally, R., \& Jordan, K. (2008). Truth machine: The contentious history of DNA fingerprinting. Chicago: University of Chicago Press.

Lynch, M., \& Jasanoff, S. (1998). Contested identities: Science, law and forensic practice. Social Studies of Science, 28(5-6), 675-686. https://doi. org/10.1177/030631298028005001

Machado, H., \& Granja, R. (2018). Ethics in transnational forensic DNA data exchange in the EU: Constructing boundaries and managing controversies. Science as Culture, 27(2), 242-264. https://doi.org/10.1080/09505431. 2018.1425385

Machado, H., \& Prainsack, B. (2012). Tracing technologies: Prisoners' views in the era of CSI. Farnham, UK: Ashgate.

Machado, H., \& Silva, S. (2019). What influences public views on forensic DNA testing in the criminal field? A scoping review of quantitative evidence. Human Genomics, 13(1), 23. https://doi.org/10.1186/s40246-019-0207-5

Nuffield Council on Bioethics. (2007). The forensic use of bioinformation: Ethical issues. London.

Porter, T. M. (1995). Trust in numbers: The pursuit of objectivity in science and public life. Princeton, NJ: Princeton University Press. 
Quinlan, A. (2014). Studying DNA: Envisioning new intersections between feminist methodologies and actor-network theory. In A. Tatnall (Ed.), Technological advancements and the impact of actor-network theory (pp. 196-208). Hershey, PA: IGI-Global. https://doi.org/10.4018/978-1-4666-6126-4.ch011

Ritzer, G. (1992). Sociological theory. Singapore: Mc-Graw Hill International Editions.

Santos, F. (2014). Making sense of the story: The dialogues between the police and forensic laboratories in the construction of DNA evidence. New Genetics and Society, 33(2), 181-203. https://doi.org/10.1080/14636778.2014. 916186

Santos, F. (2017). The transnational exchange of DNA data: Global standards and local practices. In K. Jakobs \& K. Blind (Eds.), Proceedings of the $22 n d$ EURAS annual standardisation conference. Digitalisation: Challenge and opportunity for standardisation (pp. 305-322). Aachen: Verlag Mainz.

Shapin, S. (1986). The Social history of truth. Chicago: Chicago University Press.

Skinner, D. (2013). "The NDNAD has no ability in itself to be discriminatory": Ethnicity and the governance of the UK National DNA Database. Sociology, 47(5), 976-992. https://doi.org/10.1177/0038038513493539

Stackhouse, R., Anderson, C., Shaw, A., \& Iredale, R. (2010). Avoiding the "usual suspects": Young people's views of the National DNA Database. New Genetics and Society, 29(2), 149-166. https://doi.org/10.1080/14636778.2010. 484234

Timmermans, S., \& Berg, M. (1997). Standardization in action: Achieving local universality through medical protocols. Social Studies of Science, 27(2), 273305. https://doi.org/10.1177/030631297027002003

Weber, M. (1949). The methodology of social sciences. New York: Free Press.

Wienroth, M. (2018). Socio-technical disagreements as ethical fora: Parabon NanoLab's forensic DNA Snapshot ${ }^{\mathrm{TM}}$ service at the intersection of discourses around robust science, technology validation, and commerce. BioSocieties, 1-18. https://doi.org/10.1057/s41292-018-0138-8

Williams, R., \& Johnson, P. (2004). "Wonderment and dread": Representations of DNA in ethical disputes about forensic DNA databases. New Genetics and Society, 23(2), 205-223. https://doi.org/10.1080/1463677042000237035

Williams, R., \& Johnson, P. (2008). Genetic policing: The use of DNA in criminal investigations. Cullompton: Willan Publishing.

Wilson-Kovacs, D., Wyatt, D., \& Hauskeller, C. (2012). “A Faustian bargain?” Public voices on forensic DNA technologies and the National DNA Database. New Genetics and Society, 31(3), 285-298. Retrieved from http://www.tandfonline.com/doi/abs/10.1080/14636778.2012.687085 
Open Access This chapter is licensed under the terms of the Creative Commons Attribution 4.0 International License (http://creativecommons.org/licenses/ by $/ 4.0 /$ ), which permits use, sharing, adaptation, distribution and reproduction in any medium or format, as long as you give appropriate credit to the original author(s) and the source, provide a link to the Creative Commons licence and indicate if changes were made.

The images or other third party material in this chapter are included in the chapter's Creative Commons licence, unless indicated otherwise in a credit line to the material. If material is not included in the chapter's Creative Commons licence and your intended use is not permitted by statutory regulation or exceeds the permitted use, you will need to obtain permission directly from the copyright holder.

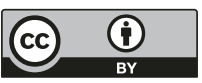




\title{
Biological Explanations of Criminal Behaviour
}

\begin{abstract}
This chapter provides a historical and sociological overview of the biological explanations for violent and criminal behaviour. It starts with a detailed description of the seminal work by Cesare Lombroso (nineteenth century) and highlights the risks of biological determinism and the potential stigmatization raised by this line of research. It then discusses current trends of biologization and genetization of crime, by focusing on the specific studies in the fields of epigenetics and neurobiology.

The chapter aims to provide the reader with a critical reading of such trends through the lens of sociology. Specifically, it is outlined how previous and current biological and biosocial explanations of criminal behaviour can foster risks such as exclusion, marginalization and stigmatization and support notions of citizenship that differentiate between citizens who should be protected and those who should be monitored.
\end{abstract}

Keywords Biological determinism • Biogenetics • Epigenetics • Neurobiology $\bullet$ Stigmatization $\bullet$ Nature $\bullet$ Nurture 


\section{Biological Determinism: The Work of Cesare LOMBRoso}

Cesare Lombroso (1835-1909), the psychiatrist who was the father of criminal anthropology, marked indelibly the history and trajectory of biological explanations for criminal behaviour. Two distinctive features typify Lombroso's positivist approach: the first one is linked to a commitment towards collecting data through empirical observation. The collection of body measurements, such as weight, height and relative proportion of several body parts, was aimed at producing knowledge based upon alleged numerical objectivity (Rose \& Abi-Rached, 2013, p. 170). The second distinctive feature of Lombroso's approach is connected to the premise that propensity for crime is inscribed in individual biology (Walklate, 2007). According to the author's approach, this means that propensity for crime can be identified through "visible marks of criminality" that materialize in physical, moral, degenerative and unalterable features (Cole, 2001; Horn, 2003; Rose, 2000).

In the publications L'Uomo Delinquente (1876, “The Criminal Man”) and Le Crime, causes et remèdes (1899, "Crime, Its Causes and Remedies"), which are based on studies influenced by Darwin's natural selection theories, Lombroso defends that "criminals" are characterized by biological inferiority and possess "atavistic" physical and psychological traits that show physical and psychological "atavism" of a hereditary nature. Such traits are considered as being reminiscent of the earlier stages of human evolution (Dunnage, 2018; Newburn, 2007; Twine, 2002; Walklate, 2007). Based upon such principles, the author outlines the features of an "ideal-type" of "born criminal", that is, someone biologically predisposed for criminal activities. Among the physical traits listed by Lombroso we can find the "abnormal" shape or size of the skullcap and face, thick eyebrows, prominent molars, big, deformed ears, bodily dissymmetry and large size of arms, hands and feet. In terms of behaviour and personality traits, Lombroso argues that these individuals are characterized by reduced sensibility to pain, cruelty, recklessness, aversion to work, instability, vanity, penchant for superstition and sexual precociousness. This way, Lombroso sketches a general portrait for criminals anchored in implicit and explicit assumptions about biological traits that are conceived as being independent of specific historical, social or political context (Klein, 2013, p. 195; Smart, 1995). 
The scientific and political implications of this approach were extensive in their impact and reach. According to the postulates of criminal positivism, if an individual's criminal behaviour can be determined by innate individual traits, the goal of the justice system must be the incapacitation and treatment of these individuals until they are no longer a threat to society (Walklate, 2007). This type of logic framed the eugenic strategies that proliferated in the US and Europe towards the end of the nineteenth century and beginning of the twentieth century (Aungles, 1990; Duster, 2003; Rose, 2000), involving initiatives such as permanent segregation, marriage restrictions, restrictive immigration policies and compulsory sterilization (Newburn, 2007).

Eugenic strategies formed a movement with multiple modalities and a very questionable history, partly due to the association with the eugenic philosophies adopted by the Nazis in 1930 (Newburn, 2007). Following that kind of repercussion, biological theories about criminal behaviour received harsh criticism and became controversial, which pushed them to the outskirts of the scientific community and consigned them, for many years, to become synonym with scientific obscurantism (Machado, 2015).

\section{Biogenetic Explanations of Criminal Behaviour}

Notwithstanding the numerous controversies that have dogged the postulates of biological determinism, since the 1980s there has been a growing trend to reinvigorate and legitimize studies that put biology and genetics at the forefront (Baker, Tuvblad, \& Raine, 2010; Mednick, Moffitt, \& Stack, 1987; Walsh \& Beaver, 2009). Trying to move away from the pernicious implications of approaches based upon the biological determinism defended by Lombroso and some of his successors, the reinvigoration of biogenetic explanations for criminal behaviour is sustained by features that differ from the perspectives that precede them. A few guiding principles stand out in this regard. The first one refers to a focus on violent behaviour and criminal practices, considered by the scientific community as the most "likely" to be influenced by biological factors. Within this context, the potential usefulness of investigating epidemiological strategies in terms of public health was defended (Akers \& Lanier, 2009; Lanier, 2010), in particular those aiming to calculate the risk of being biologically predisposed for criminality (Raine, 2013).

Therefore, the locus where the interest resides moves from looking for the criminal or aggressive genes towards identifying, intervening, taking 
precautions and preventing risks, in order to identify vulnerabilities liable to increase an individual's propensity for violent conduct (Rose \& AbiRached, 2013). As shown by Nikolas Rose and Joelle Abi-Rached, this kind of approach is perfectly in line with our current socio-political juncture, where crimes are not just seen as infractions but also as public safety problems, generating economic burdens. In the author's words:

Within these control strategies of precaution, prevention and pre-emption, the question shifts from that of response to the offense after the act, to programmes of prediction and prevention that identify those at risk of the basis of a kind of algorithm that combines genetic and neurobiological factors with those relating to family life, parental behaviour, poverty, housing and other environmental factors. For these violent or impulsive behaviours at least, crime, is reframed as a problem of public health. (Rose \& Abi-Rached, 2013, p. 190) [added italics]

The reinvigoration of biogenetic explanations for criminal behaviour is closely linked to the emergence and consolidation of genetics and neuroscience. These new sciences, imbued with significant symbolic power, are able to lend scientific relevance to the studies aiming to turn human biology into a readable entity (Pavlich, 2009; Rose, 2000; Twine, 2002; Walby \& Carrier, 2010). There has been, however, an important shift: in the nineteenth century, the focus resided at the molar body, which was visible, tangible and easily revealed to the gaze of the experts. Nowadays, however, the focus on the body has been supplemented by the molecular level. A multitude of increasingly sophisticated biometric technologies and visualization devices nowadays renders the interior of the organic body readable while simultaneously allowing to decompose, anatomize, manipulate and amplify it at the molecular level (Rose, 2001, 2007). One example of a biometric technology that aims to render criminal bodies as readable is forensic DNA phenotyping that will be addressed in Chap. 7 of this book.

The proliferation of new technologies aimed at reading the body thus consolidates a new ontology of bodily datafication (French \& Smith, 2016; Hindmarsh \& Prainsack, 2010; Kloppenburg \& van der Ploeg, 2018; Smith, 2016). This specific ontology is based on the notion that the reading of the body may provide an objective and indisputable source of truth about a person's identity (Aas, 2006; Kloppenburg \& van der Ploeg, 2018). 
Finally, another guiding principle of this reinvigorated wave of studies that interlinks biology and criminality is its inscription into perspectives which conjugate genetic elements with social environments and the individual's psychological traits (Walsh \& Beaver, 2009) - a theme to be addressed in detail in the next section of this chapter.

\section{Nature (Versus) Nurture}

Epigenetics is one of the recent trends which most clearly illustrates the articulation between biogenetic and social aspects. In brief, epigenetics is a new post-genomic field of research, which has been growing and developing at an accelerated rate. It studies the molecular mechanisms regulating the roles of genes without altering the DNA sequence. The main principles underlying this field of research convey the idea that epigenetic mechanisms are: (1) sensible to environmental factors and lifestyles-in other words, instead of being determined exclusively endogenously, biological systems have enough flexibility to react to environmental changes (Loi, Del Savio, \& Stupka, 2013, p. 143); (2) established at an early development stage, with effects that can manifest themselves on a lifelong basis; (3) potentially transferable to subsequent generations (Hedlund, 2012; Loi et al., 2013); (4) possibly reversible through pharmacological and/or behavioural interventions (Tremblay \& Szyf, 2010).

Although most investigations in the field of epigenetics are based upon incipient scientific discoveries, performed on animals and under experimental conditions, there is a significant eagerness to extrapolate the preliminary results to human behaviour (Richardson, 2015). Both the scientific community and popular culture have shown a marked interest in the potential uses of this field of post-genomic research in terms of public health (Meloni \& Testa, 2014).

Nevertheless, attitudes and reactions regarding the potential held by epigenetics are subdivided. On the one hand, some researchers consider epigenetics as a new way of thinking that recognizes the importance of social aspects. On the other hand, others have remained sceptical on whether this new approach entails less biocentrism or if it is a cloaked way to reproduce "simple" biological explanations for complex social issues (Lloyd \& Müller, 2018, pp. 675-676). Within the scope of this second position, some authors have alerted to the fact that epigenetic approaches may come to constitute new types of biological determinism (Richardson, 
2015). As outlined by Stephanie Lloyd and Ruth Müller, "environmental epigenetics might also engender novel forms of biological essentialism, particularly if epigenetic modifications are framed as permanent bodily marks that determine the potentials of individuals and groups who have been exposed to potentially 'harmful' environments" (Lloyd \& Müller, 2018, p. 676).

The study of criminal behaviour is one of the fields where the contributions of epigenetics have been more readily "absorbed". Richard E. Tremblay is one of the most influential authors in this field, a psychology professor at the University College Dublin who was labelled as "the accidental epigeneticist" by Nature (Hall, 2013). After developing, over the course of several years, longitudinal studies with pre-school children evidencing aggressive behaviour and coming to the conclusion that disruptive behaviours are more significant in the earliest infancy stages, Richard Tremblay began working with Moshe Szyf, a geneticist and professor of pharmacology and therapeutics at McGill University. Together, the two academics created an approach that explores the development of chronic aggressive behaviours through epigenetics (Tremblay \& Szyf, 2010).

In brief, Tremblay and Szyf defend that epigenetic marks, modulated by the environment and by how children are nurtured by their mothers during the prenatal period and immediately following the birth, are fundamental to define the level of predisposition towards aggressive behaviour. The moment of conception and even that of preconception are, therefore, focal points of interest, where mothers are considered as the fundamental agents who will determine children's future behaviours. Among the risk factors specifically connected to mothers, the two authors listed the following: pregnancy at a young age, history of behavioural issues, reduced educational resources, consumption habits of tobacco, alcohol and other substances, mental health issues, problematic intimate relationships, poverty and coercive motherhood (Tremblay, 2010; Tremblay \& Szyf, 2010).

Tremblay and Szyf defend the creation and implementation of strategies for precocious and intergenerational prevention with women. The defence of this highly controversial point of view is based, according to the authors, on presupposing that women who possess a few, or all, of these risk factors will be more prone to have children who will subsequently develop aggressive behaviours. Thus, according to the authors, society 
must invest in intensive perinatal interventions to apply preventive and corrective measures to women of specific groups. According to Richard Tremblay:

The evidence suggests that preventing the development of serious disruptive behaviour problems should start at conception, at the latest, and needs to target females who have a history of social adjustment problems. In essence we need to turn on its head our thinking about prevention of disruptive behaviour: males are much more affected, but females should be our prime target to prevent a new generation of males and females with disruptive behaviour. (Tremblay, 2010) [added italics]

Construing the mothers' bodies as "epigenetic vectors" will lead to strategies liable to increase the already high levels of control applied to the female body (Richardson, 2015). Moreover, as evidenced by the quote above, the category "women" does not simply emerge monolithically from the epigenetic approach: this perspective is focused on women from disadvantaged social backgrounds, which intersecting with class, race, age and ethnicity, face specific patterns of oppression and discrimination (Andersen \& Collins, 2004; Burgess-Proctor, 2006; Weber, 2001). This shows the discriminatory and invasive potential of these approaches among more vulnerable social groups, as they expand, in terms of impact and reach, the type of social control applied to the reproductive female body (Richardson, 2015; Richardson et al., 2014).

However, this kind of reconfiguration of collective and individual responsibility is not restricted to recent epigenetic approaches (Meloni \& Testa, 2014; Pickersgill, Niewöhner, Müller, Martin, \& CunninghamBurley, 2013; Richardson, 2015). By analysing the trajectory of neuroscience when trying to explain criminal behaviours, Nikolas Rose and Joelle Abi-Rached (2013) show why there is a growing tendency to defend the connection between child deprivation, cerebral development and future behavioural problems, particularly if we follow the assumption that a child's brain is malleable, and therefore very influenced by the objective conditions of his life. Some authors have argued that children who suffered from neglect during their infancy are more prone to develop antisocial behaviours in later stages of their lives (Perry, 2002, 2009). As noted by Rose and Abi-Rached, over time and through different sources of legitimacy, the family is indicated as the epicentre for the development of criminal behaviour: 
We find the repeated arguments that one should minimize the host of social ills, including criminal and antisocial conduct, by governing the child through its family. [...] Social justice, it seems, lies not in tackling the causes of structural inequality, poverty, poor housing, unemployment, and the like, but in managing parents in the name of the formation of good citizens. (Rose \& Abi-Rached, 2013, p. 196)

This type of approach, which puts the family as the cornerstone to explain criminal behaviour, configures new models for biocitizenship. On the one hand, as they allow the body of certain individuals to be construed as a menace to public health and safety. On the other hand, by underlining the potentially hereditary of predisposition towards aggressive and criminal behaviour, these approaches also construe entire families as potential threats. Underlying to this line of action is the emergence of the concept of "anti citizen", in other words, individuals categorized as biologically predisposed to risks, and towards whom it is justifiable to apply a set of control and monitoring activities and policies, even if they do not present any evidence of deviant or criminal behaviour (Rose, 2000, p. 17).

\section{Concluding Remarks}

Despite being consigned to obscurity and considered as "bad science" for many years, the reinvigoration of biogenetic approaches to criminal behaviour is presently an unavoidable milestone in the current framework of the governance of crime. Such a tendency is symptomatic of the genetization, molecularization and biologization of our contemporary society.

Within the scope of current studies, which are increasingly focused on body datafication ontologies, we seem to be witnessing a blurring of the boundaries between nature and nurture. Notwithstanding, we can also see how the symbolic power of genetics and technology have the potential to configure new kinds of biological determinism that may expand and increase, both in their impact and reach, the marginalization of certain social groups. Such groups are outlined according to social categories of gender, race and class, which are then confronted with biogenetic approaches that differentiate between law-abiding citizens, who should be protected, and anti-citizens, immediately monitored and controlled since they are in their mother's womb. 


\section{REFERENCES}

Aas, K. F. (2006). "The body does not lie": Identity, risk and trust in technoculture. Crime, Media, Culture, 2(2), 143-158. https://doi.org/10.1177/ 1741659006065401

Akers, T. A., \& Lanier, M. M. (2009). "Epidemiological criminology": Coming full circle. American Journal of Public Health, 99(3), 397-402. https://doi. org/10.2105/AJPH.2008.139808

Andersen, M. L., \& Collins, P. H. (2004). Race, class, and gender. Belmont, CA: Wadsworth.

Aungles, A. (1990). The home and the prison. University of Wollongong. Retrieved from http://ro.uow.edu.au/theses/1730

Baker, L., Tuvblad, C., \& Raine, A. (2010). Genetics and crime. In The $S A G E$ handbook of criminological theory (Vol. 262, pp. 21-40). London: Sage Publications

Burgess-Proctor, A. (2006). Intersections of race, class, gender, and crime: Future directions for feminist criminology. Feminist Criminology, 1(1), 27-47. https://doi.org/10.1177/1557085105282899

Cole, S. (2001). Suspect identities: A history of fingerprinting and criminal identification. Harvard: Harvard University Press.

Dunnage, J. (2018). The work of Cesare Lombroso and its reception: Further contexts and perspectives. Crime, Histoire \& Sociétés/Crime, History \& Societies, $22(2), 5-8$.

Duster, T. (2003). Backdoor to engenics. New York: Routledge.

French, M., \& Smith, G. (2016). Surveillance and embodiment: Dispositifs of capture. Body \& Society, 22(2), 1-25. https://doi.org/10.1177/1357 $034 \times 16643169$

Hall, S. S. (2013). Behaviour and biology: The accidental epigeneticist. Nature, 505(January), 14-17. https://doi.org/10.1038/505014a

Hedlund, M. (2012). Epigenetic responsibility. Medicine Studies, 3(3), 171-183. https://doi.org/10.1007/s12376-011-0072-6

Hindmarsh, R., \& Prainsack, B. (Eds.). (2010). Genetic suspects: Global governance of forensic DNA profiling and databasing. Cambridge: Cambridge University Press.

Horn, D. G. (2003). The criminal body: Lombroso and the anatomy of deviance. New York: Routledge.

Klein, D. (2013). The etiology of female crime. In E. McLaughlin \& J. Muncie (Eds.), Criminological perspectives. A reader (pp. 195-226). London: Sage Publications.

Kloppenburg, S., \& van der Ploeg, I. (2018). Securing identities: Biometric technologies and the Enactment of human bodily differences. Science as Culture, 1-20. https://doi.org/10.1080/09505431.2018.1519534 
Lanier, M. (2010). Epidemiological criminology (EpiCrim): Definition and application. Journal of Theoretical and Philosophical Criminology, 2(1), 63-103.

Lloyd, S., \& Müller, R. (2018). Situating the biosocial: Empirical engagements with environmental epigenetics from the lab to the clinic. BioSocieties, 13(4), 675-680. https://doi.org/10.1057/s41292-017-0094-8

Loi, M., Del Savio, L., \& Stupka, E. (2013). Social epigenetics and equality of opportunity. Public Health Ethics, 6(2), 142-153. https://doi.org/10.1093/ phe/pht019

Machado, H. (2015). Genética e suspeição criminal: reconfigurações atuais de coprodução entre ciência, ordem social e controlo. In F. Cláudia \& H. Machado (Eds.), Ciência, identificação e tecnologias de governo. Rio Grande do Sul: Coleções Editoriais do CEGOV, 38-55. https://estudogeral.sib.uc.pt/bitstream/10316/41096/1/Gen\%c3\%a9tica\%20e\%20suspei\%c3\%a7\%c3\% a3o\%20criminal.pdf.

Mednick, S. A., Moffitt, T. E., \& Stack, S. A. (1987). The causes of crime: New biological approaches (S. A. Mednick, T. E. Moffitt, \& S. A. Stack, Eds.). Cambridge: Cambridge University Press. https://doi.org/10.2307/2071970 Meloni, M., \& Testa, G. (2014). Scrutinizing the epigenetics revolution. BioSocieties, 9(August), 1-26. https://doi.org/10.1057/biosoc.2014.22

Newburn, T. (2007). Criminology. Cullompton, Devon: Willan Publishing.

Pavlich, G. (2009). The subjects of criminal identification. Punishment \& Society, 11(2), 171-190. https://doi.org/10.1177/1462474508101491

Perry, B. D. (2002). Childhood experience and the expression of genetic potential: What childhood neglect tells us about nature and nurture. Brain and Mind, 3, 79-100.

Perry, B. D. (2009). Examining child maltreatment through a neurodevelopmental lens: Clinical applications of the neurosequential model of therapeutics. Journal of Loss and Trauma, 14(4), 240-255. https://doi.org/10.1080/ 15325020903004350

Pickersgill, M., Niewöhner, J., Müller, R., Martin, P., \& Cunningham-Burley, S. (2013). Mapping the new molecular landscape: Social dimensions of epigenetics. New Genetics and Society, 32(4), 429-447. https://doi.org/10.1080 /14636778.2013.861739

Raine, A. (2013). The anatomy of violence: The biological roots of crime. New York: Random House.

Richardson, S. (2015). Maternal bodies in the postgenomic order. In S. S. Richardson \& H. Stevens (Eds.), Postgenomics: Perspectives on biology after the genome (pp. 210-231). Durham and London: Duke University Press.

Richardson, S., Daniels, C. R., Gillman, M. W., Golden, J. L., Kukla, R., Kuzawa, C., \& Rich-Edwards, J. (2014). Society: Don't blame the mothers. Nature, 512, 131-132. https://doi.org/10.1038/512131a 
Rose, N. (2000). The biology of culpability: Pathological identity and crime control in a biological culture. Theoretical Criminology, 4(1), 5-34. https://doi. org/10.1177/1362480600004001001

Rose, N. (2001). The politics of life itself. Theory, Culture \& Society, 18(6), 1-30.

Rose, N. (2007). The politics of life itself: Biomedicine, power, and subjectivity in the twenty-first century. Princeton: Princeton University Press.

Rose, N., \& Abi-Rached, J. (2013). Neuro: The new brain sciences and the management of the mind. Princeton, NJ: Princeton University Press.

Smart, C. (1995). Law, crime and sexuality: Essays in feminism. London: Sage Publications.

Smith, G. (2016). Surveillance, data and embodiment: On the work of being watched. Body \& Society, 22(2), 108-139. https://doi.org/10.1177/1357 $034 \mathrm{X} 15623622$

Tremblay, R. E. (2010). Developmental origins of disruptive behaviour problems: The "original sin" hypothesis, epigenetics and their consequences for prevention. Journal of Child Psychology and Psychiatry and Allied Disciplines, 51(4), 341-367. https://doi.org/10.1111/j.1469-7610.2010.02211.x

Tremblay, R. E., \& Szyf, M. (2010). Developmental origins of chronic physical aggression and epigenetics. Epigenomics, 2(4), 495-499. https://doi. org/10.2217/epi.10.40

Twine, R. (2002). Physiognomy, phrenology and the temporality of the body. Body \& Society, 8(1), 67-88. https://doi.org/10.1177/1357034X02008 001004

Walby, K., \& Carrier, N. (2010). The rise of biocriminology: Capturing observable bodily economies of 'criminal man'. Criminology \& Criminal Justice, 10(3), 261-285. https://doi.org/10.1177/1748895810370314

Walklate, S. (2007). Understanding criminology: Current theoretical debates (3rd ed.). New York: Open University Press.

Walsh, A., \& Beaver, K. M. (2009). Biosocial criminology. In M. D. Krohn, A. J. Lizotte, \& G. P. Hall (Eds.), Handbook on crime and deviance (pp. 79-101). Dordrecht, Heidelberg, London, New York: Springer. Retrieved from https:// link.springer.com/content/pdf/10.1007\%2F978-1-4419-0245-0_5.pdf

Weber, L. (2001). Understanding race, class, gender, and sexuality: A conceptual framework. Boston: McGraw-Hill. 
Open Access This chapter is licensed under the terms of the Creative Commons Attribution 4.0 International License (http://creativecommons.org/licenses/ by $/ 4.0 /$ ), which permits use, sharing, adaptation, distribution and reproduction in any medium or format, as long as you give appropriate credit to the original author(s) and the source, provide a link to the Creative Commons licence and indicate if changes were made.

The images or other third party material in this chapter are included in the chapter's Creative Commons licence, unless indicated otherwise in a credit line to the material. If material is not included in the chapter's Creative Commons licence and your intended use is not permitted by statutory regulation or exceeds the permitted use, you will need to obtain permission directly from the copyright holder.

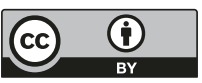




\title{
DNA Technologies in Criminal Investigation and Courts
}

\begin{abstract}
DNA profiling has been assuming a prominent role in the activities of the criminal justice system. Genetic technologies support criminal investigations, while also being seen as holding a highly valuable potential for producing evidence to be used in courts. This chapter has two main objectives: on the one hand, to describe and explain the ways that DNA technologies can be used in criminal investigation and turned into DNA evidence in criminal proceedings; on the other hand, this chapter aims to systematize the main lines of academic literature within the social sciences which have been developed to study the social implications and transformations of cultures and professional practices arising from the presence of DNA technology in the criminal justice system. Besides, the chapter also pays particular attention to the social nature of the high expectations associated to the "infallibility" of DNA technologies and how the media portrays the use of forensic genetics and further exacerbates such notions.
\end{abstract}

Keywords Chain of custody $\bullet$ Criminal investigation $\bullet$ Courts $\bullet$ Infallibility myth $\bullet$ CSI effect 


\section{DNA Technologies and Its Application in Criminal INVESTIGATION}

There is now a broad consensus that DNA technologies play a vital role in justice systems in various regions of the world (Hindmarsh \& Prainsack, 2010; Kruse, 2016; Lawless, 2016; Lynch, Cole, McNally, \& Jordan, 2008; Toom, 2018; Williams \& Johnson, 2008). DNA technologies support the collection of information that helps the criminal investigation, and DNA evidence is considered to have great value for judicial procedures.

However, the aura of infallibility associated with DNA technologies generates expectations which are often exaggerated and dissociated from the concrete reality of criminal investigation. It is therefore essential to recognize and identify the potential risks arising from the use of DNA technology, in order to prevent possible errors and threats to civil rightsincluding upholding the presumption of innocence, genetic privacy and the moral and physical integrity of suspects or persons accused of crimes (McCartney, 2006; Murphy, 2007; Nuffield Council on Bioethics, 2007).

Identification of individuals using DNA profiles is often described as the most important discovery in the world of forensic science since the fingerprint (Lynch et al., 2008) and has even been designated by several authors as the most significant mean of human identification of the modern era. Development of studies on the use of DNA for individual identification depends upon broad zones that exist between the genes that are generally called "non-coding DNA". These intergenic zones reveal specific chemical sequences that are supposed to be unique to each individual and therefore produce a "genetic fingerprint". Comparison of different "genetic fingerprints" enables us to observe whether different samples of DNA come from the same individual or different individuals. There is also a biological relationship of descendance between the suppliers of different samples that might be compared. In short, each person's DNA is unique, except in the case of identical twins.

A new epistemology of forensic identification (Cole, 2009) claims that it is impossible to achieve "perfect" individualization, and therefore, we should speak about probabilities rather than certainties (Kaye, 2009; Saks \& Koehler, 2008). Scientific authorities generally argue that absolute individualization is a theoretical goal, but even excluding identical twins, the inclusion of more markers in a DNA profile analysis leads to an increased likelihood of observation of somatic mutations, that is, intra-individual heterogeneity (Amorim, 2002). 
Forensic DNA analysis usually involves comparisons between genetic profiles extracted from biological samples collected from a specific site, object or person which is thought to be associated to a crime, in order to determine the likelihood that such samples come from a particular person (e.g., from a suspect, or victim, of a specific crime). Biological substances collected at crime scenes - such as blood, hair, semen, urine, skin, saliva, sweat and tears-all contain DNA. A DNA sample can also be obtained through a mouth smear from an identified person, or by collecting hair samples (including hair roots, since they contain the cells needed for analysis), blood samples (usually achieved nowadays by pricking the finger) or by scraping part of the body to remove a small sample of a person's skin.

A molecular biological technique, called polymerase chain reaction (PCR) is fundamental for analysing DNA polymorphisms. This technique makes it possible to replicate in vitro and amplify and analyse trace amounts of DNA. Nowadays, this technique is frequently used in the preparation of DNA profiles for criminal identification and makes it possible to pair suspects with blood, hair, saliva or sperm samples. DNA profiles are also often used for forensic civilian identification purposes, in particular for paternity testing and identification of missing persons and human remains (Bier, 2018; Smith, 2017; Toom, 2017).

A technical problem raised by DNA profiles is the fact that contamination with DNA from an outside source can occur, both at the time of collection and in the scientific laboratory. Contamination of the DNA sample is frequent in crime scenes, in old and degraded samples, in corpses and human remains. False identifications are likely to happen when used in partial profiles due to insufficient quantity or degradation of DNA (Murphy, 2007).

In addition to the aforementioned risks, there are ethical issues that derive from the type of information that can be obtained from DNA analysis. While traditional fingerprints only reveal a person's identity, samples used for DNA profiles may reveal much more information, namely about the individual's kinship ties, which may be unknown to the individual (Haimes, 2006; Kim, Mammo, Siegel, \& Katsanis, 2011). With advances in the knowledge of the human genome, even the so-called non-coding DNA may in the future be associated with sensitive information, such as diseases and behavioural traits (Duster, 2003; Williams \& Johnson, 2004a).

The myth of the infallibility of genetic identification can condition the conduct of the police investigation itself and the assessment of evidence in court. Hence, it is desirable to question the reliability and scope of the 
DNA evidence and the consideration of the circumstances associated with each case. It is, therefore, necessary to guarantee the principle of taking precautions when using DNA profiling as a means of evidence, since in certain circumstances it may become controversial and maybe a source of abuse and judicial errors (Gill, 2014, 2016; Schiffer \& Champod, 2008).

\section{From the Crime Scene to the Laboratory AND THE COURT}

The presence of DNA technology in the criminal justice system involves multiple professionals and differentiated spaces. Within the framework of the so-called chain of custody, the focus is on the crime scene and its observation to identify and collect biological traces that may subsequently be useful for identifying a perpetrator. Subsequently, the biological traces are analysed in a laboratory context. Finally, scientific reports on the DNA analysis are presented to the persons responsible for judging the case in court.

Social science studies have revealed that, in an initial stage, various controversies arose, associated to doubts about the credibility and robustness of DNA technology that accompanied the start of its practical applications in human identification (Aronson, 2007; Jasanoff, 1995; Lynch \& Jasanoff, 1998). However, DNA testing gained a more respected status due to its unparalleled capacity to identify criminal suspects (Lynch et al., 2008; Williams \& Johnson, 2008). As Michael Lynch argues, DNA testing is treated "as both the source and object of an extraordinary and even absolute, degree of certainty in criminal law" (Lynch, 2013, p. 60).

Claims for the operational utility and scientific standing of forensic DNA profiling are often made in the context of new concepts and methods designed to improve the quality and effectiveness of police criminal investigation practices (Williams \& Johnson, 2008). Therefore, forensic DNA evidence is often viewed as capable of enhancing police practices with some degree of "objectivity" associated with the scientific authority of DNA technologies (Cole \& Lynch, 2006; Costa, 2017; Santos, 2014). However, studies with police forces reveal that police professionals consider that DNA testing is subject to various contingencies, which is why it should be seen primarily as a source of intelligence, to be taken into account in criminal investigation in conjunction with other types of leads and evidence (Huey, 2010; Machado \& Granja, 2019). 
In short, as the anthropologist Corinna Kruse (2016) points out in her study about the Swedish justice system, the views and uses of DNA evidence tend to vary. The different professionals who are involved in investigating crimes and taking decisions on whether suspects should be accused or exonerated, construct different meanings and interpretations regarding the value of forensic genetics. The author illustrates the multiplicity of meanings attributed to DNA testing by different professionals, as follows:

To a crime scene technician, forensic evidence is something that can be produced by traces $(\ldots)$ from a crime scene. To a police investigator, forensic evidence is something that may be able to help him or her to assess a person's narrative. To a forensic scientist, forensic evidence is a trace that is to be analysed and evaluated (...) To a prosecutor, forensic evidence is something that will help him or her to convince the court of a defendant's culpability. And to a judge, forensic evidence is something reliable, an anchoring point in their assessment of a case. (Kruse, 2016, pp. 155-156)

Rather than serving as a machine for generating truth, DNA evidence relates to the expectations, epistemic cultures (Knorr-Cetina, 1999) and objectives of each social and professional group. There is no uniform and absolute perception of what DNA technologies can achieve in terms of criminal investigation: the expectations of a criminal investigator are distinct from the convictions of a scientist or from that which is expected from judges, lawyers, jurors or even from convicts. The presence of DNA technology also brings different traditions, cultures, languages and procedures into interaction: it immediately places into dialogue-and tensionscience and law (Edmond, 2001; Jasanoff, 2006). While science aims to convey "neutral" and "objective" knowledge, the intrinsic mission of the legal system is to try to establish the "truth of facts" based on scientific evidence and decide on the guilt or innocence of a person accused of committing a crime. In short, a DNA profile is subject to a transformative and contingent process that involves several actors, practices and organizational structures. To achieve the status as credible and robust, DNA evidence is subject to a series of events that highlight technical-scientific, legal and bureaucratic procedures, which sociologist Michael Lynch and his colleagues (Lynch et al., 2008) have termed "administrative objectivity". 


\section{The CSI Effect and the Associated Risks}

Criminal investigation using the potential of forensic genetics has attracted media attention, fuelling a phenomenon that many people call the "CSI effect". Television representations of criminal investigation focus on technology: the true heroes of police series are no longer detectives but instead forensic identification technologies (Kruse, 2010; Machado \& Prainsack, 2012). DNA evidence assumes a particularly important role in this regard since it symbolizes an ideology in which machines are more reliable and "safer" than human action and knowledge.

Although there is no consensus as to whether or not there is a "CSI effect", and the exact nature of this phenomenon (see Ley, Jankowski, \& Brewer, 2010), it is generally associated with the idea that judges and juries allegedly attribute more weight to evidence obtained through the application of molecular genetic techniques than to other types of evidence. Police stories inspired by DNA technology use cultural images that reflect a dominant idea, which is taken as being accurate and absolute, in relation to the work of researchers and the decisive power of forensic identification techniques - in particular, the perception that DNA evidence offers "infallible evidence". This set of ideas is propagated not only by television crime drama that focuses on the use of forensic science but also by journalists, lawyers and other actors in the justice system, such as judges, public prosecutors and eventually the police officers themselves.

Academic studies of how the media portray the uses of forensic investigation technologies in criminal investigations, and the effects that this coverage may have on different audiences, have increased in recent years. These studies focus especially in the adversarial judicial system, in which jurors and barristers take centre stage: juries (citizens) can decide whether or not the accused (defendants) are guilty, and it is up to the representatives of the parties involved to argue about the validity and meaning of the evidence admitted to trial. The judge often plays the role of a "passive arbitrator", responsible for defining the rules of the trial and whether or not the presented evidence may be admitted.

Existing literature on the alleged CSI effect has mainly discussed the way that television series shape audience perceptions of DNA technology, routine crime scene analysis procedures and the steps used to identify criminal offenders, given that audiences are generally distant from the "real world" of criminal investigation and court work. The main focus of these studies has been on the influence of series such as CSI on the 
respective viewers (Brewer \& Ley, 2010; Schweitzer \& Saks, 2007), on jurors-ordinary citizens summoned by courts to evaluate criminal cases that may be complex and may involve DNA evidence-and also on judges and police investigators themselves (Cole \& Dioso-Villa, 2007; Durnal, 2010; Huey, 2010; Shelton, Kim, \& Barak, 2006).

There is also a study group focusing on how a specific social group, individuals serving prison sentences, views media messages about DNA technology. According to existing studies (Machado \& Prainsack, 2012; Machado, Santos, \& Silva, 2011; Prainsack \& Kitzberger, 2009), prisoners tend to believe that DNA evidence has almost absolute power in terms of identification, based on the idea that the genetic profile is a technology with a probative and criminal identification capability which is far superior to fingerprints. However, the infallibility of DNA technology is not considered to be absolute by these inmates: they accentuate the possibility of human error and harbour strong suspicions of police officers or malicious individuals who may deliberately "plant" biological traces in crime scenes to incriminate them. They have also stated that they fear that the authorities will lie about the existence of DNA evidence to obtain confessions from criminal suspects (Machado et al., 2011).

Another aspect to be noted concerning the consequences that the TV series has on the professionals of the justice system is the concern harboured by the community of forensic scientists in relation to the alleged lack of public literacy. The CSI effect, together with a lack of literacy on the probabilistic framework involved in the interpretation of DNA evidence, is considered by many forensic geneticists to be the major obstacle in their task of communicating the results of DNA analysis to members of the criminal justice system (Amorim, 2012; Amorim et al., 2016). A recent study on the subject, based on the social representations of members of the forensic genetics community in Europe, highlights the scientists' concerns about how the professionals of the justice system and members of the public attribute an excessively "enthusiastic" and "optimistic" value in relation to DNA's capacity as evidence in court cases (Amelung, Granja, \& Machado, 2019). In response to these challenges, there are a few strategies for addressing such risk communication. Some examples include providing concrete models for good practice for evaluative expert reporting and suggesting standards for evaluative reporting within professional networks, such as the European Network of Forensic Science Institutes (ENFSI) (Biedermann, Champod, \& Willis, 2017). 


\section{CONCLUding Remarks}

The risk associated with the use of DNA technologies in the criminal justice system most commonly identified in the literature, in the fields of forensic genetics and the social sciences, regards the myth of the infallibility of genetic identification. Academic research reveals how notions related to the alleged infallibility of DNA technologies can condition the conduct of the police investigation itself, and how evidence is appraised in court. To this effect, it is desirable to question the framework of DNA evidence and consider the circumstances of each specific case. One possible way is to consider that the DNA profile should only be used as a means of backing up other types of evidence, and to safeguard the principle of equal access to evidence, defence and prosecution, as already occurs in most justice systems.

Another risk arising from the use of DNA technology, which should not be dissociated from the myth of its infallibility, concerns the risk of stigmatization arising from social inequalities, which are reproduced as soon as police forces decide to collect a biological sample of certain individuals to the detriment of others. The literature on sociology and criminology has systematically referred to the way that police practices primarily target individuals and communities who are considered to pose risks. This risk of suspicion is directed towards identification and subsequent collection of data (DNA profile and other biometric data) from the most deprived social groups and individuals belonging to so-called ethnic minorities (Chow-White \& Duster, 2011; Cole \& Lynch, 2006; Duster, 2006; Skinner, 2013; Williams \& Johnson, 2004b).

\section{REFERENCES}

Amelung, N., Granja, R., \& Machado, H. (2019). "We are victims of our own success": Challenges of communicating DNA evidence to "enthusiastic". In S. R. Davies \& U. Felt (Eds.), Exploring science communication: A science and technology studies approach. London: Sage.

Amorim, A. (2002). A Espécie das Origens. Genomas, Linhagens e Recombinações. Lisbon: Gradiva.

Amorim, A. (2012). Opening the DNA black box: Demythologizing forensic genetics. New Genetics and Society, 31(3), 259-270. https://doi.org/10.1080 /14636778.2012.687083

Amorim, A., Crespillo, M., Luque, J., Prieto, L., Garcia, O., Gusmão, L., ... Pinto, N. (2016). Formulation and communication of evaluative forensic 
science expert opinion-A GHEP-ISFG contribution to the establishment of standards. Forensic Science International: Genetics, 25, 210-213. https://doi. org/10.1016/j.fsigen.2016.09.003

Aronson, J. (2007). Genetic witness: Science, law, and controversy in the making of DNA profiling. Piscataway, NJ: Rutgers University Press.

Biedermann, A., Champod, C., \& Willis, S. (2017). Development of European standards for evaluative reporting in forensic science: The gap between intentions and perceptions. The International Journal of Evidence os Proof, 21(1-2), 14-29. https://doi.org/10.1177/1365712716674796

Bier, J. (2018). Bodily circulation and the measure of a life: Forensic identification and valuation after the Titanic disaster. Social Studies of Science, 48(5), 635662. https://doi.org/10.1177/0306312718801173

Brewer, P. R., \& Ley, B. L. (2010). Media use and public perceptions of DNA evidence. Science Communication, 32(1), 93-117. https://doi.org/10.1177/ 1075547009340343

Chow-White, P., \& Duster, T. (2011). Do health and forensic DNA databases increase racial disparities? PLoS Medicine, 8(10), el001100. https://doi. org/10.1371/journal.pmed.1001100

Cole, S. (2009). Forensics without uniqueness, conclusions without individualization: The new epistemology of forensic identification. Law, Probability and Risk, 8(3), 1-23. https://doi.org/10.1093/lpr/mgp016

Cole, S., \& Dioso-Villa, R. (2007). CSI and its effects: Media, juries, and the burden of proof. New England Law Review, 41(3), 435-470.

Cole, S., \& Lynch, M. (2006). The social and legal construction of suspects. Annual Review of Law and Social Science, 2, 39-60. https://doi.org/10.1146/ annurev.lawsocsci.2.081805.110001

Costa, S. (2017). Visibilities, invisibilities and twilight zones at the crime scene in Portugal. New Genetics and Society, 36(4), 375-399. https://doi.org/10.108 $0 / 14636778.2017 .1394835$

Durnal, E. (2010). Crime scene investigation (as seen on TV). Forensic Science International, 199(1-3), 1-5. https://doi.org/10.1016/j.forsciint.2010.02.015

Duster, T. (2003). Backdoor to engenics. New York: Routledge.

Duster, T. (2006). The molecular reinscription of race: Unanticipated issues in biotechnology and forensic science. Patterns of Prejudice, 40(4-5), 427-441. https://doi.org/10.1080/00313220601020148

Edmond, G. (2001). The law-set: The legal-scientific production of medical propriety. Science, Technology, \& Human Values, 26(2), 191-226. https://doi. org $/ 10.1177 / 016224390102600204$

Gill, P. (2014). Misleading DNA evidence: Reasons for miscarriages of justice. Amsterdam: Academic Press/Elsevier.

Gill, P. (2016). Analysis and implications of the miscarriages of justice of Amanda Knox and Raffaele Sollecito. Forensic Science International: Genetics, 23, 9-18. https://doi.org/10.1016/j.fsigen.2016.02.015 
Haimes, E. (2006). Social and ethical issues in the use of familial searching in forensic investigations: Insights from family and kinship studies. Journal of Law, Medicine of Ethics, 34(2), 263-276. https://doi.org/10.1111/ j.1748-720X.2006.00032.X

Hindmarsh, R., \& Prainsack, B. (Eds.). (2010). Genetic suspects: Global governance of forensic DNA profiling and databasing. Cambridge: Cambridge University Press.

Huey, L. (2010). "I've seen this on CSI": Criminal investigators' perceptions about the management of public expectations in the field. Crime, Media, Culture, 6(1), 49-68. https://doi.org/10.1177/1741659010363045

Jasanoff, S. (1995). Science at the bar. Law, science, and technology in America. Cambridge, MA and London, UK: Harvard University Press.

Jasanoff, S. (2006). Just evidence: The limits of science in the legal process. Journal of Law, Medicine \& Ethics, 34(2), 328-341. https://doi. org/10.1111/j.1748-720X.2006.00038.x

Kaye, D. H. (2009). Identification, individualization, uniqueness. Law, Probability and Risk, 8(2), 85-94.

Kim, J., Mammo, D., Siegel, M., \& Katsanis, S. (2011). Policy implications for familial searching. Investigative Genetics, 2(1), 1-22. https://doi. org/10.1186/2041-2223-2-22

Knorr-Cetina, K. (1999). Epistemic cultures. How the sciences make knowledge. Cambridge, MA; London, UK: Harvard University Press.

Kruse, C. (2010). Producing absolute truth: CSI science as wishful thinking. American Anthropologist, 112(1), 79-91. https://doi.org/10.1111/ j.1548-1433.2009.01198.x

Kruse, C. (2016). The social life of forensic evidence. Oakland, CA: University of California Press.

Lawless, C. (2016). Forensic science: A sociological introduction. Oxon and New York: Routledge.

Ley, B. L., Jankowski, N., \& Brewer, P. R. (2010). Investigating CSI: Portrayals of DNA testing on a forensic crime show and their potential effects. Public Understanding of Science, 21(1), 51-67. https://doi.org/10.1177/ 0963662510367571

Lynch, M. (2013). Science, truth, and forensic cultures: The exceptional legal status of DNA evidence. Studies in History and Philosophy of Biological and Biomedical Sciences, 44(1), 60-70. https://doi.org/10.1016/j.shpsc. 2012.09.008

Lynch, M., Cole, S., McNally, R., \& Jordan, K. (2008). Truth machine: The contentious history of DNA fingerprinting. Chicago: University of Chicago Press.

Lynch, M., \& Jasanoff, S. (1998). Contested identities: Science, law and forensic practice. Social Studies of Science, 28(5-6), 675-686. https://doi.org/10. $1177 / 030631298028005001$ 
Machado, H., \& Granja, R. (2019). Police epistemic culture and boundary work with judicial authorities and forensic scientists: The case of transnational DNA data exchange in the EU. New Genetics and Society, 38(3), 289-307. https:// doi.org/10.1080/14636778.2019.1609350

Machado, H., \& Prainsack, B. (2012). Tracing technologies: Prisoners' views in the era of CSI. Farnham, UK: Ashgate.

Machado, H., Santos, F., \& Silva, S. (2011). Prisoners' expectations of the national forensic DNA database: Surveillance and reconfiguration of individual rights. Forensic Science International, 210(1-3), 139-143. https://doi.org/10. 1016 /j.forsciint.2011.02.020

McCartney, C. (2006). Forensic identification and criminal justice: Forensic science, justice and risk. Cullompton: Willan Publishing.

Murphy, E. (2007). The new forensics: Criminal justice, false certainty, and the second generation of scientific evidence. California Law Review, 95(3), 721-797.

Nuffield Council on Bioethics. (2007). The forensic use of bioinformation: Ethical issues. London. Retrieved from https://nuffieldbioethics.org/assets/pdfs/ The-forensic-use-of-bioinformation-ethical-issues.pdf

Prainsack, B., \& Kitzberger, M. (2009). DNA behind bars: Other ways of knowing forensic DNA technologies. Social Studies of Science, 39(1), 51-79. https:// doi.org/10.1177/0306312708097289

Saks, M. J., \& Koehler, J. J. (2008). The individualization fallacy in forensic science evidence. Vanderbilt University Law Review, 61(1), 199-219. https:// papers.ssrn.com/sol3/papers.cfm?abstract_id=1432516

Santos, F. (2014). Making sense of the story: The dialogues between the police and forensic laboratories in the construction of DNA evidence. New Genetics and Society, 33(2), 181-203. https://doi.org/10.1080/14636778 .2014 .916186

Schiffer, B., \& Champod, C. (2008). Judicial error and forensic science: Pondering the contribution of DNA evidence. In C. R. Huff \& M. Killias (Eds.), Wrongful conviction. International perspectives on miscarriages of justice (pp. 33-55). Temple University Press.

Schweitzer, N. J., \& Saks, M. J. (2007). The CSI effect: Popular fiction about forensic science affects the public's expectations about real forensic science. Jurimetrics Journal, 47, 357-364.

Shelton, D. E., Kim, Y. S., \& Barak, G. (2006). A study of juror expectations and demands concerning scientific evidence: Does the "CSI Effect" exist? Vanderbilt Journal of Entertainment \& Technology Law, 9(2), 331-368.

Skinner, D. (2013). "The NDNAD has no ability in itself to be discriminatory": Ethnicity and the governance of the UK National DNA Database. Sociology, 47(5), 976-992. https://doi.org/10.1177/0038038513493539

Smith, L. A. (2017). The missing, the martyred and the disappeared: Global networks, technical intensification and the end of human rights genetics. Social 
Studies of Science, 47(3), 398-416. https://doi.org/10.1177/030631 2716678489

Toom, V. (2017). Finding closure, continuing bonds, and codentification after the 9/11 attacks. Medical Anthropology: Cross Cultural Studies in Health and Illness, 37(4), 267-279. https://doi.org/10.1080/01459740.2017.1337118 Toom, V. (2018). Cross-border exchange and comparison of forensic DNA data in the context of the Prïm Decision. Civil liberties, justice and home affairs. Retrieved from http://www.europarl.europa.eu/thinktank/en/document. html?reference=IPOL_STU(2018)604971

Williams, R., \& Johnson, P. (2004a). Circuits of surveillance. Surveillance \& Society, 2(1), 1-14. Retrieved from https://ojs.library.queensu.ca/index.php/ surveillance-and-society/article/view/3324/3286

Williams, R., \& Johnson, P. (2004b). "Wonderment and dread": Representations of DNA in ethical disputes about forensic DNA databases. New Genetics and Society, 23(2), 205-223. https://doi.org/10.1080/1463677042000237035

Williams, R., \& Johnson, P. (2008). Genetic policing: The use of DNA in criminal investigations. Cullompton: Willan Publishing.

Open Access This chapter is licensed under the terms of the Creative Commons Attribution 4.0 International License (http://creativecommons.org/licenses/ by $/ 4.0 /)$, which permits use, sharing, adaptation, distribution and reproduction in any medium or format, as long as you give appropriate credit to the original author(s) and the source, provide a link to the Creative Commons licence and indicate if changes were made.

The images or other third party material in this chapter are included in the chapter's Creative Commons licence, unless indicated otherwise in a credit line to the material. If material is not included in the chapter's Creative Commons licence and your intended use is not permitted by statutory regulation or exceeds the permitted use, you will need to obtain permission directly from the copyright holder.

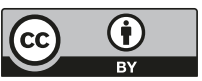




\title{
DNA Databases and Big Data
}

\begin{abstract}
Criminal DNA databases are expanding in different regions of the world to support the activities of the criminal justice system. The use of techniques that combine different sources of digital information for preventing and anticipating the risk of crime (one of the potential uses of so-called Big Data) is increasingly seen as a promising strategy to govern crime. This chapter provides an overview of the development of technological systems orientated towards genetic surveillance of criminalized populations. It also outlines a comprehensive mapping of the main ethical, social and political challenges related to the growing uses of DNA databases and Big Data at a global scale.
\end{abstract}

Keywords DNA databases $\bullet$ Big Data $\bullet$ Ethical challenges $\bullet$ Genetic surveillance

\section{Data Collection in the Information Society}

Forensic genetics has become a significant resource for criminal investigation and evidence-gathering activities for court proceedings in judicial systems around the world (Hindmarsh \& Prainsack, 2010). One of the most prominent aspects of the use of forensic genetics in the criminal justice system is the creation and expansion of centralized national databases that contain genetic profiles that are inserted and stored in function of criteria defined in the legislation of each country (Santos, Machado, \& Silva,

(C) The Author(s) 2020

H. Machado, R. Granja, Forensic Genetics in the Governance of

Crime, https://doi.org/10.1007/978-981-15-2429-5_5 
2013). These databases may contain genetic profiles of convicted persons, suspects, victims, volunteers and other persons of interest, in order to conduct criminal investigations.

A database provides a matrix of genetic profiles based on biological samples collected from a set of individuals. In the context of a pending criminal investigation, traces found in the crime scene or on the victim's body may be analysed and the resulting DNA profiles will be compared with those included in the genetic forensic database, thus making it possible to identify the origin of this vestige, in the event of a positive match.

The process of creating forensic databases with genetic profiles began in the mid-1990s. The first forensic genetic database was set up in England and Wales in 1995, and countries such as the Netherlands (1997), Austria (1997) and Germany (1998) followed suit. It is estimated that there are now 69 countries around the world operating this type of database and that at least 34 countries are starting the process of implementing their own database (Interpol, 2016; Prainsack \& Aronson, 2015). Such databases exist in different regions of the world, especially in Europe and North America: however, recent developments point to growing expansion in Asia, in particular in China, India and South Korea (Forensic Genetics Policy Initiative, 2017).

The creation of databases to support criminal investigation is aligned with the social, economic and political context of the so-called information society, which many authors consider to be a society of maximum surveillance that began to emerge in the mid-1980s (Boersma, Van Brakel, Fonio, \& Wagenaar, 2014; Garland, 2001; Lyon, 1992, 2006; Marx, 2002; Norris \& Armstrong, 1999). The phenomenon of Big Data emerges in the context of technological development and the growing importance of the digital world, which is associated with large-scale collection of citizens' data. It can be defined as a technique that aggregates and analyses a massive amount of data, converting it into algorithms, numerically categorized and identified by employing a calculated index, from which information may be extracted. The technique can be applied in several spheres of social life, including commerce, consumption, health, social security, marketing and immigration. In the context of this book, the authors will pay careful attention to expectations associated to the potential of applying Big Data in the fields of criminal investigation and security (Brayne, 2017; Chan \& Moses, 2015, 2017; Tsianos \& Kuster, 2016). The complexities and challenges arising from the use of forensic DNA databases and Big Data in the context of criminal investigation will be presented and briefly discussed in the different sections of this chapter. 


\section{Ethical Questions Associated with the Use of Forensic DNA Databases}

It is now widely recognized that forensic genetic databases can be beneficial for criminal investigation activities and the production of evidence in the justice system and may eventually contribute to crime prevention and deterrence (Santos et al., 2013; Walsh, Buckleton, Ribaux, Roux, \& Raymond, 2008). However, the use of such databases raises diverse and complex ethical, social and political questions which, from our perspective, must be considered in the context of suitable involvement of various social actors: legislators, judicial operators, forensic experts, politicians (Machado \& Silva, 2015a, 2015b; Wienroth, Morling, \& Williams, 2014). Commentators from different professional fields and scientific disciplines have pointed out the need to consider that the use of forensic genetic databases should be conducted while considering ethical concerns and the need to respect fundamental human rights, such as freedom, autonomy, privacy, presumption of innocence and equality (Amankwaa \& McCartney, 2018; Krimsky \& Simoncelli, 2011; Van Camp \& Dierickx, 2007).

The most controversial ethical issues related to DNA databases for criminal investigation above all concern the criteria related to the selection of the DNA profiles to be included and to the collection, conservation, use and circulation of data. This question is highlighted by the clear trend towards the growing use of such databases. There are other aspects that may raise ethical issues, which will be listed below (Hindmarsh \& Prainsack, 2010; Prainsack \& Aronson, 2015).

The myth of the infallibility of DNA profiling may lead to overlooking possible laboratory errors and other errors and result in the marginalization or even elimination of other types of evidence in court. Identification errors can have profound and irremediable implications, so guaranteeing quality in all technical procedures is also an ethical issue.

There is the possibility of establishing kinship ties through familial searching (see Chap. 7), even though this information might even be unknown to the person who is registered or may constitute a breach of the individual's private life and moral integrity.

Forensic DNA databases reproduce and reinforce social inequalities. Members of specific minorities are more likely to be included in forensic DNA databases and then, consequently, placed under greater surveillance (Chow-White \& Duster, 2011; Skinner, 2012, 2013, 2018). The seminal work of Robin Williams and Paul Johnson (2004) is essential in this respect 
for its analysis of the unique nature of the surveillance based on DNA data and its implications for the construction of suspicion. The authors argue that DNA databases allow for "reconstructive surveillance", forming a circuit surveillance system which holds information that can be applied retrospectively, meaning that people and their actions are not watched, but are inferentially reconstructed using expert practices (Williams \& Johnson, 2004 , pp. 3-6). As the authors note, "DNA databases have a speed, efficiency, automation, and accuracy that are unmatched in the history of policing" (Williams \& Johnson, 2004, p. 8). Moreover, Williams and Johnson explain that DNA databases form "a type of surveillance which is essentially concerned with 'management' of those already deemed criminal $[\ldots]$ delimiting them from the wider population and managing them through assured detection" (Williams \& Johnson, 2004, p. 11).

Finally, it is important to note that there are high costs associated to creating and maintaining a DNA database, and there are no studies that provide consistent evidence of its efficacy, utility and deterrence effect (Toom, Granja, \& Ludwig, 2019). Do the benefits of this technology justify this investment? In other words, can it be argued that these resources will be better applied in crime prevention policies, social reintegration of offenders and/or in ways to reinforce protection for the most vulnerable segments of society?

In 1997, Derick Beyleveld, a specialist in Law and Ethics, proposed the following systematization of what he called the enthusiastic model ("camp enthusiastic") and the pessimistic model ("camp hostile") concerning weighting the risks and benefits associated with the use of forensic DNA databases. This proposal of general models is a mere abstract construction, which selectively accentuates certain aspects of concrete reality (Beyleveld, 1997).

The enthusiastic model of the use of DNA databases within criminal justice appears to be based on a model of criminal justice that focuses on identifying and punishing offenders and deterring crime. It is accepted that, in principle, all individuals may be guilty, and that one of the purposes of the justice system is to find out who actually committed crimes and then punish them. In relation to the normative question of the relationship between the collective good and the individual good, this position is guided by affirmation of the relative superiority of the interests of the community, considering that upholding people's safety and combatting crime are common goods that justify placing constraints on individual rights. From this perspective, emphasis is placed on greater 
effectiveness in identifying guilty persons and valuing a society with more effective structures in controlling individuals and ensuring safety (Beyleveld, 1997).

The pessimistic model emphasizes the potential risks and drawbacks of using DNA databases in the criminal justice system and understands that the primary purpose of the justice system is to uncover the truth and protect the rights of innocent people. It is accepted that, in principle, defendants are presumed to be innocent until proven guilty. There should, therefore, be special attention placed on procedures that protect defendants against the possibility of error and ensure equal access to evidence, both for defence and for prosecution. This position broadens the reflection on the possible harmful consequences for democracy that can be created by a society that chooses people's safety as a supreme good, though the extension of the criteria for inclusion of information in a DNA database may prove to be inadequate and disproportionate to the potential benefits (Beyleveld, 1997).

It should be noted that it is difficult to find empirical evidence of an extreme position, either in legislative, political or expert terms or of what may be the simple assumptions of ordinary citizens (Machado \& Silva, 2015b; Williams \& Johnson, 2004). It is easier to find compromises, which relate to the need to strike a balance between safeguarding people's safety and combatting crime, while upholding citizens' rights, freedoms and guarantees (Amankwaa, 2018; Wilson-Kovacs, 2014; Wilson-Kovacs, Wyatt, \& Hauskeller, 2012). The search and justification of this desirable balance are, however, differentiated. The debate tends to lean towards one side and reflect different views on the following issues: what should be the main objectives and orientations of the criminal justice system, what should be the guiding ethical principles and what are the specific agendas and interests of different social, professional or political groups (Nuffield Council on Bioethics, 2007).

\section{The Panorama of Forensic Genetic Databases in European Countries}

The size of forensic genetic databases and their type of organization and regulation is highly varied. Legislation may state the possible purposes or uses of DNA databases, distinguishing between criminal identification, civil identification and scientific research purposes. It can also establish the 
scope and means of access to the information held in the database; for example, whether all authorities (judicial authorities or police forces) have access or whether access is restricted to certain agents of the justice system. Or whether only information about matches between genetic profiles may be communicated or if other information can also be communicated (e.g., personal data relating to the person identified by means of the genetic profile).

Other issues that are usually determined in national legislation are those related to the criteria for insertion and removal of genetic profiles and biological samples. Different options exist in the legislation of different countries that determine the scope and extent of access to the DNA database based on criteria such as the type of crime committed, the maximum duration of the potential sentence, the individual's characteristics and the likelihood of recurrence. As a result, the law is expected to respond to the following questions: which individuals and under what circumstances shall profiles be inserted into the DNA database? What is the fate of biological samples collected from suspects or convicts? What are the deadlines for retention of DNA profiles and samples?

In general terms, the criteria governing the insertion and removal of profiles and samples constitute the variable that will have the most significant impact on the size of databases of genetic profiles. According to Filipe Santos and colleagues, who carried out a study on legislative trends in DNA databases in Europe, there are countries with expansive legislation and others with restrictive legislation (Santos et al., 2013). According to this typology, the countries with restrictive legislation are Germany, Belgium, Spain, France, the Netherlands, Hungary, Ireland, Italy, Luxembourg, Portugal and Sweden, whereas the countries with expansive legislation are Austria, Denmark, Scotland, Slovakia, Estonia, Finland, Latvia, Lithuania and the UK (England, Wales).

According to the authors, if a specific law has few constraints (e.g., the inclusion of the DNA profile of any individual suspected of any punishable offence) on the insertion of profiles into the DNA database for forensic purposes (whether a suspect or convicted person), the country may be designated as having an expansionist tendency with respect to the development of such databases. By contrast, countries with a restrictive tendency are those whose legislation currently contains various constraints that restrict and limit the uses of DNA databases - for example, the imposition of limits on the types of sentences or crimes eligible for the insertion of profiles. 
Table 5.1 Size of several forensic genetic databases in Europe

\begin{tabular}{lrcl}
\hline Country & Population & $\begin{array}{c}\text { Total no. of individuals } \\
\text { inserted in the database }\end{array}$ & $\begin{array}{l}\text { Proportion of population } \\
\text { in the database }\end{array}$ \\
\hline Germany & $82,000,000$ & 857,000 & $1.0 \%$ \\
Austria & $8,100,000$ & 203,054 & $2.5 \%$ \\
Denmark & $5,500,000$ & 116,433 & $2.1 \%$ \\
France & $66,030,000$ & $3,282,418$ & $5.0 \%$ \\
Netherlands & $17,000,000$ & 237,254 & $1.4 \%$ \\
Scotland & $5,500,000$ & 311,107 & $5.7 \%$ \\
Hungary & $9,982,000$ & 148,384 & $1.5 \%$ \\
England and & $53,700,000$ & $4,733,755$ & $8.8 \%$ \\
Wales & & & \\
Sweden & $9,894,888$ & 153,008 & $1.5 \%$ \\
\hline
\end{tabular}

Source: ENFSI (2016)

It should be noted that the apparent dichotomy between the expansionist and restrictive tendencies refers to the potential specific effects of legislative provisions. These effects are reflected, for example, in the proportion of the national population present in the database of each country. Table 5.1 shows the size of several forensic genetic databases in Europe. It should be pointed out that although it presents a type of "restrictive" legislation, there has been remarkable expansion over recent years, and it now occupies the third largest forensic genetic database in Europe. The database of genetic profiles in England and Wales remains the largest of all, notwithstanding recent legislative changes in the wake of the decision of the European Court of Human Rights (ECHR) following S. \& Marper v. $\mathrm{UK}^{1}$ (McCartney, Williams, \& Wilson, 2010), which ordered the destruction of biological samples and the elimination of DNA profiles of

${ }^{1} S$ \& Marper v. UK refers to a complaint lodged with the European Court of Human Rights by two individuals (S, an 11-year-old child, and Marper) against the UK. Both S. and Marper were detained in unrelated circumstances in 2001, and their fingerprints and DNA samples were collected. No accusations resulted from the arrests, which led them to ask the Chief Constable to eliminate the records. The requests were denied. After appeals against the Chief Constable's decision to the courts and the House of Lords, it was determined that although individuals had not been charged with any crime, and despite the possible breach of privacy, fingerprint retention and DNA profiling was considered to be beneficial to society (McCartney et al., 2010). The ECHR's decision went the other way, and determined that the retention of fingerprints and DNA profiles of suspects who haven't been convicted constitutes a "disproportionate interference" with individuals' rights to privacy and "cannot be taken for granted in a democratic society" (Council of Europe, 2008, par. 125). 
acquitted suspects or persons who haven't been accused of any crime (Amankwaa \& McCartney, 2019).

Despite legislative differences in European DNA databases, the dominant trend towards their generalization and more harmonized sharing of information has been increasingly encouraged, based on the common threat of cross-border crime and terrorism. After the implementation of the Prüm Decisions (EU Council, 2008a, 2008b), in particular the parts related to sharing of information from DNA databases may lead to the need for further legislative harmonization in the various EU countries-a topic that will be further explored in Chap. 6. Given the diversity of the criteria for insertion and removal of DNA profiles and preservation of samples, it is difficult to ensure compliance with the principles of equality, proportionality and presumption of innocence in the context of the transfer of information about DNA profiles between the Member States. For example, the apparent insufficiency of a policy of standardization and monitoring of processes related to cooperation activities, and also the collection, retention, processing, interpretation and legal application of information on DNA profiles, within the framework of the planned measures (Amankwaa, 2019; McCartney, Wilson, \& Williams, 2011; Santos \& Machado, 2017; Toom, 2018).

\section{Big Data in the Criminal Investigation}

The topic of Big Data has gained increasing visibility in the public arena and academic studies. It is generally understood to be a phenomenon which, using digital technology, collects, stores and analyses data from various sources for certain specific purposes. A popularized assumption regarding Big Data is that its essence might be defined by using three "V's": volume, velocity and variety. Other characteristics can also be listed: Big Data refers to data sets with a high level of completeness (e.g., covering entire populations) that contain contextual information that can identify concrete and specific situations (e.g., instead of identifying groups or types of people, it makes it possible to identify specific persons). Also, such data sets are relational (i.e., they make it possible to compare data derived from different sources) and flexible (they can incorporate new data at any moment) (Chan \& Moses, 2015; Kitchin, 2014a, 2014b).

From a sociological perspective it is crucial to address Big Data as a cultural, social and political phenomenon (Boyd \& Crawford, 2012), 
which encompasses the following dimensions, as defined by Janet Chan and Lyria Bennett Moses:

(1) Technology: maximizing computation power and algorithmic accuracy to gather, analyze, link and compare large data sets. (2) Analysis: drawing on large data sets to identify patterns in order to make economic, social, technical and legal claims. (3) Mythology: the widespread belief that large data sets offer a higher form of intelligence and knowledge that can generate insights that were previously impossible, with the aura of truth, objectivity and accuracy. (Chan \& Moses, 2015, p. 24)

The "mythological" aspect associated with Big Data finds similarities in the social imaginaries associated to forensic genetics, and is also liable to generate expectations of producing irrefutable truths in the identification of perpetrators (Lynch, Cole, McNally, \& Jordan, 2008). This type of social expectation concerning Big Data opens the doors to expansion and reinforcement of surveillance practices, which will henceforth take on specific new contours while reproducing "old" practices.

A central aspect of Big Data's implications for criminal investigation concerns the predictive and anticipatory nature of risk. This aspect of Big Data reinforces a trend that is already seen in the creation and expansion of forensic genetic databases, as described in earlier sections of this chapter. Big Data therefore emerges as a reinforcement of the trends towards foreseeing and anticipating risk: through massive quantification and new possibilities for rapid cross-checking of data from sources that until recently have been dispersed, such as the proliferation of automatic alert systems which, on an unprecedented scale, monitor people who have never had any contact with the criminal justice system (Brayne, 2017).

In the framework of criminal investigation, Big Data can, therefore, act as a means of generating intelligence for criminal investigation, making it possible to quantify assessment of risk and classify individuals according to their degree of risk. For example, Big Data techniques can serve to determine the risk that specific individuals will commit a crime or terrorist act (Ball, Di Domenico, \& Nunan, 2016; Lyon, 2014). Quantification of the level of risk presented by certain individuals means that Big Data reinforces the surveillance of social groups and individuals who are more vulnerable to police suspicion, thereby consolidating social mechanisms of stigmatization and reproduction of social inequalities (Brayne, 2017; Kitchin, 2014b; Matzner, 2016; Raley, 2013). 


\section{Concluding Remarks}

In the context of this chapter, DNA databases and Big Data techniques are both seen as processes through which new and effective social control modalities have been configured. Such processes are associated with political and governmental strategies for crime prevention and control, in societies that are increasingly less tolerant of "suspicious" citizens and willing to adopt more intensive regimes of social control, regulation and inspection. The analysis in this chapter is underpinned by the understanding of the concept of surveillance as the streamlined control of information in modern organizations intertwined with capitalist production and consumption systems and with the bureaucratic functioning of the State (Haggerty \& Ericson, 2000; Lyon, 2004, 2014).

\section{REFERENCES}

Amankwaa, A. O. (2018). Forensic DNA retention: Public perspective studies in the United Kingdom and around the world. Science \& Justice. https://doi. org/10.1016/j.scijus.2018.05.002

Amankwaa, A. O. (2019). Trends in forensic DNA database: Transnational exchange of DNA data. Forensic Sciences Research, 1-7. https://doi.org/10.1 $080 / 20961790.2019 .1565651$

Amankwaa, A. O., \& McCartney, C. (2018). The UK National DNA Database: Implementation of the Protection of Freedoms Act 2012. Forensic Science International, 284, 117-128. https://doi.org/10.1016/j.forsciint. 2017.12.041

Amankwaa, A. O., \& McCartney, C. (2019). The effectiveness of the UK national DNA database. Forensic Science International: Synergy, 1, 45-55. https://doi. org/10.1016/J.FSISYN.2019.03.004

Ball, K., Di Domenico, M., \& Nunan, D. (2016). Big Data surveillance and the body-subject. Body \& Society, 22(2), 58-81. https://doi.org/10.1177/1357 $034 \mathrm{Xl} 5624973$

Beyleveld, D. (1997). Ethical issues in the forensic applications of DNA analysis. Forensic Science International, 88(1), 3-15.

Boersma, K., Van Brakel, R., Fonio, C., \& Wagenaar, P. (Eds.). (2014). Histories of state surveillance in Europe and beyond. New York: Routledge.

Boyd, D., \& Crawford, K. (2012). Critical questions for Big Data. Information, Communication \& Society, 15(5), 662-679. https://doi.org/10.1080/13691 18X.2012.678878

Brayne, S. (2017). Big Data surveillance: The case of policing. American Sociological Review, 82(5), 977-1008. https://doi.org/10.1177/ 0003122417725865 
Chan, J., \& Moses, L. B. (2015). Is Big Data challenging criminology? Theoretical Criminology, 20(1), 21-39. https://doi.org/10.1177/1362480615586614

Chan, J., \& Moses, L. B. (2017). Making sense of Big Data for security. British Journal of Criminology, 57(2), 299-319. https://doi.org/10.1093/bjc/ azw059

Chow-White, P., \& Duster, T. (2011). Do health and forensic DNA databases increase racial disparities? PLoS Medicine, 8(10), el001100-el001100. https://doi.org/10.1371/journal.pmed.1001100

Council of Europe. (2008). Case of S. and Marper v. The United Kingdom (Applications nos. 30562/04 and 30566/04). Strasbourg. Retrieved from https://rm.coe.int/168067d216

ENFSI. (2016, June). ENFSI survey on DNA databases in Europe. Retrieved from http://enfsi.eu/wp-content/uploads/2017/01/ENFSI-Survey-on-DNADatabases-in-Europe-June-2016.pdf

EU Council. Council Decision 2008/615/JHA of 23 June 2008 on the stepping up of cross-border cooperation, particularly in combating terrorism and crossborder crime, 2007 Official Journal of the European Union $\$$ (2008a). Official Journal of the European Union.

EU Council. Council Decision 2008/616/JHA of 23 June 2008 on the implementation of Decision 2008/615/JHA on the stepping up of cross-border cooperation, particularly in combating terrorism and cross-border crime, 2008 $\$(2008 b)$. Official Journal of the European Union.

Forensic Genetics Policy Initiative. (2017). Establishing best practice for forensic DNA databases. Retrieved from http://dnapolicyinitiative.org/report/

Garland, D. (2001). The culture of control: Crime and social order in contemporary society. Oxford: Oxford University Press.

Haggerty, K. D., \& Ericson, R. V. (2000). The surveillant assemblage. The British Journal of Sociology, 51(4), 605-622. https://doi.org/10.1080/000713 10020015280

Hindmarsh, R., \& Prainsack, B. (Eds.). (2010). Genetic suspects: Global governance of forensic DNA profiling and databasing. Cambridge: Cambridge University Press.

Interpol. (2016). Global DNA profiling survey results 2016. Retrieved from https:// www.interpol.int/content/download/4875/file/GlobalDNASurvey.pdf

Kitchin, R. (2014a). Big Data, new epistemologies and paradigm shifts. Big Data \& Society, 1(1), 205395171452848. https://doi.org/10.1177/2053951 714528481

Kitchin, R. (2014b). The data revolution: Big Data, open data, data infrastructures and their consequences. London: Sage.

Krimsky, S., \& Simoncelli, T. (2011). Genetic justice: DNA data banks, criminal investigations, and civil liberties. New York: Columbia University Press. 
Lynch, M., Cole, S., McNally, R., \& Jordan, K. (2008). Truth machine: The contentious history of DNA fingerprinting. Chicago: University of Chicago Press.

Lyon, D. (1992). The new surveillance: Electronic technologies and the maximum security society. Crime, Law and Social Change, 18(1-2), 159-175.

Lyon, D. (2004). Globalizing surveillance: Comparative and sociological perspectives. International Sociology, 19(2), 135-149. https://doi.org/10.1177/ 0268580904042897

Lyon, D. (2006). Theorizing surveillance: The panopticon and beyond. Cullopmpton, Devon: Willan Pub.

Lyon, D. (2014). Surveillance, Snowden, and Big Data: Capacities, consequences, critique. Big Data \& Society, 1(2), 1-13. https://doi.org/10.1177/ 2053951714541861

Machado, H., \& Silva, S. (2015a). Public participation in genetic databases: Crossing the boundaries between biobanks and forensic DNA databases through the principle of solidarity. Journal of Medical Ethics, 41(10), 820-824. https://doi.org/10.1136/medethics-2014-102126

Machado, H., \& Silva, S. (2015b). Public perspectives on risks and benefits of forensic DNA databases: An approach to the influence of professional group, education, and age. Bulletin of Science, Technology of Society, 35(1-2), 16-24. https://journals.sagepub.com/doi/full/10.1177/0270467615616297

Marx, G. T. (2002). What's new about the "new surveillance"? Classifying for change and continuity. Surveillance \& Society, 1(1), 9-29. https://link. springer.com/article/10.1007\%2FBF02687074

Matzner, T. (2016). Beyond data as representation: The performativity of Big Data in surveillance. Surveillance \& Society, 14(2), 197-210. https://ojs.library. queensu.ca/index.php/surveillance-and-society/article/view/beyond_data

McCartney, C., Williams, R., \& Wilson, T. (2010). The future of forensic bioinformation - Executive summary. Leeds. Retrieved from https://essl.leeds.ac.uk/ law-research-expertise/dir-record/research-projects/756/the-future-offorensic-bioinformation

McCartney, C., Wilson, T., \& Williams, R. (2011). Transnational exchange of forensic DNA: Viability, legitimacy, and acceptability. European Journal on Criminal Policy and Research, 17(4), 305-322. https://doi.org/10.1007/ s10610-011-9154-y

Norris, C., \& Armstrong, G. (1999). The maximum surveillance society: The rise of CCTV. Oxford and New York: Berg.

Nuffield Council on Bioethics. (2007). The forensic use of bioinformation: Ethical issues. London. Retrieved from http://nuffieldbioethics.org/wp-content/ uploads/The-forensic-use-of-bioinformation-ethical-issues.pdf

Prainsack, B., \& Aronson, J. (2015). Forensic genetic databases: Ethical and social dimensions. International Encyclopedia of the Social of Behavioral Sciences, 9, 339-345. https://doi.org/10.1016/B978-0-08-097086-8.82062-0 
Raley, R. (2013). Dataveillance and countervailance. In L. Gitelman (Ed.), Raw data is an oxymoron (pp. 121-145). Cambridge, MA: MIT Press.

Santos, F., \& Machado, H. (2017). Patterns of exchange of forensic DNA data in the European Union through the Prüm system. Science \& Justice, 57(4), 307313. https://doi.org/10.1016/j.scijus.2017.04.001

Santos, F., Machado, H., \& Silva, S. (2013). Forensic DNA databases in European countries: Is size linked to performance? Life Sciences, Society and Policy, $9(12)$, 1-13. https://doi.org/10.1186/2195-7819-9-12

Skinner, D. (2012). Mobile identities and fixed categories: Forensic DNA and the politics of racialized data. In K. Schramm, D. Skinner, \& R. Rottenburg (Eds.), Identity politics and the new genetics: Re/creating categories of difference and belonging (pp. 53-78). New York and Oxford: Berghahn Books.

Skinner, D. (2013). "The NDNAD has no ability in itself to be discriminatory": Ethnicity and the governance of the UK National DNA Database. Sociology, 47(5), 976-992. https://doi.org/10.1177/0038038513493539

Skinner, D. (2018). Race, racism and identification in the era of technosecurity. Science as Culture, 1-23. https://doi.org/10.1080/09505431.2018.1523887

Toom, V. (2018). Cross-border exchange and comparison of forensic DNA data in the context of the Prüm Decision. Civil Liberties, Justice and Home Affairs. Retrieved from http://www.europarl.europa.eu/thinktank/en/document. html? reference $=$ IPOL_STU $(2018) 604971$

Toom, V., Granja, R., \& Ludwig, A. (2019). The Prüm Decisions as an aspirational regime: Reviewing a decade of cross-border exchange and comparison of forensic DNA data. Forensic Science International: Genetics, 41, 50-57. https:// doi.org/10.1016/j.fsigen.2019.03.023

Tsianos, V. S., \& Kuster, B. (2016). Eurodac in times of bigness: The power of Big Data within the emerging European IT agency. Journal of Borderlands Studies, 31(2), 235-249. https://doi.org/10.1080/08865655.2016.1174606

Van Camp, N., \& Dierickx, K. (2007). National forensic databases: Social-ethical challenges \& current practices in the EU. Leuven: European Ethical-Legal Papers no. 9. Retrieved from http://www.academia.edu/attachments/ 6227872/download_file

Walsh, S. J., Buckleton, J. S., Ribaux, O., Roux, C., \& Raymond, T. (2008). Comparing the growth and effectiveness of forensic DNA databases. Forensic Science International: Genetics Supplement Series I, 1(1), 667-668. https:// doi.org/10.1016/j.fsigss.2007.11.011

Wienroth, M., Morling, N., \& Williams, R. (2014). Technological innovations in forensic genetics: Social, legal and ethical aspects. Recent Advances in DNA and Gene Sequences, 8(2), 98-103. Retrieved from http://www.eurekaselect. com/129834/article\%5Cnpapers3://publication/uuid/7539311B-9CDA4A2B-A9AF-4F93CE7142EE 
Williams, R., \& Johnson, P. (2004). Circuits of surveillance. Surveillance \& Society, 2(1), 1-14. https://ojs.library.queensu.ca/index.php/surveillanceand-society/article/view/3324

Wilson-Kovacs, D. (2014). "Clearly necessary", "wonderful" and "engrossing"? Mass observation correspondents discuss forensic technologies. Sociological Research Online, 19(3), 1-16. https://doi.org/10.5153/sro.3375

Wilson-Kovacs, D., Wyatt, D., \& Hauskeller, C. (2012). "A Faustian bargain?” Public voices on forensic DNA technologies and the National DNA Database. New Genetics and Society, 31(3), 285-298. Retrieved from http://www.tandfonline.com/doi/abs/10.1080/14636778.2012.687085

Open Access This chapter is licensed under the terms of the Creative Commons Attribution 4.0 International License (http://creativecommons.org/licenses/ by $/ 4.0 /$ ), which permits use, sharing, adaptation, distribution and reproduction in any medium or format, as long as you give appropriate credit to the original author(s) and the source, provide a link to the Creative Commons licence and indicate if changes were made.

The images or other third party material in this chapter are included in the chapter's Creative Commons licence, unless indicated otherwise in a credit line to the material. If material is not included in the chapter's Creative Commons licence and your intended use is not permitted by statutory regulation or exceeds the permitted use, you will need to obtain permission directly from the copyright holder.

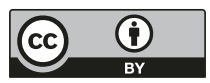




\title{
Forensic Genetics and Governance of Transnational Criminality
}

\begin{abstract}
Contemporary societies are increasingly facilitating movement while simultaneously creating forms of restricting and monitoring the mobility of persons deemed problematic. This chapter focuses on the growing relevance of genetic technologies in this domain by discussing the several forms whereby genetics has been used to prevent, manage and survey transnational criminality. In order to shed light on the complexities associated with such a phenomenon, we provide the reader with an indepth explanation of an empirical example: a pan-European network, called the Prüm system, created to exchange the data stored in the national DNA databases of different European Union (EU) countries in order to combat terrorism and cross-border criminality.
\end{abstract}

Keywords International mobility $\bullet$ Transnational criminality $\bullet$ Exchange of DNA data $\bullet$ Prüm system

\section{The Control of Irregular Mobility}

The celebration and facilitation of the movement of people, goods and capital within the European Union (EU) coexists with attempts to monitor, restrict or inhibit the mobility of individuals deemed problematic (Aas, 2013; Bigo, 2005; Pickering \& Weber, 2006). Although Europe's internal borders have been to a certain extent abolished, as pointed out by Dennis Broeders and Huub Dijstelbloem, "mobility is not for everyone:

(C) The Author(s) 2020 
there is a politics of mobility in which the differential distribution of mobility produces some of the starkest differences today" (Broeders \& Dijstelbloem, 2016, p. 245). As a result, surveillance systems are increasingly being deployed to work as instruments of social sorting (Lyon, 2007), segregating between "legitimate" and "illegitimate" mobilities (Amoore, 2006). Respectively, one kind of mobility is associated with high economic, cultural and social capital, regarding individuals moving due to leisure and/or business; while another kind of mobility is associated with irregular immigration and/or criminal practices (Aas, 2011). It is thereby clear that tracing mobility is no longer solely focused on territorial borders. The management of borders has shifted and expanded to a focus on internationally mobile populations that are considered as suspect communities (Aas, 2011; Ajana, 2013; Bosworth \& Guild, 2008; Broeders, 2007; Skinner, 2018; Tutton, Hauskeller, \& Sturdy, 2014). Such suspect communities are defined by the interlinking of nationality, race and (lack thereof of) social, cultural and economic power.

Transnational criminality tends to be approached as one of the most significant challenges posed by international mobility. As a result, at least in terms of public discourse, the prevention and investigation of crossborder crime have been the main driving force and justification for the proliferation of surveillance systems (Aas, 2011, p. 337). Nowadays, societies have been witnessing a swift development in the expansion of networks of surveillance systems and networked databases aimed at visualizing, registering, mapping, monitoring and profiling mobile populations defined in terms of risk (Broeders \& Dijstelbloem, 2016). Within such context, biometric technologies have been increasingly deployed as the prime form to control and manage international mobility (Aas, 2011). Biometric technologies create an inseparability between corporal and digital elements in contemporary governance projects (M'charek, Schramm, \& Skinner, 2014).

This chapter focuses on a EU system which clearly outlines the role of forensic genetics in the governance of crime: a pan-European network, called the Prüm system, created to exchange the data stored in the national databases of different EU countries in order to combat terrorism and cross-border criminality. Several policies aimed at crime control and migration directly or indirectly highlight and discriminate against minorities and populations or individuals originating from specific countries. Contrary to such a scenario, the Prüm system directly targets already criminalized populations, since it networks different forensic DNA databases. 


\section{Background and Rationale of the Prüm Decisions}

In the aftermath of Schengen, ${ }^{1}$ which abolished border controls in a number of European countries, several EU Member States became increasingly concerned about transnational movements of people deemed risky and, consequently, about the growth of transnational crime (Broeders, 2007; Guild \& Geyer, 2008; Hufnagel \& McCartney, 2017). Although the informal exchange of DNA data has often taken place on an ad hoc basis (Hufnagel \& McCartney, 2015; McCartney, Wilson, \& Williams, 2011), it was no longer deemed as sufficient and, consequently, voices began to be heard calling for a closer cooperation among police forces (Luif, 2007).

Attempting to respond to such perceived need to expand the transnational surveillance network and foster closer police cooperation, on May 2005, in the small German town of Prüm, the government representatives from Austria, Belgium, France, Luxembourg, Germany, the Netherlands and Spain signed a treaty that would become known as the Prüm Convention, ${ }^{2}$ which set provisions for exchanging data regarding DNA, fingerprints and motor vehicle information. The preamble of the Convention stated that, in the context of the free movement of persons, the EU Member States had to

[p]lay a pioneering role in establishing the highest possible standard of cooperation, especially by means of exchange of information, particularly in combating terrorism, cross-border crime and illegal migration, while leaving participation in such cooperation open to all other Member States in the European Union. (EU Council, 2005, p. 3)

The background leading to the Prüm Convention was an initiative by Otto Schily, the former Interior Minister of Germany who, in 2003, proposed a closer cooperation in justice and internal affairs with France, Belgium and Luxembourg in a context where a Police Centre was opened in Luxembourg by the four countries. According to Paul Luif (2007), this

\footnotetext{
${ }^{1}$ The Schengen acquis, in 1995, pertains to the abolition of border controls of a number of European countries. Subsequently, the Treaty of Amsterdam, in 1997, has adopted the Schengen agreement into EU law.

${ }^{2}$ In this chapter the authors use the term "Prüm Convention" to refer to the 2005 Convention involving seven countries, the term "Prüm Decision" to refer to the Council Decision that established the mandatory nature of transnational data exchange for all EU Member States and the term "Prüm system" to refer to the actual network of European Union countries exchanging DNA data.
} 
initiative, which aimed to develop a closer cooperation between the police forces of Germany and its neighbours, was deemed necessary because of "transnational crime, which had increased after removing the Iron curtain at the end of the Cold War and which had been made easier by the ceasing of border controls between the participants of the Schengen area" (Luif, 2007: 6; see also Bigo, 2004, 2008: 94; Bigo \& Guild, 2005; Kuus, 2004; M'charek et al., 2014: 16).

In 2008, some of the Prüm Convention provisions were subsumed into the police and judicial cooperation provisions in European Union law by a Council Decision, commonly referred to as the Prüm Decisions (EU Council, 2008a, 2008b). These Prüm Decisions made it mandatory for all EU Member States to join the pan-European network for the exchange of fingerprints, DNA profiles and motor vehicle information. It was decided that data should remain the property of the Member State where it was collected, eliminating the need for a centralized database. Therefore, this meant that all EU Member States that had yet to establish databases for DNA profiles, fingerprints and vehicle data information were obliged to do so, in order to allow access to them to the relevant EU authorities. August 2011 was the deadline established for all EU countries to comply with the Prüm Decisions. However, most countries were unable to comply with such a deadline due to several reasons (McCartney et al., 2011; Prainsack \& Toom, 2013): (1) difficulties faced in the mobilization of political majorities to adapt national laws to Prüm provisions; (2) conflicts between stakeholders over who should take responsibilities for Prüm; (3) human and financial resources (Prainsack \& Toom, 2013; Töpfer, 2011). Moreover, Italy, Greece, Ireland and Malta faced additional constraints as they did not have a DNA database or dedicated legislation when the Prüm Decisions were adopted (Toom, Granja, \& Ludwig, 2019).

Currently, the latest report on the progress of the implementation of Prüm on DNA data, dating from September 2019, indicates that there are 25 EU Member States in operational conditions (EU Council, 2019). The non-operational countries are Greece, Ireland and Italy. Being operational within Prüm's transnational exchange of DNA data does not, however, immediately imply that all operational countries are connected. Available data also shows that the level of connection is very different: while the Netherlands and Austria are connected to 23 countries, Bulgaria is exchanging DNA data with 9 countries and the UK with 1 country (EU Council, 2019). 


\section{PrÜM Modus OPERANDI}

Transnational DNA data exchange within the Prüm system works as follows: when a search is made in a national database for a DNA sample retrieved from a crime scene and no match is found, the Council Decision permits the data to be transmitted and searched in the national databases of other Member States (the so-called Step 1 of the Prüm system). A notification is then sent to the original Member State notifying it of a hit or the lack thereof. If a hit is identified, further requests for information are processed through the existing police or judicial channels (the so-called Step 2 of the Prüm system, which is governed by national law).

The EU regulation of the Prüm system stipulates that, for the purposes of supplying data, each Member State shall designate a National Contact Point (NCP), and the powers of the NCPs shall be governed by the applicable national law (Decision 2008/615/JHA). Different countries have attributed the custody of the national DNA databases to different entities, ranging from judicial authorities to police forces. In the great majority of countries involved in the Prüm system, the Ministry of the Interior (or Ministry of Internal Affairs or Ministry of Home Affairs) - a government ministry typically responsible for policing, emergency management, national security and immigration matters - has custody over the National Criminal DNA Database. The exceptions to this scenario are Belgium, the Netherlands, Portugal and Sweden, in which the Ministry of Justice has custody over the National DNA Database. The Ministry of Justice typically has specific duties associated with the organization of the justice system, overseeing public prosecutors and maintaining the legal system and public order. As a result of such a diversified context, the roles and responsibilities of Prüm NCPs may vary among countries, according to different organizational structures and national legislation.

The forensic practitioners acting as NCPs are central actors in the Prüm regime: they conduct the daily activities that enable transnational exchange and hold a crucial position in decision-making processes. In particular, the persons acting as NCPs must organize and implement the necessary procedures and connections to perform automated exchanges with other databases (both receiving and sending information), perform tests with partners in other countries as well as manage and report DNA matches. The NCPs in charge of complying with the technical standards for the exchange of DNA data information among Member States on a hit/nohit basis are officially called Step 1 NCPs. Typically, these NCPs are 
forensic experts working in forensic genetics laboratories. The NCPs in charge of the requests for additional information through mutual assistance procedures are called Step 2 NCPs and are usually professionals with relevant experience in police and judicial cooperation in transnational criminal investigations. Therefore, the Prüm regime brings together a wide range of professionals and a shifting set of relationships with data, technological infrastructures, operational procedures and criminal justice systems that support the circulation of information (M'charek, Hagendijk, \& de Vries, 2013).

\section{The Prüm Challenges}

The development of the Prüm system has received academic attention that might be summarized along two distinct lines of enquiry: on the one hand, a branch of literature that focuses on Prüm's societal, political and ethical challenges; on the other hand, a group of studies that aim to map the geographical patterns of cross-border crime and DNA data flows among the different EU Member States.

Within this first group of literature, it is clear that the ethical implications of the transnational exchange of forensic DNA data under the Prüm regime are paramount. The current academic debate highlights the ethical challenges related to data protection, the excessive surveillance of citizens and potential threats to civil rights such as privacy, liberty and the presumption of innocence (McCartney, 2010; McCartney et al., 2011; Nuffield Council on Bioethics, 2007). Additionally, several authors observed a democratic deficit when the Prüm Convention was transposed into EU acquis (Balzacq, 2005; Balzacq, Bigo, Carrera, \& Guild, 2006; Bellanova, 2017; Bigo, 2008). Such issues are compounded by the lack of systems to ensure transparency, accountability and trust, as well as ethical oversight of the transnational flow of law enforcement information (Hufnagel \& McCartney, 2015; McCartney, 2013, 2014a, 2014b; McCartney et al., 2011; Prainsack \& Toom, 2010, 2013). Victor Toom and his colleagues, when reviewing a decade of cross-border exchange and comparison of forensic DNA data, outline how their concerns over accountability and transparency posed at the time of the Prüm Decisions (EU Council, 2008a, 2008b) continue to be problematic, as quantitative and publicly available information that would make it possible to access DNA data exchange and comparison in the Prüm regime is limited, disjointed and largely unavailable (Toom, 2018; Toom et al., 2019). 
Another crucial topic of debate within regards the enormous disparities in national legislation across EU Member States. As previously noted in Chap. 5 , in the EU, there is considerable variation among national forensic DNA databases regarding the criteria for including profiles and the periods of time and conditions for their retention and/or deletion (Cho \& Sankar, 2004; Machado \& Silva, 2016; Santos, Machado, \& Silva, 2013; Van Camp \& Dierickx, 2007). Thereby, such a scenario draws attention to the inherent heterogeneities of the Prüm regime, by binding together diverse regulations regarding the collection and retention of forensic bioinformation (Prainsack \& Toom, 2013).

Barbara Prainsack and Victor Toom (2010) explored the situated dis/ empowerment of the Prüm system on the basis of three dimensions: data protection, new investigative epistemology and increasing investment on DNA technologies. In terms of data protection, the authors show that while Prüm might render a wide group of people into objects of surveillance, by working in a two-step approach, it might also reduce the amount of information that travels across borders. Such a decrease will, in principle, occur because personal data is only sent after a match has been confirmed, thus leading to a more targeted exchange. Prainsack and Toom (2010) also outline the forms whereby Prüm co-constructs a new investigative epistemology. By constituting DNA evidence in criminal investigations as central, a new configuration emerges in ways that shift power away from criminal investigators and towards forensic geneticists. Finally, the authors also explore how Prüm might, indeed, contribute to solving crimes in the EU (thus empowering citizens and victims) yet it might also divert attention and resources from other types of crime not directly involving biological evidence, such as human trafficking, fiscal crimes and child abuse (Prainsack \& Toom, 2010).

Some of these preliminary analyses have inspired recent empirically based studies on Prüm. One of such studies explores what "ethics" means to forensic practitioners actively involved in transnational DNA data exchanges under the Prüm system (Machado \& Granja, 2018). Based on interviews with Prüm NCPs, the authors demonstrate that such professionals face a wide variety of ethically significant issues. Participants highlighted that ethics are related to good scientific and laboratory practices, mentioned problems when receiving contaminated samples in the laboratory or reporting false positives to other countries, referred to data protection procedures and outlined efforts to address social accountability by producing reports for assessment by external authorities and/or use by 
the general public. Moreover, the authors found that NCPs created "ethical boundaries" between science/ethics, science/criminal justice systems and good/bad science that aimed to address and manage ethical controversies.

In another publication, Helena Machado and Rafaela Granja addressed the topic of how forensic DNA evidence is given meaning within the various ways of constructing a police epistemic culture within Prüm (Machado \& Granja, 2019a). Based on interviews with NCPs involved in international police cooperation, the authors show how the construction of a particular police epistemic culture is related to dynamics linked to the boundary work that creates, advocates and reinforces distinctions regarding other professionals also involved in transnational cooperation, such as the judicial authorities and forensic scientists. On the one hand, the judicial authorities are seen as a professional group that works mainly through formal procedures on a national or local level, while lacking the experience of international cooperation traditions. On the other hand, police professionals enact boundary work in relation to forensic scientists by outlining how the value of a DNA hit does not reside in the hit by itself but on the police work which can turn DNA data into DNA evidence. Hence, the Prüm system involves the interaction of various epistemic cultures and professional practices, entailing both cooperation and coordination, in addition to enacting the differences and divisions between the different social actors in the criminal justice system (Machado \& Granja, 2019a).

One other study by Helena Machado, Rafaela Granja and Nina Amelung analysed the fluid and flexible forms of constructing suspicion which take shape in transnational governance of crime through forensic DNA databases (Machado, Granja, \& Amelung, 2020). The authors demonstrate that, within the Prüm system, suspicion is constructed through forms of deterritorializing and reterritorializing assumptions about criminality linked to the movements of suspect communities across the EU. The deterritorialization of suspicion is configured in two ways. Firstly, it amplifies imaginaries of Europeanization that are linked to the increase in transnational collaboration in the area of crime control. Considering that the "free" mobility of citizens within the EU facilitates criminal activity across borders, NCPs conceive the emergence of the Prüm system as a logical outcome. The transnational exchange of DNA data is therefore seen as an opportunity to regain "control" over the coexisting mobility of noncriminal and criminal populations. Secondly, the deterritorialization of suspicion also involves incorporating depersonalization, neutrality and 
procedural objectivity into the operations of the automated and permanent DNA data exchange. Juxtaposed to that, the reterritorializing of suspicion operates through the continuous (re)creation of assertions concerning criminality and specific populations from certain East European countries. In this sense, the transnational exchange of DNA data in EU demonstrates how "new" forms of suspicion relate to the reinforcement of "old" criminal categories (Machado et al., 2020).

One last study conducted by Machado and Granja regards how NCPs perceive the risks and benefits of transnational exchange of forensic DNA data. The authors show that the perceived benefits relate to the intensification of tools for combating transnational criminality, development of standardization and harmonization of forensic DNA testing procedures and reinforcement of professional cooperation. The perceived risks are associated to the possibility that individuals may be prosecuted on the basis of false positives, the lack of available data to measure the effectiveness of the Prüm system and the different modus operandi of police forces and judicial authorities (Machado \& Granja, 2019b).

The second group of studies on the Prüm system have been assessing the geographical patterns of cross-border crimes solved by the exchange of DNA data among the different EU Member States (Bernasco, Lammers, \& Van der Beek, 2016; Taverne \& Broeders, 2015, 2016). One study suggested a territorial divide between Western and Central European countries and Eastern European countries. On the basis of an analysis of the official statistical data et of the Prüm system, this research revealed a trend amongst Western and Central European countries to accumulate the majority of DNA profiles of individuals originating from Eastern European countries (Santos \& Machado, 2017). In other words, the study showed how the geographical patterns of DNA flows between the EU Member States involved in the Prüm system appeared to confirm previous research about the patterns of criminal mobility affecting central European countries, which is mostly associated with volume crime usually involving individuals originating from Eastern Europe (Bernasco et al., 2016; Siegel, 2014; Van Daele, 2008).

\section{Concluding Remarks}

Taking into consideration the increasing shifts in several social life domains when collecting and processing massive amounts of data, this chapter articulates how, within contemporary projects that aim to know and 
govern mobile bodies (Aas, 2011; Broeders, 2007), the governance of crime takes place by managing several decisions related to the production, circulation and use of data. The transnational exchange of DNA data via the Prüm system represents a technological infrastructure designed to control transnational mobile populations through a dispersed network featuring an enhanced level of detection.

In addition to fostering a closer collaboration among police forces in the EU, the Prüm system also emerged as an additional driver of the panEuropean integration project by attempting to overcome cultural, political and socioeconomic disparities. It did so through a combination of technological standardization measures among countries and an ongoing emphasis on a prevalent discourse focusing on security and risk prevention (Prainsack \& Toom, 2013). Nevertheless, such a goal of overcoming disparities is paired with the consolidation of a system of wider social sorting that highlights several geopolitical tensions. In other words, since national DNA databases tend to reflect policing practices that usually target minorities, such as foreigners and/or ethnic minorities (Chow-White \& Duster, 2011; Duster, 2006; Skinner, 2013, 2018), by enabling the transnational exchange of data, the Prüm system has the power to reassert and extend the discriminatory power of DNA databases. The transnational exchange of DNA data in the EU thereby enables the (re)making of the connections between criminality and suspicious movements of data and of particular populations leaving specific national territories (Machado et al., 2020).

\section{REFERENCES}

Aas, K. F. (2011). "Crimmigrant" bodies and bona fide travelers: Surveillance, citizenship and global governance. Theoretical Criminology, 15(3), 331-346. https://doi.org/10.1177/1362480610396643

Aas, K. F. (2013). Globalization and crime. Vol. I-III. London: Sage.

Ajana, B. (2013). Governing through biometrics: The biopolitics of identity. London: Palgrave Macmillan.

Amoore, L. (2006). Biometric borders: Governing mobilities in the war on terror. Political Geography, 25(3), 336-351.

Balzacq, T. (2005). From a Prüm of 7 to a Prïm of 8 +: What are the implications? (No. IP/C/LIBE/FWC/2005-22). Policy Department C Citizens Rights and Constitutional Affairs. Brussels.

Balzacq, T., Bigo, D., Carrera, S., \& Guild, E. (2006). Security and the two-level game: The treaty of Prïm, the EU and the management of threats (No. 234). Retrieved from http://aei.pitt.edu/6678/ 
Bellanova, R. (2017). Digital, politics, and algorithms: Governing digital data through the lens of data protection. European Journal of Social Theory, 20(3), 329-347. https://doi.org/10.1177/1368431016679167

Bernasco, W., Lammers, M., \& Van der Beek, K. (2016). Cross-border crime patterns unveiled by exchange of DNA profiles in the European Union. Security Journal, 29(4), 640-660. https://doi.org/10.1057/sj.2015.27

Bigo, D. (2004). Criminalisation of 'migrants': The side effect of will to control the frontiers and sovereign illusion. In B. Bogusz, R. Cholewinski, A. Cygan \& E. Szyszczak (Eds.), Irregular migration and human rights: Theoretical, European and international perspectives (pp. 61-92). Martinus Nijhoff Publishers.

Bigo, D. (2005). Frontier controls in the European Union: Who is in control? In E. Guild (Ed.), Controlling frontiers: Free movement into and within Europe (1sted.,pp.49-99). Routledge.https://doi.org/10.4324/9781315259321-2

Bigo, D. (2008). EU police cooperation: National sovereignty framed by European security? In E. Guild \& F. Geyer (Eds.), Security versus justice? Police and judicial cooperation in the European Union (pp. 91-108). Aldershot: Ashgate.

Bigo, D., \& Guild, E. (2005). Policing in the name of freedom. In D. Bigo \& E. Guild (Eds.), Controlling frontiers: Free movement into and within Europe (pp. 1-13). Aldershot, Burlington: Ashgate.

Bosworth, M., \& Guild, M. (2008). Governing through migration control: Security and citizenship in Britain. British Journal of Criminology, 48(6), 703719. https://doi.org/10.1093/bjc/azn059

Broeders, D. (2007). The new digital borders of Europe: EU databases and the surveillance of irregular migrants. International Sociology, 22(1), 71-92. https://doi.org/10.1177/0268580907070126

Broeders, D., \& Dijstelbloem, H. (2016). The datafication of mobility and migration management: The mediating state. In I. Van der Ploeg \& J. Pridmore (Eds.), Digitizing identities: Doing identity in a networked world (pp. 242260). London: Routledge. https://doi.org/10.4324/9781315756400

Cho, M., \& Sankar, P. (2004). Forensic genetics and ethical, legal and social implications beyond the clinic. Nature Genetics, 36(11 Suppl), S8-S12. https://doi. org/10.1038/ngl594

Chow-White, P., \& Duster, T. (2011). Do health and forensic DNA databases increase racial disparities? PLoS Medicine, 8(10), el001100. https://doi. org/10.1371/journal.pmed.1001100

Council of the European Union. (2019). Implementation of the provisions on information exchange of the "Prïm Decisions". Brussels.

Duster, T. (2006). Explaining differential trust of DNA forensic technology: Grounded assessment or inexplicable paranoia? Journal of Law, Medicine \& Ethics, 34(2), 293-300.

EU Council. (2005). Prüm convention (Vol. 2005). Brussels, 7 July.

EU Council. Council Decision 2008/615/JHA of 23 June 2008 on the stepping up of cross-border cooperation, particularly in combating terrorism and cross- 
border crime, 2007 Official Journal of the European Union $\$$ (2008a). Official Journal of the European Union.

EU Council. Council Decision 2008/616/JHA of 23 June 2008 on the implementation of Decision 2008/615/JHA on the stepping up of cross-border cooperation, particularly in combating terrorism and cross-border crime, 2008 $\$(2008$ b). Official Journal of the European Union.

Guild, E., \& Geyer, F. (2008). Security versus Justice? Police and judicial cooperation in the European Union. Farnham, UK: Ashgate.

Hufnagel, S., \& McCartney, C. (2015). Police cooperation against transnational criminals. In N. Boister \& R. J. Currie (Eds.), Routledge handbook of transnational criminal law (pp. 107-120). Oxon and New York: Routledge.

Hufnagel, S., \& McCartney, C. (Eds.). (2017). Trust in international police and justice cooperation. Oxford: Hart Publishing.

Kuus, M. (2004). Europe's eastern expansion and the reinscription of otherness in East-Central Europe. Progress in Human Geography, 28, 472-489. https:// journals.sagepub.com/doi/10.1191/0309132504ph498oa

Luif, P. (2007). The treaty of Prüm: A replay of Schengen? In European Union Studies Association, Tenth biennial international conference. Montreal, Canada. Retrieved from http://aei.pitt.edu/id/eprint/7953

Lyon, D. (2007). Surveillance studies: An overview. Cambridge: Polity Press.

M'charek, A., Hagendijk, R., \& de Vries, W. (2013). Equal before the law: On the machinery of sameness in forensic DNA practice. Science, Technology, \& Human Values, 38(4), 542-565. https://doi.org/10.1177/0162243912453623

M'charek, A., Schramm, K., \& Skinner, D. (2014). Topologies of race: Doing territory, population and identity in Europe. Science, Technology, \& Human Values, 39(4), 468-487. https://doi.org/10.1177/0162243913509493

Machado, H., \& Granja, R. (2018). Ethics in transnational forensic DNA data exchange in the EU: Constructing boundaries and managing controversies. Science as Culture, 27(2), 242-264. https://doi.org/10.1080/09505431. 2018.1425385

Machado, H., \& Granja, R. (2019a). Police epistemic culture and boundary work with judicial authorities and forensic scientists: The case of transnational DNA data exchange in the EU. New Genetics and Society, 38(3), 289-307.

Machado, H., \& Granja, R. (2019b). Risks and benefits of transnational exchange of forensic DNA data in the EU: The views of professionals operating the Prüm system. Journal of Forensic and Legal Medicine, 68, 101872.

Machado, H., Granja, R., \& Amelung, N. (2020). Constructing suspicion through forensic DNA databases in the EU. The views of the Prüm professionals. The British Journal of Criminology, 60(1), 141-156. https://doi.org/10.1093/ bjc/azz057

Machado, H., \& Silva, S. (2016). Voluntary participation in forensic DNA databases: Altruism, resistance, and stigma. Science, Technology, \& Human Values, 41(2), 322-343. https://doi.org/10.1177/0162243915604723 
McCartney, C. (2010). Trans-national exchange of forensic (bio)information. In G. Bruinsma \& D. Weisburd (Eds.), Emerging issues in international forensic bioinformation exchange (pp. 1-27). University of Leeds, London, UK: Springer.

McCartney, C. (2013). Opting in and opting out: Doing the hokey cokey with EU policing and judicial cooperation. The Journal of Criminal Law, 77, 543-561. https://doi.org/10.1350/jcla.2013.77.6.879

McCartney, C. (2014a). Forensic data exchange: Ensuring integrity. Australian Journal of Forensic Sciences, 47(1), 36-48. https://doi.org/10.1080/004506 18.2014 .906654

McCartney, C. (2014b). Transnational exchange of forensic evidence. In G. Bruinsma \& D. Weisburd (Eds.), Encyclopedia of criminology and criminal justice (pp. 5302-5313). New York: Springer.

McCartney, C., Wilson, T., \& Williams, R. (2011). Transnational exchange of forensic DNA: Viability, legitimacy, and acceptability. European Journal on Criminal Policy and Research, 17(4), 305-322. https://doi.org/10.1007/ s10610-011-9154-y

Nuffield Council on Bioethics. (2007). The forensic use of bioinformation: Ethical issues. London. Retrieved from http://nuffieldbioethics.org/wp-content/ uploads/The-forensic-use-of-bioinformation-ethical-issues.pdf

Pickering, S., \& Weber, L. (2006). Borders, mobility and technologies of control. In S. Pickering \& L. Weber (Eds.), Borders, mobility and technologies of control (1st ed., pp. 1-19). Dordrecht: Springer Netherlands. https://doi. org/10.1007/1-4020-4899-8_1

Prainsack, B., \& Toom, V. (2010). The Prüm regime. Situated dis/empowerment in transnational DNA profile exchange. British Journal of Criminology, 50(6), 1117-1135. https://doi.org/10.1093/bjc/azq055

Prainsack, B., \& Toom, V. (2013). Performing the Union: The Prüm Decision and the European dream. Studies in History and Philosophy of Biological and Biomedical Sciences, 44(1), 71-79. https://doi.org/10.1016/j.shpsc.2012. 09.009

Santos, F., \& Machado, H. (2017). Patterns of exchange of forensic DNA data in the European Union through the Prüm system. Science \& Justice, 57(4), 307313. https://doi.org/10.1016/j.scijus.2017.04.001

Santos, F., Machado, H., \& Silva, S. (2013). Forensic DNA databases in European countries: Is size linked to performance? Life Sciences, Society and Policy, $9(12)$, 1-13. https://doi.org/10.1186/2195-7819-9-12

Siegel, D. (2014). Lithuanian itinerant gangs in the Netherlands. Kriminologijos Studijos, 2, 5-40. Retrieved from https://pdfs.semanticscholar.org/3f8e/ c9ba48b92eb423602a3852656122eb6d38ae.pdf

Skinner, D. (2013). "The NDNAD has no ability in itself to be discriminatory": Ethnicity and the governance of the UK National DNA Database. Sociology, 47(5), 976-992. https://doi.org/10.1177/0038038513493539

Skinner, D. (2018). Race, racism and identification in the era of technosecurity. Science as Culture, 1-23. https://doi.org/10.1080/09505431.2018.1523887 
Taverne, M., \& Broeders, A. P. A. (2015). The light's at the end of the funnel! Evaluating the effectiveness of the transnational exchange of DNA profiles between the Netherlands and other Prüm countries. Zutphen: Paris Legal Publishers.

Taverne, M., \& Broeders, A. P. A. (2016). Cross-border patterns in DNA matches between the Netherlands and Belgium. Science \& Justice, 57(1), 28-34. https://doi.org/10.1016/j.scijus.2016.08.008

Toom, V. (2018). Cross-border exchange and comparison of forensic DNA data in the context of the Prüm Decision. Civil Liberties, Justice and Home Affairs. Retrieved from http://www.europarl.europa.eu/thinktank/en/document. html?reference=IPOL_STU(2018)604971

Toom, V., Granja, R., \& Ludwig, A. (2019). The Prüm Decisions as an aspirational regime: Reviewing a decade of cross-border exchange and comparison of forensic DNA data. Forensic Science International: Genetics, 41, 50-57. https:// doi.org/10.1016/j.fsigen.2019.03.023

Töpfer, E. (2011). 'Network with errors': Europe's emerging web of DNA databases. State Watch Analysis, 21, 1-5.

Tutton, R., Hauskeller, C., \& Sturdy, S. (2014). Suspect technologies: Forensic testing of asylum seekers at the UK border. Ethnic and Racial Studies, 37(5), 738-752. https://doi.org/10.1080/01419870.2013.870667

Van Camp, N., \& Dierickx, K. (2007). National forensic databases: Social-ethical challenges \& current practices in the EU. Leuven: European Ethical-Legal Papers $\mathrm{n}^{\circ} 9$. Retrieved from http://www.academia.edu/attachments/ $6227872 /$ download_file

Van Daele, S. (2008). Organised property crimes in Belgium: The case of the 'itinerant crime groups'. Global Crime, 9, 241-247. Retrieved from https:// www.tandfonline.com/doi/abs/10.1080/17440570802254346?journa lCode $=$ fglc 20

Open Access This chapter is licensed under the terms of the Creative Commons Attribution 4.0 International License (http://creativecommons.org/licenses/ by $/ 4.0 /)$, which permits use, sharing, adaptation, distribution and reproduction in any medium or format, as long as you give appropriate credit to the original author(s) and the source, provide a link to the Creative Commons licence and indicate if changes were made.

The images or other third party material in this chapter are included in the chapter's Creative Commons licence, unless indicated otherwise in a credit line to the material. If material is not included in the chapter's Creative Commons licence and your intended use is not permitted by statutory regulation or exceeds the permitted use, you will need to obtain permission directly from the copyright holder.

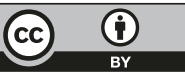




\title{
Emerging DNA Technologies and Stigmatization
}

\begin{abstract}
Despite their consolidated role in providing evidence for criminal justice, DNA technologies have been subjected to continuous investment that has given rise to the emergence of new DNA technologies. This chapter will focus on such innovations, explaining how forensic genetics is increasingly expanding its role in the criminal justice system. Recent technologies such as familial searching and forensic DNA phenotyping might help to generate intelligence for criminal investigations. Familial searching is a technology that attempts to identify criminal suspects through their genetic connection with relatives. Forensic DNA phenotyping makes it possible to focus on a particular suspect group that shares genetic ancestry and/or externally visible characteristics. The chapter critically reviews the existing debate in the field of social sciences about emerging DNA technologies. The core argument is that the application of DNA phenotyping and familial searching in the governance of crime holds the potential to increase risks of stigmatization and reinforce the criminalization of certain populations who are more vulnerable to the actions of the criminal justice system.
\end{abstract}

Keywords Intelligence $\bullet$ Familial searching • Forensic DNA phenotyping $\bullet$ Stigmatization $\bullet$ Criminalization

(C) The Author(s) 2020 


\section{From Evidence Towards Intelligence}

Since the establishment of the use of DNA technologies to support the activities in criminal justice systems worldwide, there has been an expansion in the breadth and reach of the potential ways they can be used. The applications of DNA technologies in the field of criminal justice systems include expanding the collection, storage and use of DNA profiles in forensic DNA databases (as covered in Chap. 5), the development of the exchange of DNA data among different countries within the context of police and judicial cooperation (see Chap. 6) and the speculative generation of criminal suspects based on information provided by DNA profiles - the topic which will form the basis for this chapter. In particular, this chapter addresses two emerging technologies in the field of forensic genetics: familial searching and forensic DNA phenotyping. The first refers to searches conducted in DNA databases to identify criminal suspects through their connection with relatives. Forensic DNA phenotyping is a set of techniques that allow inferring genetic ancestry and externally visible characteristics of criminal suspects on the basis of a DNA sample.

The ongoing development of these emergent DNA technologies represents a historical change in the presence of forensic genetic technologies in the criminal justice system. Firstly, because it shifts the focus of forensic science from the construction of evidence towards the generation of intelligence valuable to criminal investigations (Wienroth, 2018a). Secondly, such emergent DNA technologies move the locus from individualization, that is, identification of specific individuals, towards collectivization. It does so by clustering "suspect" populations which share biological links, genetic ancestry and/or externally visible characteristics. It is a process which the sociologist Simon Cole describes as the "convergence of individual and collective identification" (Cole, 2018, p. 2).

\section{Familial Searching in Forensic DNA Databases}

Familial searching is a term ${ }^{1}$ generally refers to searches conducted in forensic DNA databases to identify criminal suspects using their genetic connection to biological relatives (Debus-Sherrill \& Field, 2019; Granja \& Machado, 2019; Haimes, 2006; Kim, Mammo, Siegel, \& Katsanis,

\footnotetext{
${ }^{1}$ Other authors have proposed terms such as "low stringency search" (Gabel, 2010) or "genetic proximity testing" (Prainsack, 2010, p. 29) to describe this investigative technique.
} 
2011; Suter, 2010). Therefore, familial searching usually refers to a process through which a DNA profile that does not match any other profile contained in a criminal DNA database is subjected to a new analysis, in order to determine whether there are close matches. If such partial matches exist, it is probable that the profile obtained at the crime scene or from the victim(s) belongs to a close relative of the person in the database-usually parents, children or siblings.

One variation of such searches may occur when relatives of potential suspects are found among the DNA profiles collected by intelligence-led DNA massive screenings (Thomas, 2006). Another variant of familial searching might also occur when investigators find an inadvertent partial match while looking for a perfect correspondence between a certain DNA profile and the biological material found at a crime scene (Murphy, 2010, p. 9) - what Sara Debus-Sherrill and Michael Field call "partial matching" (Debus-Sherrill \& Field, 2019). The term familial searching in this chapter aims to encapsulate all its variations.

Familial searching in forensic DNA databases was first implemented in the UK in 2002 (Haimes, 2006; Prainsack, 2010) and its use has been expanding to other countries. The Netherlands and France introduced legislation that allows the use of this investigative technique (Maguire, McCallum, Storey, \& Whitaker, 2014) and, more recently, Germany has also approved the use of familial searching in intelligence-led DNA massive screenings (Criminal Code of Conduct-StPO $\$ 81 \mathrm{~h}$ ). In other EU countries, the situation remains unclear, although there are records of criminal cases that involved the use of relatives' DNA to search for criminal suspects in countries such as Spain, Poland (Dettlaff-Kakol \& Pawlowski, 2002) and Italy (Jones, 2015). Nevertheless, familial searching remains unregulated in most EU countries.

Beyond Europe, familial searching in forensic DNA databases was formally adopted by New Zealand and prohibited in Australia and Canada (Flaus, 2013; Thomas, 2006). The same kind of differentiation is found in the US, where familial searching is not conducted on a national level. On March 2008, the FBI determined that individual states should determine familial searching regulations. Following this decision, California was the first state to implement a policy for familial searching in 2008, followed by the state of Colorado in 2009. In 2011, Virginia also approved regulations on familial DNA searches, followed by Texas. More recently, in 2017, New York State also approved the use of this investigative technique. In contrast, Maryland and Washington, DC, banned familial searching. 
Additionally, some states have implemented specific regulations permitting partial match disclosure, such as Arizona, Connecticut, Florida, Missouri, Nebraska, Nevada, Oregon, Washington State and Wyoming (Kim et al., 2011).

In countries where familial searching in forensic DNA databases is regulated, guidelines are typically restrictive and allow its use only in certain criminal cases which are considered serious and difficult to solve through other means (Chamberlain, 2012). For example, in the UK, familial searches conducted in the National DNA Database (NDNAD) are analysed according to a case-by-case approach and are dependent on permission from the Chairman of the NDNAD Strategy Board and, in some cases, from the victim (Maguire et al., 2014). Despite its restrictive use, such investigative techniques have thus far produced information that has helped to identify suspects, convict offenders and exonerate wrongfully convicted individuals, both in cold and in non-cold cases in several countries (Kim et al., 2011). Nevertheless, the use of familial searching in forensic databases is still full of legal, ethical and social controversies (Chamberlain, 2012; García, Crespillo, \& Yurrebaso, 2017; Haimes, 2006; Kim et al., 2011; Maguire et al., 2014; Murphy, 2010; Nuffield Council on Bioethics, 2007; Suter, 2010).

The academic and public debate around familial searching can be summarized as framed around three main dimensions: genetic privacy, information disclosure and reproduction of social inequalities. The first is related to how familial searching might constitute a "function creep" (Prainsack, 2010, pp. 28-30), inasmuch as it expands the reach of forensic databases to include, even if indirectly, other people who might never have had any direct contact with the criminal justice system (Bieber, Brenner, \& Lazer, 2006; Epstein, 2009; Flaus, 2013; Suter, 2010; Thomas, 2006). This potential involvement of innocent people implies that this investigative technique increases indirect genetic surveillance on a certain group of individuals - relatives of potential suspects - primarily on the basis of their genetic association with someone (Bieber et al., 2006; Greely, Riordan, Garrison, \& Mountain, 2006; Haimes, 2006; Kim et al., 2011; Lazer, 2008; Murphy, 2010). By extension, the expansion of the reach of forensic databases also fosters a debate about the rights and duties of the "genetic informant", that is, the person whose sample is a partial match with the crime scene sample and who, unintentionally, implicates family members in criminal investigations (Gabel, 2010; Murphy, 2010; Suter, 2010; Williams \& Johnson, 2006, p. 16). 
The second dimension concerns the latent risk of familial searching disclosing information. This might relate to either the absence or the existence of genetic relations (Haimes, 2006; Kim et al., 2011; Nuffield Council on Bioethics, 2007; Suter, 2010) and/or to the involvement with the criminal justice system that remained unknown to others.

The third dimension regards the broader social implications of familial searching, in particular its potential to reinforce dominant views about the alleged prevalence of criminality within certain families (Gabel, 2010, p. 21; Haimes, 2006) and/or to further amplify inequalities. When conducted in forensic DNA databases, this investigative technique searches for potential suspects on a pre-established pool that generally overrepresents certain groups and social categories that are most affected by the actions of the criminal justice system, such as racial and ethnic minorities (Chow-White \& Duster, 2011; Duster, 2003; Skinner, 2013). In this sense, familial searching might end up reproducing the criminalization of certain social groups (Bieber et al., 2006; Epstein, 2009; Flaus, 2013; Greely et al., 2006; Grimm, 2007; Kim et al., 2011; Lazer, 2008; Murphy, 2010; Suter, 2010; Thomas, 2006).

Despite the lively debate that familial searching has been fomenting over the years, there are scarce empirical studies on this topic. One of them entails a National Survey of CODIS Laboratories in the US about policies and practices, as well as professionals' perceptions, as they relate to familial searching (Debus-Sherrill \& Field, 2019). Results show that while perceptions over familial searching were generally positive, with most respondents $(87 \%)$ believing that familial searching has potential to assist investigations, laboratories still shared a number of concerns related to familial searching. In addition to resource issues, which were indicated as the main concern, $83 \%$ of respondents working in a lab that conducts familial searching reported concerns over challenges to civil liberties, compared to $30 \%$ of respondents working in labs that do not conduct such genetic technique (Debus-Sherrill \& Field, 2019).

To date, only one empirical study on the topic of familial searching is known to have been undertaken in Europe. Based on a comparative study between the uses of familial searching in the UK and Poland, Rafaela Granja and Helena Machado outline the variability of familial searching in terms of meanings, uses and regulations (Granja \& Machado, 2019). In the UK, familial searching is regulated by exceptionality and is mainly used for the identification of suspects in serious criminal cases. In Poland, familial searching is regulated within the framework of expanding the scope of 
its application to the search and/or identification of missing persons. This chapter thereby shows how familial searching prescribes particular notions of social risks, public good and the accountability of the state. The elements that coproduce the different ways of perceiving ethical controversies about familial searching carry with them the weight of sociohistorical and techno-political backgrounds, the influence of distinctive forms of state accountability as well as the contingent and circumstantial character of what each society considers the socially legitimate uses of genetic technologies (Granja \& Machado, 2019).

\section{Long-Range Familial Searches in Recreational DNA DATABASES}

The existing discussion on familial searching suffered a major turning point in 2018, following the aftermath of the Golden State Killer ${ }^{2}$ criminal investigation. In that case, criminal investigators used DNA from crime scenes and uploaded the genetic information into an online public-access DNA database, GEDmatch. ${ }^{3}$ Based on that search, officers found partial matches with the profile of the presumed suspect, which were assumed to belong to distant relatives. Following up the partial match, family trees were built upon the basis of several other sources (social media and other types of online records) and Joseph James DeAngelo, 72 years old, was identified as a suspect and his "abandoned" DNA ${ }^{4}$ was collected to conduct further analysis. The result of the tests confirmed it matched the crime scene samples. ${ }^{5}$

\footnotetext{
${ }^{2}$ The Golden State Killer is the name coined by Michelle McNamara to refer to a serial killer and rapist who committed at least 12 murders, and more than 50 rapes in California, USA, from 1974 to 1986 . He is believed to be responsible for three crime sprees throughout California, each of which spawned a different nickname in the press (East Area Rapist and Original Night Stalker) before it became evident, through DNA analysis, that they were committed by the same person.

${ }^{3}$ GEDmatch is an online public-access database where individuals with data originated from different testing companies can compare their DNA with others on the database in order to trace relatives. More information here: https://www.gedmatch.com/loginl.php (last accessed 13 May 2019).

${ }^{4}$ In the US the police can collect "abandoned DNA", that is, a biological sample which has been left behind by the individual inadvertently or involuntarily, such as chewing gum or a tip of a cigarette. For a critical view of such procedures see Joh (2006).

${ }^{5}$ Writing dated from September 2019; the case is currently under trial.
} 
The Golden State Killer criminal case was not the first one using longrange familial cases to assist criminal investigations (Erlich, Shor, Pe'er, \& Carmi, 2018). However, since it became a widely discussed and highprofile criminal case, it completely reframed the discussion around the use of familial searching in criminal investigations. The case was considered by Nature one of the scientific events that shaped the year of 2018 (Abbott et al., 2018). Barbara Rae-Venter, a genealogist who helped to identify the Golden State Killer, was distinguished by the same journal as one of the "Ten people who mattered this year". According to Time, Barbara RaeVenter "has provided law enforcement with its most revolutionary tool since the advent of forensic DNA testing in the 1980s" (Holes, 2019).

The use of non-forensic DNA databases for criminal investigation purposes is not a new phenomenon. There are a few criminal cases where information stored, for example, in medical DNA databases was used to solve a criminal case. ${ }^{6}$ However, the Golden State Killer criminal case led to the first reports of recreational DNA databases being used in such enquiries. That is, databases held for commercial purposes-the so-called direct-to-consumer (DTC) genetic testing-to which citizens voluntarily upload their DNA in order to know about their ancestry and other genetic information, such as health issues (Abel, 2018; Borry, Cornel, \& Howard, 2010; Chow-White et al., 2018; Horowitz, Saperstein, Little, Maiers, \& Hollenbach, 2019).

In the aftermath of the Golden State Killer investigation, other criminal cases have been showing the increasing use of long-range familial searches in recreational DNA databases, with the purpose of accommodating the possibility of searching for criminal suspects. According to Erlich et al. (2018), between April and August 2018, 13 criminal cases in the US were solved through such searches. A significant portion of those had the involvement of Parabon NanoLabs, a company offering forensic services such as genetic genealogy, kinship inference and forensic DNA phenotyping (in this respect see also Wienroth, 2018a). In a more recent publication, members of the company refer to more than 30 law enforcement cases $^{7}$ solved by them and their collaborators, such as Barbara Rae-Venter and law enforcement agencies (Greytak, Moore, \& Armentrout, 2019).

${ }^{6}$ In Sweden, in 2003, forensic access to a medical biobank (PKU biobank-diagnostics) was authorized as part of the murder investigation of Anna Lindh (Swedish foreign minister).

${ }^{7}$ Through $31 / 1 / 19$. 
As a result, the use of long-range familial searches in recreational DNA databases has been the subject of highly visible public and regulatory controversy, posing new lines of enquiry on the uses of DNA data in the governance of crime. In the rest of this section, we will briefly summarize some of the topics under discussion.

Familial searching in forensic DNA databases uses autosomal short tandem repeats (STRs), the so-called junk genes that presumably hold little value other than for identification. Using that method, the investigative technique might, at best, identify close biological relatives (siblings, parents or children). In opposition, long-range familial searches in recreational DNA databases use single-nucleotide polymorphisms (SNPs), which are characterized by their informational richness (Greytak et al., 2019; Kennett, 2019; Murphy, 2018). ${ }^{8}$ As a result, that kind of use makes more informative data available to law enforcement, while also significantly expanding the network of people that might be affected by such procedures (Murphy, 2018). In this respect it is relevant to note that a study conducted by Yaniv Erlich and his colleagues estimates that "about $60 \%$ of the searches for individuals of European descent will result in a third cousin or a closer match, which can allow their identification using demographic identifiers" (Erlich et al., 2018). The use of long-range familial searches in recreational DNA databases thereby significantly expands the scope and impact of genetic surveillance.

Forensic DNA databases and recreational DNA databases also significantly differ in another aspect that has become increasingly relevant in the governance of crime. While the first tends to overrepresent the groups and social categories most affected by the actions of the criminal justice system, such as racial and ethnic minorities (Skinner, 2013), the latter is mainly composed of individuals with a North European genetic background (Erlich et al., 2018). This, therefore, implies that genetic surveillance is no longer restricted to the "management of those already deemed criminal" (Williams \& Johnson, 2004, p. 11): nowadays it also encapsulates individuals that might never have had contact with the criminal justice system before.

Another topic of discussion regarding long-range familial searches in recreational DNA databases relates to the lack of governance and over-

\footnotetext{
${ }^{8}$ In addition to this, since DTC companies obtain DNA from spit kits or cheek swabs, DNA profiles are always based on a large amount of high-quality single-source DNA. In opposition, forensic DNA samples might face several obstacles to an analysis by having only a small amount of degraded DNA and/or being mixed with DNA from other individuals (Greytak et al., 2019).
} 
sight. In the aftermath of the Golden State Killer criminal case, several private companies specialized in providing direct-to-consumer DNA tests and other online related resources updated their terms of use. However, due to the lack of regulatory norms, several companies in the market reacted differently. Some companies had decided to not allow uploads in their databases, stating that their data is not accessible to law enforcement unless a judicial request is made (Greytak et al., 2019; Kennett, 2019). However, the private company FamilyTreeDNA admitted in February 2019 that, without informing its users, it allowed the FBI to upload genetic profiles created from crime scenes and corpses. After the company's president, Bennett Greenspan, apologized for not revealing it sooner to its clients, the company produced a TV advertisement urging consumers to help them catch criminals. The television spot ${ }^{9}$ asked anyone who had made a direct-to-consumer DNA test to upload a copy so that law enforcement could spot any connections to DNA found at crime scenes.

Finally, GEDmatch, the online public-access database used in the Golden State Killer case, changed their Terms of Service. Since May 2019 users have to explicitly opt in for their DNA profiles to be included in law enforcement searches to identify remains and perpetrators of violent crimes, defined as homicides or sexual assaults (Kennett, 2019; Moore, 2016). Although it is acceptable to expect that users of such databases are currently informed about its wide implications, such policies do not secure consent from the biological relatives that might, unexpectedly, become implicated into a criminal investigation.

Therefore, the different approaches taken by different companies and other online resources mobilized for long-range familial searches exemplify the lack of restrictions and constraints currently under place to balance the right of individuals to genetic privacy against the desire to apprehend criminals (Murphy, 2018). In addition to such a scenario, another layer of this lack of governance and oversight is linked to the inexistence of accreditation, professionalization and accountability for genealogists. As a result, individuals with very different degrees of expertise might be involved in such procedures, which poses severe ethical issues (Kennett, 2019).

Within such a complex scenario, it is clear that while familial searching in forensic DNA databases is framed by a series of inclusion and exclusion criteria that impose some safeguards in terms of genetic privacy (Granja \&

\footnotetext{
${ }^{9}$ https://www.technologyreview.com/the-download/613232/help-us-catch-killers-isnow-the-new-advertising-angle-for-dna-companies/ (last accessed on 29 April 2019).
} 
Machado, 2019; Haimes, 2006; Kim et al., 2011; Murphy, 2010, 2018), private companies have extensive databases, with few restrictions and inexistent governance. Long-range familial searches in recreational DNA databases thus offer a way of circumventing long-established protocols in forensic DNA databases.

Despite such a spirited debate taking place, little is yet known about how the public perceives such new avenues of criminal investigation. In the aftermath of the Golden State Killer criminal case, a survey of 1587 US residents found that the majority of respondents supported police searches of genetic websites that identify genetic relatives $(79 \%)$ and the disclosure of direct-to-consumer genetic testing customer information to the police $(62 \%)$, as well as the creation of fake profiles of individuals by the police on genealogy websites $(65 \%)$. However, respondents were significantly more supportive of these activities to identify perpetrators of violent crimes, perpetrators of crimes against children and missing persons cases (Guerrini, Robinson, Petersen, \& McGuire, 2018).

Old and new debates over the use of familial searches for criminal investigation purposes therefore shed light on how we are no longer solely discussing an interaction between science and law. The advent of longrange familial searches in recreational databases puts in focus how police forces, scientific experts, private companies, media and consumers increasingly interact. Such scenario thus brings to the table issues of trust and distrust, citizens' understanding of genetic science, uncontrolled access to citizens' genetic data and expansion of affected populations. Although such uses of recreational databases are, for now, mainly restricted to the US context, this type of databases are increasingly expanding worldwide. As a result, it is possible that law enforcement agencies in other countries will consider using such investigative technique.

\section{Forensic DNA Phenotyping}

Forensic DNA phenotyping can be broadly described as a constellation of techniques ${ }^{10}$ that aims to infer externally visible physical features in humans-eye, hair and skin colour-and continental-based biogeographi-

\footnotetext{
${ }^{10}$ We use the term "constellation" to define forensic DNA phenotyping and outline the set of different genetic techniques that might be used to infer externally visible characteristicssuch as eye, skin and hair colour - as well as information about biogeographic ancestry. In addition, the use of this term also aims to highlight how such techniques can be used either jointly or separately.
} 
cal ancestry of criminal suspects, through the analysis of biological materials collected at crime scenes ${ }^{11}$ (Daniel et al., 2015; Kayser, 2015; Kayser \& de Knijff, 2011; Kayser \& Schneider, 2009). Forensic DNA phenotyping technologies have been applied in various jurisdictions in a limited number of high-profile cases (Wienroth, 2018a, p. 4) with the aim of providing intelligence for criminal investigations.

The potentialities attributed to forensic DNA phenotyping in supporting criminal investigations show its added intelligence value by generating new leads when the DNA collected from crime scenes is not registered in forensic DNA databases and/or when there are no eyewitnesses available (Kayser, 2015). ${ }^{12}$ More particularly, forensic DNA phenotyping works by inferring to which group a particular individual might belong (i.e., a group of people with blue eyes and European ancestry). Within a criminal investigation, such type of data is translated by clustering a group of people who share a set of characteristics and considering them "a suspect population" (M'charek, 2008).

The initial debate in the field of social sciences about this genetic technology has primarily focused on the socio-ethical challenges that might emerge from its use in the criminal justice system. For the purposes of this chapter, we outline three domains that have been extensively debated. The first regards the high expectations placed upon the potential of forensic DNA phenotyping. Contrary to what is often disseminated in popular media when this topic is touched upon, forensic geneticists argue that forensic DNA phenotyping tests cannot "predict" the external characteristics of a person or his/her ancestry with fool-proof certainty. Such interpretation of the potential of forensic DNA phenotyping might lead to severe miscarriages of justice. According to such professionals, forensic DNA phenotyping's potential lies in the inference of individual's phenotypic characteristics within a certain degree of probabilistic likelihood

${ }^{11}$ For the purposes of this chapter, we excluded the potential uses of this technology in the search and/or identification of missing persons.

${ }^{12}$ Legislation about the use of forensic DNA phenotyping differs widely across Europe. It is only explicitly regulated in the Netherlands (Samuel \& Prainsack, 2018a, 2018b). In other countries, legislation is either implicit or absent, which implies that it might be differently interpreted by experts and practitioners. As a result, forensic DNA phenotyping is applied in countries such as Spain and the UK and considered as forbidden in others, namely, Germany, Belgium and Austria. Nevertheless, there are ongoing debates and proposals on the regulation of forensic DNA phenotyping in both Germany and Switzerland (Samuel \& Prainsack, 2018a). 
(Samuel \& Prainsack, 2018a). These expanding high expectations are further complicated by the claims made by the company Parabon NanoLabs, which markets forensic DNA phenotyping as a technology able to produce facial composite images of potential suspects, including facial features and morphology. Claims of that kind have been extensively criticized by criminal justice stakeholders and scientific practitioners who research and work in the field of forensic DNA phenotyping (Wienroth, 2018b).

The second area of debate regarding forensic DNA phenotyping that has been receiving wide attention refers to the problematic nature of defining populations through genetics. In particular, scholars in social sciences outline the need to problematize how the genetic reinscription of race (El-Haj, 2007) might play out in the everyday practices of criminal investigations. That is, how socially constructed notions of "race" and "ethnicity" might be translated into biological characteristics and vice versa. For example, stating that the criminal suspect is possibly from "African ancestry" is probably going to be translated and materialized by law enforcement, justice stakeholders and the general public into "the suspect is probably black" (Samuel \& Prainsack, 2018a). In this sense, disclosing information related to biogeographical ancestry is a sensitive issue, as the forensic distinction of populations by continents or population groups can easily lead to inaccurate socially constructed associations between these and categories of race and ethnicity (M'charek, 2008; Vailly, 2017).

In addition, the act of revealing that a certain criminal suspect is from a racial or ethnic minority might further compound discriminatory practices against already vulnerable groups. Forensic DNA phenotyping might, thus, present a risk of renewing existing forms of stigmatization and creating new forms of racial profiling that further exacerbate the criminalization of certain groups, which are already the most affected by the actions of the criminal justice system, such as racial and ethnic minorities (M'charek, Toom, \& Prainsack, 2012).

The third area under discussion concerns the idea that forensic DNA phenotyping might be used in criminal investigations as a "biological witness" (Kayser, 2015). Such a concept encapsulates the notion that forensic DNA phenotyping techniques might overcome the limitations of information presented by eyewitness testimonies, which are perceived as fragile, pervaded with emotions, motivations, subjectivities and information gaps. When reacting to that argument, several social scientists have been outlining, on the one hand, the risks of perceiving science and technology as 
immune to social bias, and, on the other, the socially decontextualized nature of information provided by forensic DNA phenotyping, especially when directly compared with eyewitness accounts that often provide context about the events of a crime (Toom et al., 2016).

In addition to such debates about the ethical, legal and social implications of forensic DNA phenotyping, the topic has been increasingly raising interest from scholars. Richard Tutton and his colleagues have critically explored the UK Border Agency's initiative of using genetic testing to discover ancestry and geographical origins and isotope testing ${ }^{13}$ to corroborate asylum seekers' accounts of their nationality (Tutton, Hauskeller, \& Sturdy, 2014). The authors outline how such technologies deprive individuals of the right to tell their own stories by employing biological categories as a proxy for the social category of nationality (Tutton et al., 2014, p. 746) and further aggravate the criminalization of asylum applicants. Another study, by Joëlle Vailly, analysed the power relations which emerged in France in relation to forensic DNA phenotyping through an analysis of the discourses of judges and prosecutors, political officials and managers in biotechnology companies. The author shows how such power relations emerged between different social actors, according to their different connections and affiliations to ethics, politics and law (Vailly, 2017).

Another recent study has addressed the views of forensic geneticists about forensic DNA phenotyping by focusing on how scientists engage with a set of anticipatory practices (Wienroth, 2018a). Mathias Wienroth explores the promissory aspects of forensic DNA phenotyping, along with its epistemic and operational aspects-such as management of expectations, negotiation of legislative barriers and integration into existing technologies. In a different piece of work, Wienroth also analyses how forensic DNA phenotyping is entrenched in the political economy of forensic genetics, anchored in the intersection of scientific ethics, forensic practices and commercial resources. Drawing on the case of Parabon NanoLabs' DNA photo-fits, the author outlines how scientists' ethical reasoning about the development and use of forensic DNA phenotyping tackles issues of validation, epistemic transparency, science legitimacy and commercial value in ways that continuously reassert scientific primacy over commercial, legal and judicial concerns (Wienroth, 2018b).

Gabrielle Samuel and Barbara Prainsack have also recently written publications about forensic DNA phenotyping. In one of such publications

\footnotetext{
${ }^{13}$ Isotope testing analyses the way different environments may leave distinctive traces in individuals' bodies (Tutton et al., 2014, pp. 744-745).
} 
the authors address the views of actors with a professional stake in forensic DNA phenotyping about the benefits and problems associated with the prospective use of the technology. More particularly, Samuel and Prainsack show how respondents do not "view forensic DNA phenotyping as a technology with clear boundaries that 'raised' ethical issues. Instead, forensic DNA phenotyping was portrayed as a heterogeneous set of practices and material technologies that were partly shaped by ethical considerations" (Samuel \& Prainsack, 2018a, pp. 3-4), which include issues of validity, reliability and discrimination. In another publication, the authors explore how civil society stakeholders strike a balance between the potential usefulness of the use of forensic DNA phenotyping and the various ethical and social considerations (Samuel \& Prainsack, 2019).

Finally, David Skinner has addressed the topic of why race prediction within forensic DNA phenotyping is particularly problematic. The author discusses the implications of and for forensic DNA phenotyping in the context of established social structural inequalities that affect minorities in the realm of police and justice (Skinner, 2018a). Moreover, the author also frames forensic DNA phenotyping as entrenched in wider significant changes in the use of race as an object of expert knowledge in science and policy-making (Skinner, 2018b).

Despite the still-evolving controversies on forensic DNA phenotyping in several countries, further development of intelligence-focused technologies is being equated: a recent publication, for instance, argues in favour of broadening DNA-based forensic intelligence by coupling it with epigenomic lifestyle predictions to find unknown perpetrators of crimes who are not identifiable using current forensic DNA profiling (Vidaki \& Kayser, 2017,2018 ). Building upon the concept and possibilities of epigenetics (covered in Chap. 3), some forensic geneticists are thereby considering that future perspectives of forensic epigenomics might include the ability to predict smoking, drinking and drug-use habits, the type of diet followed, physical activity levels, body size/shape, geographic region of residence as well as socioeconomic status (Vidaki \& Kayser, 2017).

\section{Concluding Remarks}

This chapter aimed to critically explore the complex politics of legitimation and contestation (Skinner, 2018b) that frame the development and consolidation of DNA technologies focused on generating intelligence, such as familial searching and forensic DNA phenotyping. Such technolo- 
gies represent particularly interesting cases to question the role of forensic genetics in the governance of crime. Firstly, despite the association with notions of a "gold standard" that frames forensic science, recent and still developing technologies present ongoing issues about their usefulness, reliability and regulatory framework. Nevertheless, developers and advocates for its adoption strongly draw upon a narrative of objectivity to bolster its adoption, further development and expansion (Wienroth, 2018a). Secondly, by constructing suspicion as collective, rather than individual, such technologies also bring an additional layer to issues of discrimination. Finally, such technologies are also clearly outlining how modern science will unravel under the aegis of the market, which brings complex consequences and contingencies for human rights.

\section{REFERENCES}

Abbott, A., Butler, D., Castelvecchi, D., Cressey, D., Gibney, E., Ledford, H., ... Witze, A. (2018). 2018 in news: The science events that shaped the year. Nature. https://www.nature.com/articles/d41586-018-07685-3

Abel, S. (2018). What DNA can't tell: Problems with using genetic tests to determine the nationality of migrants. Anthropology Today, 34(6), 3-6. https://doi. org/10.1111/1467-8322.12470

Bieber, F. R., Brenner, C. H., \& Lazer, D. (2006). Finding criminals through DNA of their relatives. Human Genetics, 312, 1315-1316. https://doi. org/10.1126/science.1122655

Borry, P., Cornel, M. C., \& Howard, H. C. (2010). Where are you going, where have you been: A recent history of the direct-to-consumer genetic testing market. Journal of Community Genetics, 1(3), 101-106. https://doi.org/10.1007/ s12687-010-0023-z

Chamberlain, M. (2012). Familial DNA searching. A proponent's perspective. Criminal Justice, 27(1).

Chow-White, P., \& Duster, T. (2011). Do health and forensic DNA databases increase racial disparities? PLoS Medicine, 8(10), el001100. https://doi. org/10.1371/journal.pmed.1001100

Chow-White, P., Struve, S., Lusoli, A., Lesage, F., Saraf, N., \& Oldring, A. (2018). 'Warren Buffet is my cousin': Shaping public understanding of big data biotechnology, direct-to-consumer genomics, and 23andMe on Twitter. Information Communication and Society, 21(3), 448-464. https://doi.org/1 $0.1080 / 1369118 X .2017 .1285951$

Cole, S. (2018). Individual and collective identification in contemporary forensics. BioSocieties, 1-26. https://doi.org/10.1057/s41292-018-0142-z 
Daniel, R., Santos, C., Phillips, C., Fondevila, M., Van Oorschot, R., Carracedo, Á., ... McNevin, D. (2015). A SNaPshot of next generation sequencing for forensic SNP analysis. Forensic Science International: Genetics, 14, 50-60. https://doi.org/10.1016/j.fsigen.2014.08.013

Debus-Sherrill, S., \& Field, M. B. (2019). Familial DNA searching - An emerging forensic investigative tool. Science \& Justice, 59(1), 20-28. https://doi. org/10.1016/j.scijus.2018.07.006

Dettlaff-Kakol, A., \& Pawlowski, R. (2002). First Polish DNA “manhunt” - An application of Y-chromosome STRs. International Journal of Legal Medicine, 116(5), 289-291. https://doi.org/10.1007/s00414-002-0320-0

Duster, T. (2003). Backdoor to eugenics. New York: Routledge.

El-Haj, N. A. (2007). The genetic reinscription of race. Annual Review of Anthropology, 36(1), 283-300. https://doi.org/10.1146/annurev.anthro.34. 081804.120522

Epstein, J. (2009). "Genetic surveillance" - The Bogeyman response to familial DNA investigations. Journal of Law, Technology and Policy, 1, 141-173. https://doi.org/10.2139/ssrn.1129306

Erlich, Y., Shor, T., Pe'er, I., \& Carmi, S. (2018). Identity inference of genomic data using long-range familial searches. Science, 362(6415), 690-694. https:// doi.org/10.1126/science.aau4832

Flaus, A. (2013). Familial searches and the New Zealand DNA profile databank: The thin edge of the genetic wedge? University of Otago. Retrieved from http:// www.otago.ac.nz/law/research/journals/otago065282.pdf

Gabel, J. D. (2010). Probable cause from probable bonds: A genetic tattle tale based on familial DNA. Hastings Women's Law Journal, 21(3), 3-58. Retrieved from http://ssrn.com/abstract=1495128

García, Ó., Crespillo, M., \& Yurrebaso, I. (2017). Suspects identification through "familial searching" in DNA databases of criminal interest. Social, ethical and scientific implications. Spanish Journal of Legal Medicine, 43(1), 26-34. https://doi.org/10.1016/j.remle.2017.02.002

Granja, R., \& Machado, H. (2019). Ethical controversies of familial searching: The views of stakeholders in the United Kingdom and in Poland. Science, Technology, \& Human Values, 44(6), 1068-1092. https://doi. org/10.1177/0162243919828219

Greely, H. T., Riordan, D. P., Garrison, N. A., \& Mountain, J. L. (2006). Family ties: The use of DNA offender databases to catch offenders' kin. Journal of Law, Medicine of Ethics, 34(2), 248-262. https://doi.org/10.1111/ j.1748-720X.2006.00031.x

Greytak, E. M., Moore, C., \& Armentrout, S. L. (2019). Genetic genealogy for cold case and active investigations. Forensic Science International: Genetics, 299, 103-113. https://doi.org/10.1016/j.forsciint.2019.03.039 
Grimm, D. J. (2007). The demographics of genetic surveillance: Familial DNA testing and the Hispanic community. Columbia Law Review, 107(5), 1164-1194.

Guerrini, C. J., Robinson, J. O., Petersen, D., \& McGuire, A. L. (2018). Should police have access to genetic genealogy databases? Capturing the Golden State Killer and other criminals using a controversial new forensic technique. PLoS Biology, 16(10), e2006906. https://doi.org/10.1371/journal.pbio.2006906

Haimes, E. (2006). Social and ethical issues in the use of familial searching in forensic investigations: Insights from family and kinship studies. Journal of Law, Medicine \& Ethics, 34(2), 263-276. https://doi.org/10.1111/ j.1748-720X.2006.00032.x

Holes, P. (2019). Barbara Rae-Venter. Time 100 Most Influential People 2019. Times. https://time.com/collection/100-most-influential-people-2019/ $5567712 /$ barbara-rae-venter/

Horowitz, A. L., Saperstein, A., Little, J., Maiers, M., \& Hollenbach, J. A. (2019). Consumer (dis-)interest in genetic ancestry testing: The roles of race, immigration, and ancestral certainty. New Genetics and Society, 1-30. https://doi.org/ $10.1080 / 14636778.2018 .1562327$

Joh, E. E. (2006). Reclaiming "Abandoned" DNA: The fourth amendment and genetic privacy. Northwestern University Law Review, 100(2), 857-884.

Jones, T. (2015, January). The murder that has obsessed Italy. The Guardian.

Kayser, M. (2015). Forensic DNA phenotyping: Predicting human appearance from crime scene material for investigative purposes. Forensic Science International: Genetics, 18, 33-48. https://doi.org/10.1016/j.fsigen.2015. 02.003

Kayser, M., \& de Knijff, P. (2011). Improving human forensics through advances in genetics, genomics and molecular biology. Nature Reviews Genetics, 12(3), 179-192. https://doi.org/10.1038/nrg2952

Kayser, M., \& Schneider, P. (2009). DNA-based prediction of human externally visible characteristics in forensics: Motivations, scientific challenges, and ethical considerations. Forensic Science International: Genetics, 3(3), 154-161. https://doi.org/10.1016/j.fsigen.2009.01.012

Kennett, D. (2019). Using genetic genealogy in missing persons cases and to develop suspect leads in violent crimes. Forensic Science International: Genetics, 301, 107-117. https://doi.org/10.1016/j.forsciint.2019.05.016

Kim, J., Mammo, D., Siegel, M., \& Katsanis, S. (2011). Policy implications for familial searching. Investigative Genetics, 2(1), 1-22. https://doi.org/10. 1186/2041-2223-2-22

Lazer, D. (2008). Searching the family tree for suspects: Ethical and implementation issues in the familial searching of DNA databases. Taubman Center Policy Briefs, (March), 1-8. 
M'charek, A. (2008). Silent witness, articulate collective: DNA evidence and the inference of visible traits. Bioethics, 22(9), 519-528. https://doi.org/10. $1111 / j .1467-8519.2008 .00699 . x$

M'charek, A., Toom, V., \& Prainsack, B. (2012). Bracketing off population does not advance ethical reflection on EVCs: A reply to Kayser and Schneider. Forensic Science International: Genetics, 6, el6-e17. https://doi. org/10.1016/j.fsigen.2010.12.012

Maguire, C., McCallum, L. L., Storey, C., \& Whitaker, J. (2014). Familial searching: A specialist forensic DNA profiling service utilising the National DNA Database ${ }^{\circledR}$ to identify unknown offenders via their relatives-The UK experience. Forensic Science International: Genetics, 8(1), 1-9. https://doi.org/10. 1016/j.fsigen.2013.07.004

Moore, C. (2016). The history of genetic genealogy and unknown parentage research: An insider's view. Journal of Genetic Genealogy, 8(1), 35-37.

Murphy, E. (2010). Relative doubt: Familial searches of DNA databases. Michigan Law Review, 109(3), 291-348. https://repository.law.umich.edu/cgi/viewcontent.cgi?article $=1169 \&$ context $=\mathrm{mlr}$

Murphy, E. (2018). Law and policy oversight of familial searches in recreational genealogy databases. Forensic Science International: Genetics, 292, e5-e9. https://doi.org/10.1016/J.FORSCIINT.2018.08.027

Nuffield Council on Bioethics. (2007). The forensic use of bioinformation: Ethical issues. London. https://nuffieldbioethics.org/assets/pdfs/The-forensic-useof-bioinformation-ethical-issues.pdf

Prainsack, B. (2010). Key issues in DNA profiling and databasing: Implications for governance. In R. Hindmarsh \& B. Prainsack (Eds.), Genetic suspects: Global governance of forensic DNA profiling and databasing (pp. 153-174). Cambridge: Cambridge University Press.

Samuel, G., \& Prainsack, B. (2018a). Forensic DNA phenotyping in Europe: views "on the ground" from those who have a professional stake in the technology. New Genetics and Society, 1-23. https://doi.org/10.1080/14636778. 2018.1549984

Samuel, G., \& Prainsack, B. (2018b). The regulatory landscape of forensic DNA phenotyping in Europe. VISAGE. Retrieved from http://www.visage-h2020. eu/Report_regulatory_landscape_FDP_in_Europe2.pdf

Samuel, G., \& Prainsack, B. (2019). Civil society stakeholder views on forensic DNA phenotyping: Balancing risks and benefits. Forensic Science International: Genetics, 43, 102157. https://doi.org/10.1016/j.fsigen.2019.102157

Skinner, D. (2013). "The NDNAD has no ability in itself to be discriminatory": Ethnicity and the governance of the UK National DNA Database. Sociology, 47(5), 976-992. https://doi.org/10.1177/0038038513493539

Skinner, D. (2018a). Forensic genetics and the prediction of race: What is the problem? BioSocieties, 1-21. https://doi.org/10.1057/s41292-018-0141-0 
Skinner, D. (2018b). Race, racism and identification in the era of technosecurity. Science as Culture, 1-23. https://doi.org/10.1080/09505431.2018.1523887

Suter, S. M. (2010). All in the family: Privacy and DNA familial searching. Harvard Journal of Law \& Technology, 23(2), 309-399.

Thomas, L. (2006). Nothing to hide, something to fear?: The use of partial DNA matching in criminal investigations. Journal of Law, Information and Science, $17,72-93$.

Toom, V., Wienroth, M., M'charek, A., Prainsack, B., Williams, R., Duster, T., ... Murphy, E. (2016). Approaching ethical, legal and social issues of emerging forensic DNA phenotyping (FDP) technologies comprehensively: Reply to 'Forensic DNA phenotyping: Predicting human appearance from crime scene material for investigative purposes' by Manfred Kayser. Forensic Science International: Genetics, 22, el-e4. https://doi.org/10.1016/j.fsigen.2016. 01.010

Tutton, R., Hauskeller, C., \& Sturdy, S. (2014). Suspect technologies: Forensic testing of asylum seekers at the UK border. Ethnic and Racial Studies, 37(5), 738-752. https://doi.org/10.1080/01419870.2013.870667

Vailly, J. (2017). The politics of suspects' geo-genetic origin in France: The conditions, expression, and effects of problematisation. BioSocieties, 12(1), 66-88. https://doi.org/10.1057/s41292-016-0028-x

Vidaki, A., \& Kayser, M. (2017). From forensic epigenetics to forensic epigenomics: Broadening DNA investigative intelligence. Genome Biology, 18(1), 238. https://doi.org/10.1186/s13059-017-1373-1

Vidaki, A., \& Kayser, M. (2018). Recent progress, methods and perspectives in forensic epigenetics. Forensic Science International: Genetics, 37(July), 180195. https://doi.org/10.1016/j.fsigen.2018.08.008

Wienroth, M. (2018a). Governing anticipatory technology practices. Forensic DNA phenotyping and the forensic genetics community in Europe. New Genetics and Society, 1-16. https://doi.org/10.1080/14636778.2018. 1469975

Wienroth, M. (2018b). Socio-technical disagreements as ethical fora: Parabon NanoLab's forensic DNA Snapshot ${ }^{\mathrm{TM}}$ service at the intersection of discourses around robust science, technology validation, and commerce. BioSocieties. https://doi.org/10.1057/s41292-018-0138-8

Williams, R., \& Johnson, P. (2004). Circuits of surveillance. Surveillance \& Society, 2(1), 1-14. https://ojs.library.queensu.ca/index.php/surveillance-and-society/article/view/3324

Williams, R., \& Johnson, P. (2006). Inclusiveness, effectiveness and intrusiveness: Issues in the developing uses of DNA profiling in support of criminal investigations. Journal of Law, Medicine \& Ethics, 33(3), 545-558. https://doi. org/10.1111/j.1748-720X.2005.tb00517.x 
Open Access This chapter is licensed under the terms of the Creative Commons Attribution 4.0 International License (http://creativecommons.org/licenses/ by $/ 4.0 /$ ), which permits use, sharing, adaptation, distribution and reproduction in any medium or format, as long as you give appropriate credit to the original author(s) and the source, provide a link to the Creative Commons licence and indicate if changes were made.

The images or other third party material in this chapter are included in the chapter's Creative Commons licence, unless indicated otherwise in a credit line to the material. If material is not included in the chapter's Creative Commons licence and your intended use is not permitted by statutory regulation or exceeds the permitted use, you will need to obtain permission directly from the copyright holder.

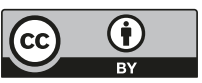




\title{
Conclusion
}

\begin{abstract}
This chapter succinctly summarizes the contents presented in the book, highlighting the main arguments. In particular, we revisit the various modalities and roles of forensic genetics in the governance of crime in contemporary societies. Additionally, we reflect upon paths for the future of research in the field of the social studies of forensic genetics.
\end{abstract}

Keywords Forensic genetics $\bullet$ Governance of crime $\bullet$ Future investigation

\section{Book Summary}

The main goal of this book is to propose a sociological approach to the role and place of forensic genetics in the governance of crime in contemporary societies. The presented themes are a reaction to the generalized enthusiasm generated around the potential of DNA technologies. We have attempted to explore in depth the complexity inherent in this social phenomenon.

Each chapter highlights a singular dimension of how forensic genetics are used in the governance of crime. As a whole, the different dimensions being analysed point to fundamental reconfigurations in social relationships, as well as to the ethical and legal implications of the use of DNA technologies in criminal justice systems. Among other aspects, the use of DNA technologies has implications for the way societies attribute meaning

(C) The Author(s) 2020 
and classify and conceive the human body, the genetic links between individuals and groups and the physical appearance of individuals and populations. It also has a profound impact on the practices of several professional groups, from forensic geneticists, to police forces, criminal investigators, diverse stakeholders and the citizens. Finally, the use of DNA technologies in the criminal justice system has diverse and deep implications in the way institutions and public policies manage expectations for the governance of crime, namely in terms of police and judicial cooperation initiatives whereby DNA data and information are exchanged to support transnational criminal investigations.

The considerations developed in this book begin by illustrating the role of sociology in the study of the micro/macro and subjective/objective dimensions of the social processes and dynamic generated by the presence of DNA technologies in the criminal justice systems (Chap. 2). Such dimensions provide context, norms and values to the social actions of heterogeneous actors, namely: laboratory technicians, forensic genetics researchers, police forces, judges, prosecutors, attorneys, jurors, professional organizations, supervising entities, non-governmental entities, politicians, criminals, victims and citizens in general. Based upon this polysemic framing, we describe the emergence and consolidation of social studies for forensic genetics. In particular, we explore the scientific and legal controversies that have marked the creation, stabilization and consolidation of the protocols, quality patterns, expert communities and legislation focused on the use of DNA technologies in the criminal justice system. Such an analysis is followed by a summary description of the way several research methods and techniques (document analysis, interviews, surveys, observation, focus groups, among others) have been used in this field of study, while also providing a multifaceted image of this phenomenon.

Subsequently, to contextualize the broader scenarios that transcend the application of forensic genetics in the justice system, we engage in a critical debate about the biological explanations of criminal behaviour. Throughout Chap. 3, we emphasize how it proved to be particularly relevant to trace the field's history, from biological determinism-outlining its severe implications for individuals classified as "born criminals" - until the most recent biogenetic explanations. The current development of epigenetics and neurobiology frame the new discussions about nature versus nurture, fostering new ways to act upon certain social groups considered as risky, even in the absence of any deviant or criminal behaviour. 
The next two chapters of the book frame and describe the way DNA technologies have been used in courts and in the field of criminal investigation. In Chap. 4, we highlight the idiosyncrasies of the various epistemic cultures involved in the chain of custody through which DNA circulates from the crime scene to the courts of law. The risks associated with the high expectations placed upon DNA potential to solve criminal cases are explored in detail. We also analyse the role of media in the dissemination of notions of DNA as an "infallible" technology. Another theme that merits our attention is the creation and expansion of criminal databases containing thousands of DNA profiles, where we also note the ethical and human rights issues stemming from this phenomenon. Finally, Chap. 5 also provides the reader with a brief discussion about Big Data in the context of the growing collection of data in the present information society, more particularly by reflection upon how Big Data can potentially support criminal investigations due to its ability to predict and anticipate risks.

Taking as the starting point the consolidation and expansion of forensic genetics in the governance of crime, in terms of both impact and reach, the last chapters of the book are dedicated to debating the way DNA technologies have proliferated in contemporary societies while finding new frameworks for application on the justice system. One example of those configurations is linked to the growing interoperability between forensic DNA databases, which is the topic of discussion in Chap. 6 .

The interoperability of forensic DNA databases is illustrated by the creation of the Prüm system, which aims to control and surveil irregular mobilities within the European Union by exchanging data transnationally. In this regard, we outline how the transnational exchange of DNA data emerged as a project whose goal was aimed towards overcoming the social and political disparities in the European Union. Nevertheless, it is clear that such a goal of overcoming disparities through technological standardization is nowadays paired with the consolidation of a system of wider social sorting that highlights several geopolitical tensions.

Chapter 7 focuses on the expansion of the use of forensic genetic technologies by discussing the current development of emergent DNA technologies that make it possible to generate intelligence to search for criminal suspects. We explore the implications of the use of particular technologies like familial searching and forensic DNA phenotyping. Such technologies aim to help criminal investigations to place their attention on specific suspect groups, thereby moving forensic genetics from individual identification towards the collectivization of suspicion. In addition, these emerging 
technologies also showcase the co-evolving relation between science, justice and the market. As a result, the governance of data has become the focal point of debates, coexisting and reconfiguring older debates focused upon topics such as genetic privacy, ownership of personal data and data usage consent.

\section{POINTS FOR REFLECTION}

This book shows how, by becoming a tool in service of justice, the application of DNA technologies entails the creation of new configurations able to connect identities, perspectives and risk notions (Lynch, Cole, McNally, \& Jordan, 2008). From the standpoint of risk society theories (Beck, 1944; Giddens, 1990), the mechanisms for social control and management of public trust used by the State are significantly dependent on two vectors: on the one hand, the accumulation, computerization and handling of massive amounts of data about the citizens. In several fields of social life, we can see a proliferation of practices that validate the participation of citizens in technological processes of "identity securitization". Such processes include biosurveillance mechanisms and identity verification/confirmation technologies that use DNA technologies. On the other hand, another vector of the social control mechanisms and management of public trust used by the State regards the technological and scientific innovations applicable to the criminal justice system.

The DNA technologies analysed in this book reveal precisely the acceleration of the reconfiguration of classic control mechanisms. According to several authors (see, e.g., Aas, 2004; Lyon, 2002, 2004; Tsianos \& Kuster, 2016; Van der Ploeg, 2003), it is a matter of configuring knowledge about populations and their respective bodies into a language that can be translated and read by machines (Dodge \& Kitchin, 2004). Such knowledge is also configured as transferable in information patterns that can be organized into movable "packages" by various social control agents, such as criminal investigation institutions.

This new "body ontology" can be seen in the debate about the role of forensic genetics in the governance of crime, according to a principle that upholds the right to privacy, which is closely connected to the configuration of the body's information. We are seeing the emergence of a type of genetic privacy that is no longer linked to intrusion on the individual's body, but to the State's intrusion on the information "stored" on the 
genetic code. A close look into such processes also highlights how the reproduction of inequality and social differentiation is growingly linked to technological control and strengthened by a culture focused on security. Within this context, a part of the population, whether by misfortune, their origin or their behaviour, are excluded as "non-citizens", "failed citizens" or "anti-citizens" (Aas, 2011; Rose, 2000).

Thus, the control of populations using genetic technologies is a governance feature of contemporary societies, made possible by a type of surveillance that doesn't necessarily look for people or behaviours assessed as deviant. Instead, it searches for preexisting exclusion parameters (in a risk containment logic) which are determined by identifiable patterns in the databases-what Roger Clarke (1988) called dataveillance (see also Lyon, 2001). The identification is not limited to the (potential) offender, but also encapsulates groups and identities which, due to their traits, become suspicious to the database. We are referring to "statistical suspects" (Cole \& Lynch, 2006), considered as such for reasons tied to probability incidence and anchored on a discourse that is seemingly uninterested in the ethical/moral connotations of this categorization.

The context and social implications of the uses of genetic technologies in the criminal justice system provide the basis for addressing these technologies as an integral element of "surveillant assemblage" (Haggerty \& Ericson, 2000). The "surveillant assemblage" represents a vast set of interconnected systems and surveillance practices, which is continuously in flux and devoid of a relevant and concrete hierarchy. This "genetic surveillance" therefore organizes a global transformation of State structures and societies around technological and monitoring devices. This way, new concepts of identity and body take shape, as well as a stronger form of citizens' participation and engagement with the ethical and political implications of such technologies.

Consequently, society's organization around increasing flows of information creates new conditions for emancipation by breaking down traditional power structures into a fluid dynamics. At the same time, we can see a reinforcement of the centrality and symbolic power of scientific knowledge, particularly in the field of bioscience. It serves as the foundation stone for new truth-producing regimes, which will simultaneously integrate political power and judicial initiatives in a way that is liable to reinforce the creation of social inequality. 


\section{Tracing New Paths for the Future of Research}

As noted throughout this book, the use of forensic genetics in the governance of crime is a rapidly growing field, whether in terms of the scale of its activity or in the sophistication of the information that is collected, extracted, analysed, worked upon and used. Among the elements developing and changing at an accelerated rate, and which consequently deserve specific studies to explore in depth their social, ethical, legal and political implications, we highlight two phenomena: the geopolitics of DNA and the expansion of commercial information repositories mobilized for criminal investigation purposes.

DNA geopolitics regards the way the different uses and meanings given to DNA vary according to different national contexts. As this book indicates, the DNA databases with the largest size and sophistication are based on the richest, most technologically advanced countries. However, political forces linked to neoliberalism and security-focused ideologies have imposed on countries with less economic and scientific resources, as well as disparate models for regulation, legislation and organization, the obligation to implement forensic DNA databases. Therefore, it has become urgent to understand the different ways that political, social and economic power intervene in the use of forensic genetics for the governance of crime. To that effect, it's necessary to expand the analysis beyond the pioneering and/or more developed countries in terms of forensic genetics, understanding the way underdeveloped countries in the field of forensic genetics perceive DNA technologies' potential and risks.

Finally, the rapid expansion of commercial information repositories developed by private companies represents a sharp dilemma for those responsible for regulatory frameworks and ethical issues. One significant example is the "recreational databases" that try to infer, using DNA, the biogeographical ancestry and/or predisposition towards certain health conditions. In a context where social values and scientific legitimacy are (re)negotiated, recreational genetic databases show a tension between optimism regarding the techno-scientific potential to solve complex criminal cases and the public's distrust about the ethical limits of science and technology. Moreover, the use of such databases in the field of forensics underscores the emergence of new social arenas where police forces, scientists, private companies, the media and the general public actively interact. These social processes create new possibilities in forensic science that are based upon considerations that balance the benefits of identifying criminal 
offenders and the undesirable collateral damage of threatening genetic privacy.

\section{REFERENCES}

Aas, K. F. (2004). From narrative to database: Technological change and penal culture. Punishment \& Society, 6(4), 379-393. https://doi.org/10.1177/ 1462474504046119

Aas, K. F. (2011). "Crimmigrant" bodies and bona fide travelers: Surveillance, citizenship and global governance. Theoretical Criminology, 15(3), 331-346. https://doi.org/10.1177/1362480610396643

Beck, U. (1944). Risk society: Towards a new modernity. London: Sage Publications.

Clarke, R. (1988). Information technology and dataveillance. Communications of the ACM, 31(5), 498-512.

Cole, S., \& Lynch, M. (2006). The social and legal construction of suspects. Annual Review of Law and Social Science, 2, 39-60. https://doi.org/10.1146/ annurev.lawsocsci.2.081805.110001

Dodge, M., \& Kitchin, R. (2004). Codes of life: Identification codes and the machine-readable world. Environment and Planning D: Society and Space, 23, 851-881. https://doi.org/10.1068/d378t

Giddens, A. (1990). The consequences of modernity. Cambridge: Polity Press.

Haggerty, K. D., \& Ericson, R. V. (2000). The surveillant assemblage. The British Journal of Sociology, 51(4), 605-622. https://doi.org/10.1080/00071 310020015280

Lynch, M., Cole, S., McNally, R., \& Jordan, K. (2008). Truth machine: The contentious history of DNA fingerprinting. Chicago: University of Chicago Press.

Lyon, D. (2001). Surveillance society: Monitoring everyday life. Buckingham: Open University Press.

Lyon, D. (2002). Surveillance as social sorting. Hoboken: Taylor \& Francis Ltd. Retrieved from http://public.eblib.com/choice/publicfullrecord.aspx?p= 240591

Lyon, D. (2004). Globalizing surveillance: Comparative and sociological perspectives. International Sociology, 19(2), 135-149. https://doi.org/10.1177/ 0268580904042897

Rose, N. (2000). The biology of culpability: Pathological identity and crime control in a biological culture. Theoretical Criminology, 4(1), 5-34. https://doi. org/10.1177/1362480600004001001

Tsianos, V. S., \& Kuster, B. (2016). Eurodac in times of bigness: The power of Big Data within the emerging European IT agency. Journal of Borderlands Studies, 31(2), 235-249. https://doi.org/10.1080/08865655.2016.1174606 
Van der Ploeg, I. (2003). Biometrics and the body as information: Normative issues of the socio-technical coding of the body. In D. Lyon (Ed.), Surveillance as social sorting: Privacy, risk, and automated discrimination (pp. 57-73). New York: Routledge. Retrieved from http://scholar.google.com/scholar?hl= en\&btnG=Search\&q=intitle:Biometrics, +and+the+body+as+information:+nor mative+issues+of+the+socio-technical+coding+of+the+body\# 0

Open Access This chapter is licensed under the terms of the Creative Commons Attribution 4.0 International License (http://creativecommons.org/licenses/ by $/ 4.0 /$ ), which permits use, sharing, adaptation, distribution and reproduction in any medium or format, as long as you give appropriate credit to the original author(s) and the source, provide a link to the Creative Commons licence and indicate if changes were made.

The images or other third party material in this chapter are included in the chapter's Creative Commons licence, unless indicated otherwise in a credit line to the material. If material is not included in the chapter's Creative Commons licence and your intended use is not permitted by statutory regulation or exceeds the permitted use, you will need to obtain permission directly from the copyright holder.

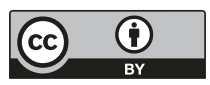




\section{GLOSSARY}

Big Data Technique that aggregates and analyses a huge amount of data, converting it into algorithms, numerically categorized and identified by means of a calculated index, from which information may be extracted.

DNA (deoxyribonucleic acid) Chemical material that makes up each molecule found on chromosomes, carrying the genetic information of each organism. It typically contains different information in different individuals.

DNA evidence Information produced based on DNA technologies that is intended as a probative component to be assessed in a court of criminal justice.

DNA technologies Set of techniques applied to DNA to produce information about a particular biological sample. Encompasses techniques such as DNA profiling, but also emerging technologies such as familial searching and forensic DNA phenotyping.

Familial searching Process through which a DNA profile that does not match any other profile contained in a DNA database is subjected to a new analysis to determine whether there are close matches. If such partial matches exist, it is probable that the profile belongs to a biological relative of the person in the database.

Forensic DNA databases They involve collection, storage and use of DNA profiles from nominated suspects, convicted offenders, victims, volunteers and other persons of interest to criminal investigation work. The aim is to compare profiles of individuals with profiles obtained from crime scene samples.

(C) The Author(s) 2020

H. Machado, R. Granja, Forensic Genetics in the Governance of

Crime, https://doi.org/10.1007/978-981-15-2429-5 
Forensic DNA phenotyping Constellation of techniques that infers physical features, such as eye, skin and hair colour, as well as information about the biogeographic ancestry, from biological materials.

Genetic profile Information extracted from biological samples that aim to define the uniqueness of a given individual from the biological point of view.

Intelligence-led DNA massive screenings/DNA dragnets Procedures that involve collecting DNA samples from "volunteers" who are members of a certain population to search for potential suspects among that population's members by matching samples with those collected from a crime scene/victim.

Match/Hit A "match" or a "hit" are both used equally to describe a correspondence between DNA profiles discovered by a database search at a given moment in time.

Prüm Convention/Prüm Decisions/Prüm system The term Prüm Convention refers to the 2005 Convention involving seven countries, the term Prüm Decisions refers to the Council Decision that established the mandatory nature of transnational data exchange for all EU Member States, and the term Prüm system refers to the actual network of European Union countries exchanging DNA data.

Prüm Step 1 and Step 2 The Prüm System functions in two different steps. Step 1 refers to the moment when a search is made in a national database for a DNA profile retrieved from a crime scene and no match is found; the Prüm Decisions permits the DNA profile reference to be transmitted and searched in other Member States' national databases. A notification is then sent to the original Member State informing it of a match or no match. If a match is identified, Step 2 occurs and further requests for information are processed through the existing police and/ or judicial channels. 